\title{
TERRORISMO DE ESTADO Y MALVINAS: EL MONTAJE DE LA IMPUNIDAD
}

\author{
Maestría en Derechos Humanos \\ Facultad de Ciencias Jurídicas y Sociales UNLP
}

AÑO 2020

Dirección: Mg. Julián Axat

Co-Dirección: Dr. Fabián A. Quintero

Estudiante: Jerónimo Guerrero Iraola jguerreroiraola@gmail.com 


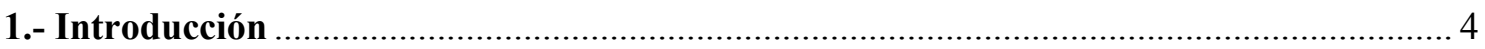

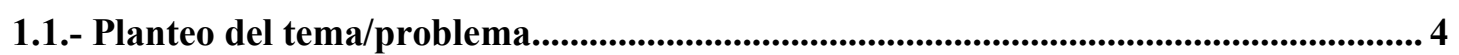

1.2.- Justificación Personal de la Elección....................................................................................... 7

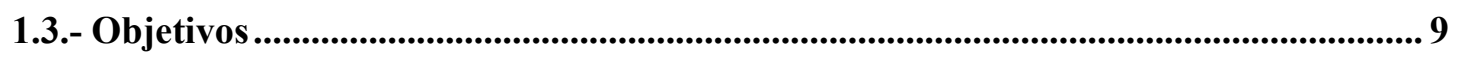

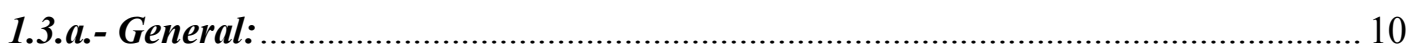

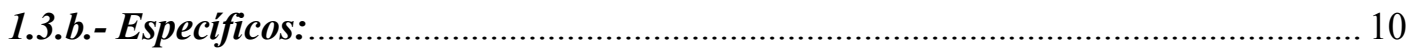

1.4.- Preguntas de investigación ................................................................................. 10

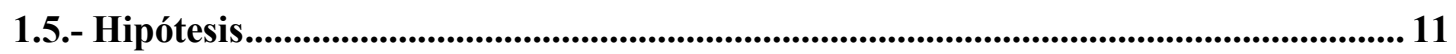

1.6.- Diseño y metodología de la investigación ................................................................................. 11

1.7. Tecnologías de ocultamiento o tecnologías de impunidad: esbozo de un marco

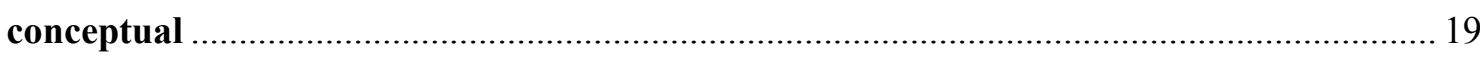

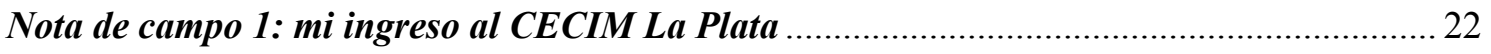

Nota de campo 2: CECIM La Plata, un martes cualquiera ................................................. 24

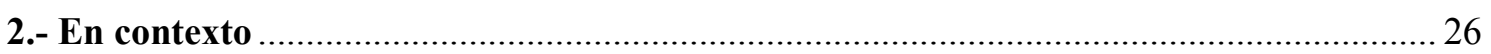

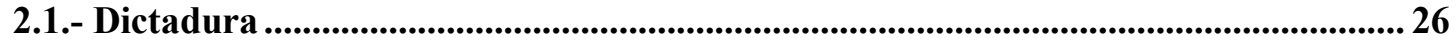

2.2.- Doctrina de la Seguridad Nacional........................................................................................ 29

2.3.- La guerra de Malvinas........................................................................................................... 32

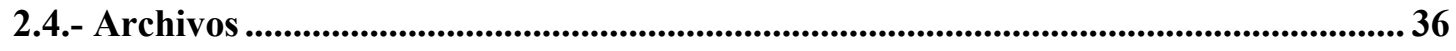

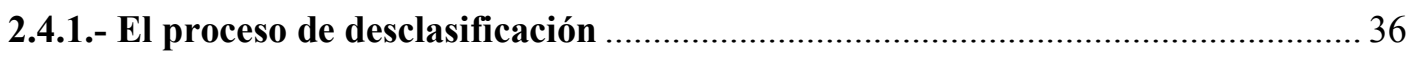

2.4.2.- Comisión de Evaluación de las Operaciones en las Islas Malvinas: Informe

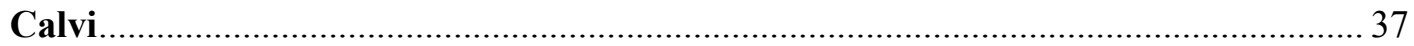

2.4.3.- Informe de la Comisión de Análisis y Evaluación de las Responsabilidades del

Conflicto del Atlántico Sur (CAERCAS): Informe Rattenbach .................................. 38

Nota de campo 3: Hugo Robert rememora la situación del cañón 105. Una mirada a

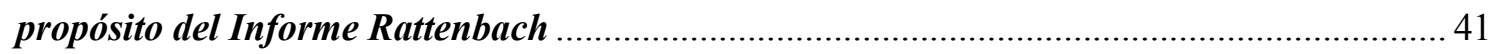

Nota de campo 4: Germán Bonanni y la radio sin pilas, releyendo el Informe Rattenbach ... 43

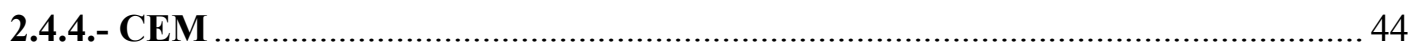

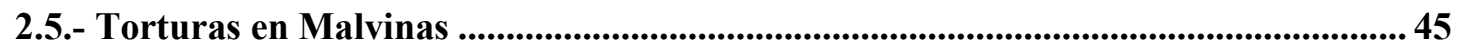


2.5.2.- Las denuncias de Corrientes: el importante rol de "Iluminados por el fuego" $y$ las industrias culturales . 46

2-5-3 Las denuncias de Chaco: la federalización de la causa y su trámite. 47

2.5.4.- El momento de mayor riesgo de la causa. 49

Nota de campo 5: Audiencia en Ushuaia con el Juez Federico Calvete... 53

2.5.5.- Los hechos que se investigan 56

2.6.- El trámite ante la Comisión Interamericana de Derechos Humanos 59

Nota de campo 6: Reunión de trabajo ante la CIDH. 60

2.7.- ¿Qué documentación sobre Malvinas produjeron las Fuerzas Armadas? 61

2.7.1.- Archivos desclasificados relativos al conflicto bélico del Atlántico Sur: actas de recepción 64

2.8.- Testimonios. El fin de la guerra y la imposición de silencio. 78

Nota de campo 7: “Cecimito”, un soldado estaqueado en la Corte Suprema. 87

2.9.- Las primeras 4 indagatorias. Los primeros 4 procesamientos. El reconocimiento de las tecnologías de la impunidad por parte del Estado 89

2.10.- Artículos periodísticos y amedrentamiento. La urdimbre de la impunidad .... 92

Nota de campo 8: Audiencia en Comodoro, el episodio del aeropuerto con Ribas 98

2.11.- Discurso del Jefe del Estado Mayor del Ejército en el marco de la conmemoración del Día del Ejército 2019 101

Nota de campo 9: Audiencia en Río Grande con la Jueza Mariel Borrutto 102

3.- Análisis

3.1.- Sinopsis: Diagrama de logística probatoria basada en evidencia para la hipótesis original 115

Nota de campo 10: denuncia $\mathbf{N A}$

4.- Conclusiones

5.- Referencias 
Agradecimientos:

A Agus, Simón y Helena

A Kiko y Marthita

A Delia (por su lectura atenta) y a Sergio

Al CECIM La Plata

A Laurentina

A Beto

A Carlitos (por su lectura atenta)

Agradecimiento especial:

A mis Directores, Julián Axat y Fabián Quintero, por su tiempo, dedicación y apoyo

A la Universidad Nacional de La Plata 


\title{
1.- Introducción
}

\section{1.- Planteo del tema/problema}

\author{
“Una nación que se niegue a señalar qué es \\ lo que sucedió con sus habitantes o con una \\ parte de su población, no sólo es un estado \\ inmoral, sino que tampoco puede ser \\ considerado democrático y respetuoso de los \\ derechos humanos. De allí que la \\ exploración de la verdad histórica constituye \\ una obligación del Estado, y un derecho de \\ la víctima, del familiar y de la sociedad que \\ tienen derecho a conocer y contar su \\ historia”.
} (Ramos Padilla, 2011: 117)

La presente investigación busca aportar elementos para la reescritura del hecho bélico que protagonizó la República Argentina con el Reino Unido de la Gran Bretaña e Irlanda del Norte en el año 1982. El proceso que comenzó con la Operación Rosario ${ }^{1}$ y perduró una vez finalizado el conflicto armado implicó, en los hechos, la consolidación de un relato histórico en el que se omiten distintas violaciones a los derechos humanos cometidas por Oficiales, Suboficiales, y diversos agentes del Estado ubicados en distintas

1 “...el 2 de abril de 1982, en una operación conjunta de las FF.AA. -denominada "Operación Rosario”- al mando del Almirante Carlos Busser, las tropas argentinas desembarcan en la Isla Soledad en las proximidades de Puerto Stanley (Puerto Argentino) logrando la rendición de la guarnición militar británica destacada en Malvinas (compuesta por unos 70 efectivos británicos y alrededor de 25 milicianos de las Falkland Islands Defence Forces).” (Bertaccini, 2012:36) 
posiciones de la cadena de mando de las Fuerzas Armadas argentinas en perjuicio de los soldados conscriptos ${ }^{2}$.

De esta forma, se asistió a la emergencia de diversos discursos de claro corte desmalvinizador, intentos de anudamiento de sentido, que ataban los hechos y sujetos sólo a la noción de guerra, en tanto gesta patriótica, suprimiendo así los distintos ribetes que, por ejemplo, invitan a pensar el suceso en un contexto en que imperaba, en nuestra región, la llamada "doctrina de seguridad nacional", y que se cimentaba entre otras cosas, en una caracterización de las juventudes que, en territorio continental, sirvió como plafón para el despliegue de un Plan Sistemático de Exterminio³.

\begin{abstract}
La idea de "desmalvinizar" suele atribuirse al intelectual francés Alain Rouquié. En una entrevista realizada por el recordado Osvaldo Soriano para la revista Humor en marzo de 1983, el académico manifestó que quienes pretendan evitar "que los militares vuelvan al poder tienen que dedicarse a desmalvinizar la vida argentina. Esto es muy importante: desmalvinizar, porque para los militares las Malvinas serán siempre la oportunidad de recordar su existencia, su función, y un dia, de rehabilitarse. Intentarán hacer olvidar la guerra sucia contra la subversión y harán saber que ellos tuvieron una función evidente y manifiesta que es la defensa de la soberanía nacional" 4 (Pestanha).
\end{abstract}

Sin embargo, frente a la vocación de abordar y dar tratamiento a las mentadas violaciones a los derechos humanos en territorio insular argentino ${ }^{5}$, irrumpen cuestiones de orden conceptual/inteligible que dificultan la misión relativa a la caracterización de los

\footnotetext{
${ }^{2}$ Al hablar de soldados conscriptos de hace referencia a aquellos jóvenes de entre 19 y 20 años que eran incorporados, durante la Ley de Servicio Militar Obligatorio (Ley 17.531) que disponía:

Artículo $1^{\circ}$ - El servicio militar es la obligación que cumplen los argentinos varones y mujeres nativos, por opción o naturalizados, incorporados a las fuerzas armadas por el Poder ejecutivo Nacional conforme a los establecido en el artículo 21 de la Constitución Nacional y leyes contribuyentes.

La obligatoriedad del Servicio Militar quedó derogada con la sanción de la Ley 24.429 B.O.10/1/1995.

${ }^{3}$ Probado en el marco de la causa 13/1984 en la que se enjuició y condenó a los Comandantes militares, artífices de la dictadura cívico militar que, en la República Argentina, irrumpió en el poder en el período 1976/1983.

${ }^{4}$ Hace referencia a Revista Humor $N^{\circ} 105$, Reportaje de Osvaldo Soriano, marzo de 1983.

${ }^{5}$ Islas Malvinas, Georgias y Sandwich del Sur.
} 
hechos denunciados ${ }^{6}$. En este punto, aflora la necesidad de realizar una aproximación al hecho bélico a la luz de la documentación desclasificada mediante decreto del Poder Ejecutivo Nacional N 503/2015 que dispuso relevar de la clasificación de seguridad toda aquella documentación de carácter no público vinculada al desarrollo del conflicto bélico del Atlántico Sur obrante en los Archivos de las Fuerzas Armadas; como también las distintas denuncias realizadas por soldados conscriptos, documentación de carácter no oficial, archivos fílmicos, las consideraciones y evaluaciones contenidas en el Informe de la Comisión de Análisis y Evaluación de las Responsabilidades del Conflicto del Atlántico Sur (CAERCAS), conocido como Informe Rattenbach ${ }^{7}$.

Como se verá en el desarrollo de la presente investigación, de la lectura de la documentación desclasificada surgen elementos centrales para reconstruir la tecnología política/burocrática implementada por las Fuerzas Armadas en aras de lograr enterrar los hechos ominosos denunciados por cientos de soldados conscriptos, e instaurar dispositivos idóneos para continuar abonando la idea de "gesta patriótica" ante la opinión pública. Resulta imprescindible remarcar que los elementos que han emergido a superficie se exhiben como una gran posibilidad para caracterizar las acciones desplegadas por la Dictadura para el logro de tales fines, que han redundando en que, a 38 años de la finalización de la guerra, aún no existan avances significativos en la investigación y eventual juzgamiento de los hechos.

Así, frente a la necesidad de las víctimas de arribar a la verdad y la justicia, surgió con inusitada fuerza la maquinaria de la impunidad, cristalizada en el culto al silencio, en la "clasificación" de documentos como herramienta jurídica, en las sensaciones e idearios introyectados en los sujetos, en cada acción de inteligencia desplegada para contener las filtraciones. Desde el diseño de los Centros de Recuperación de Ex Prisioneros de Guerra (CREPG), o de los Centros de Apoyo a la Recuperación Integral (CARI) y de los Centros de Recuperación del Personal de la Fuerza (CRPF), la implementación de las actas de recepción, las órdenes de comunicación interna/externa, hasta el trabajo desplegado sobre

\footnotetext{
${ }^{6}$ Actualmente investigados en el marco de una causa que tramita ante el Juzgado Federal de Río Grande, Tierra del Fuego, Argentina, en la que se han radicado más de 120 denuncias por torturas y otros tratos crueles, inhumanos y/o degradantes.

${ }^{7}$ Tanto el fondo documental desclasificado mediante Decreto 503/2015, como el Informe Rattenbach, serán abordados en la presente investigación.
} 
cada una de las víctimas, el material que se analizará a lo largo de la presente investigación permite deconstruir las tecnologías del ocultamiento ${ }^{8}$.

El término tecnologías del ocultamiento, o tecnologías de la impunidad (en la investigación son utilizados como sinónimos) son un constructo teórico que surgió ante la necesidad de condensar, en dichos sintagmas la trama burocrático/administrativa/conductual/corporativa desplegada por las Fuerzas Armadas durante la guerra de Malvinas y, sobre todo, una vez finalizado el conflicto, con el objetivo de silenciar a los soldados conscriptos que habían padecido, en forma consecutiva, las falencias propias de la organización de la "aventura militar" (Informe Rattenbach), y las torturas, vejámenes y malos tratos propinados por sus superiores.

Frente a ello, los hechos/sujetos que se reconstruirán, no han sido investigados por el Estado argentino, merced a las dificultades que hasta ahora se han constatado en materia de acceso a la información; lo que en la práctica se traduce en sistemáticas violaciones a los derechos humanos vía revictimización, en virtud de la flagrante conculcación del derecho/garantía de acceso a la justicia y el derecho a la Verdad ${ }^{9}$. Ello implica un desafío adicional: la humanización de la investigación, es decir, ejercer una debida vigilancia epistemológica (Blanco, 2010) relativa a la exteriorización de las situaciones que han vivenciado los colectivos de ex soldados conscriptos combatientes en Malvinas en los últimos 30 años.

\section{2.- Justificación Personal de la Elección}

El tema de la investigación se encuentra ligado en forma íntima a mi desarrollo profesional, concretamente, a la abogacía. Hacia fines del año 2011 fui convocado a

\footnotetext{
${ }^{8}$ Todo aquello a lo que se hace referencia en el párrafo será abordado en la presente investigación.

${ }^{9}$ Artículos 8 y 25 en relación con el artículo $1^{\circ}$ de la Convención Americana de Derechos Humanos, como así también la conculcación de los artículos XVIII y XXIV de la Declaración Americana de los Derechos y Deberes del Hombre (en adelante "Declaración Americana"), y del Derecho a la Verdad, íntimamente relacionado a los artículos mencionados.

El derecho a la Verdad ha sido caracterizado como aquel que "asiste a las víctimas de violaciones manifiestas a los derechos humanos y violaciones graves al derecho internacional humanitario, así como a sus familias y a la sociedad en su conjunto, de conocer la verdad sobre tales violaciones de la manera más completa posible, en particular la identidad de los autores y las causas, los hechos y las circunstancias en que se produjeron." (CIDH, 2014)
} 
formar parte -en carácter de coordinador- del equipo jurídico del Centro de Ex Combatientes Islas Malvinas La Plata (CECIM).

En ese entonces, la causa en que se investigan las torturas y graves violaciones a los derechos humanos pendía de un delgado filamento. El expediente, iniciado en 2006 con la denuncia de Rubén Darío Gleriano, víctima, al que un año después se sumaron una veintena de denuncias recopiladas por el entonces Subsecretario de Derechos Humanos de la Provincia de Corrientes, Pablo Andrés Vassel, había recibido un duro revés en el Tribunal Nacional de Casación.

Así, tuvimos que diseñar, junto a compañeros y compañeras, una estrategia ante la Corte Suprema de Justicia de la Nación. Frente a ello, recuerdo que una de las cosas que más llamó mi atención fue el hecho de que, varias décadas después de finalizada la guerra de Malvinas, no se pudiese avanzar con contundencia, aún con la constatación de que se estaban investigando más de un centenar de casos.

Había en dicha urdimbre, varias líneas férreas cuyo propósito (aparentemente manifiesto) era la consagración del oscurantismo y el silencio. Claro que la dimensión procesal y la vorágine que propone batallar nada menos que con las estructuras de las Fuerzas Armadas no brindaban mucho espacio para la indagación profunda.

En la actualidad continúo al frente, junto a mi colega Laurentina Alonso, de la representación del organismo. La diferencia entre aquel lejano 2011 y este presente radica en haber atravesado las cursadas de la Maestría en Derechos Humanos de la Facultad de Ciencias Jurídicas y Sociales. Tal vez la formalidad de tener que afrontar la realización de una tesis, haya sido la mejor "excusa" para abordar de una vez por todas lo que para mí supone el nodo crítico de esta causa: tecnologías de la impunidad o tecnologías del ocultamiento.

Existe, como una derivación de esta dimensión, una Petición en trámite ante la Comisión Interamericana de Derechos Humanos, en la que hemos solicitado se declare la responsabilidad del Estado argentino por la negación de los derechos/garantías (merced a su instrumentalidad) de acceso a la Justicia y a la tutela judicial efectiva.

Aquí, mientras intento dar forma a esta investigación, se han logrado los primeros cuatro procesamientos, en el marco de unas actuaciones en las que se ha denunciado a 95 miembros de las Fuerzas Armadas por 105 casos de torturas y/o graves violaciones a los 
derechos humanos. En simultáneo, en nuestro carácter de querellantes, representamos a 120 denunciantes que se encuentran diseminados a lo largo y ancho del país.

En estos 13 años de vida de la causa, hemos sido blanco de amedrentamientos por parte de diversos integrantes de las Fuerzas Armadas, y de algunos medios de comunicación que, como se verá, siguen inmersos en las lógicas del silenciamiento y el avasallamiento de derechos, en este caso, a la Verdad y la Justicia.

Esta investigación se gesta en caliente. Sí, al fragor de los hechos, sentimientos, sensaciones, frustraciones y algarabías de quien cumple el doble rol de ser investigador y abogado de las víctimas, a través de la representación de la querella que encabeza un organismo. Frente a ello, resulta indispensable trazar una sólida vigilancia epistemológica ${ }^{10}$. La misma está dada por el deseo de que este trabajo pueda ser utilizado como material probatorio, y también como pieza académica capaz de contextualizar la presunta comisión de graves violaciones a los derechos humanos investigadas en el expediente judicial.

\section{3.- Objetivos}

A los efectos de situar la lupa sobre un aspecto específico de un hecho bélico que marcó un hito en la historia de la República Argentina, he fijado los siguientes objetivos:

\footnotetext{
${ }^{10}$ Cecilia Blanco (2010) plantea que la vigilancia epistemológica como aquella actividad que ejerce el investigador cuando logra reconoce la clara separación entre el discurso científico y la opinión común y aplica, para evitar caer en la sociología espontánea, técnicas de objetivación (tales como la crítica léxica y lexicológica del lenguaje o el uso de la estadística para desconcertar las primeras impresiones), así como también una estrategia de construcción teórica del objeto de estudio y otras estrategias teóricas de decisión sobre los métodos y técnicas a utilizar. La vigilancia epistemológica resulta en una actitud que el investigador debe tomar a lo largo de todo el proceso de investigación, y responde, en definitiva, a los actos epistemológicos del procedimiento científico: ruptura, construcción y comprobación.

Y agrega: El concepto de "Vigilancia Epistemológica" (Bourdieu, Chamboredon y Passeron, 2004: 11-24) tiene relación con la necesidad imperiosa en Ciencias Sociales de restituir a los conceptos teóricos de su fuerza heurística. Por otra parte, remite a la noción de que el investigador debe mantener coherencia teórica respecto de la o las líneas de pensamiento que ha elegido para realizar una investigación. La coherencia teórica es lo que le va a permitir luego reconocer cuáles son los errores que comete dentro del proceso de investigación y encontrar, dentro del marco teórico conceptual elaborado, los mecanismos metodológicos para superar los obstáculos presentados. (Blanco, 2010)
} 


\section{3.a.- General:}

Aportar elementos para la reescritura del hecho bélico -que protagonizó la República Argentina con el Reino Unido de la Gran Bretaña e Irlanda del Norte en el año 1982- definiendo las tecnologías de la impunidad/del ocultamiento que sirven para consolidar el relato construido por sectores involucrados que omite violaciones a los derechos humanos cometidas por Oficiales, Suboficiales, y diversos agentes del Estado ubicados en distintas posiciones de la cadena de mando de las Fuerzas Armadas argentinas en perjuicio de los soldados conscriptos.

\section{3.b.- Específicos:}

1.3.a.- Reconstruir el montaje del dispositivo de impunidad instaurado por las Fuerzas Armadas durante/después del conflicto bélico entre la República Argentina y el Reino Unido;

1.3.b.- Abordar la guerra de Malvinas (1982) a la luz de las violaciones a los derechos humanos cometidas en el archipiélago;

1.3.c.- Sistematizar la información emergente de las diversas fuentes documentales, testimoniales y bibliográficas.

Y los objetivos específicos que se consignan a continuación:

1.3.d.- Describir los mecanismos especificos erigidos en procura de silenciar a las víctimas de violaciones a los derechos humanos;

1.3.e.- Caracterizar los dispositivos de comunicación exógena dirigidos a la opinión pública;

\section{4.- Preguntas de investigación}

Las preguntas que guiaron la presente investigación han sido: 
¿Cómo instrumentaron las Fuerzas Armadas la tecnología político/burocrática de impunidad durante y después de la guerra de Malvinas?

¿Qué dispositivos se utilizaron para el montaje de dichas acciones?

¿Cuál o cuáles eran los objetivos perseguidos por las Fuerzas Armadas al momento de establecer la mentada organización?

¿Qué relevancia detentan los documentos desclasificados mediante Decreto $503 / 2015 ?$

\section{5.- Hipótesis}

Las Fuerzas Armadas instrumentaron, durante y después del hecho bélico que protagonizó la República Argentina con el Reino Unido, un dispositivo político/burocrático ${ }^{11}$ que garantizara dejar impunes las graves violaciones a los derechos humanos cometidas en perjuicio de los soldados conscriptos, y construir ante la opinión pública el relato de la guerra en tanto "gesta heroica".

Estos mecanismos serán nombrados en forma indistinta como tecnologías de la impunidad o tecnologías del ocultamiento.

\section{6.- Diseño y metodología de la investigación}

La presente investigación, en la que se aborda Malvinas en clave de derechos humanos, me llevó a tomar decisiones acerca del material a relevar, y las consecuentes opciones metodológicas a emplear. La primera fue tener que acotar el universo de los materiales.

11 Como se ha manifestado, el término hace referencia a la trama burocrático/administrativa/conductual/corporativa desplegada por las Fuerzas Armadas durante la guerra de Malvinas y, sobre todo, una vez finalizado el conflicto, con el objetivo de silenciar a los soldados conscriptos que habían padecido, en forma consecutiva, las falencias propias de la organización de la "aventura militar" (Informe Rattenbach), y las torturas, vejámenes y malos tratos propinados por sus superiores (obrantes en testimonios y en archivos que documentan los mismos, y que han sido desclasificados mediante Decreto 503/2015).. 
Opté por la documentación desclasificada mediante decreto del Poder Ejecutivo Nacional $\mathrm{N}^{\circ}$ 503/2015 que dispuso relevar de la clasificación de seguridad toda aquella documentación de carácter no público vinculada al desarrollo del conflicto bélico del Atlántico Sur obrante en los Archivos de las Fuerzas Armadas; y también por las distintas denuncias realizadas por soldados conscriptos. A su vez, el marco contextual pudo ser reconstruido a instancias del Informe Rattenbach, desclasificado en el año 2012 mediante decreto 200/2012.

Emergen debates metodológicos entre tradiciones relacionadas con la hermenéutica documental y con la etnografía. Ambas dimensiones se encuentran presentes, en diálogo y tensión. En relación al análisis de documentos. Como afirma Ahmed (2010), la investigación documental constituye un elemento básico en la investigación social desde sus inicios. El autor (2010) remarca la especial importancia de los mismos para el etnógrafo, ya que proporcionan una "veta rica para el análisis" (Hammersley y Atkinson, 1995: 173, en Ahmed, 2010).

La posibilidad de encontrarme, por mi labor profesional, frente a documentos oficiales, constituyó una oportunidad única al momento de confeccionar el corpus a analizar. Los mismos son productos socialmente situados (Scott, 1990:34 en Ahmed, 2010). Scott (1990, en Ahmed 2010), ha formulado diversos criterios de calidad para el manejo de fuentes documentales. Los mismos, son; autenticidad, credibilidad, representatividad y significado (Scott, 1990, en Ahmed, 2010).

La autenticidad hace referencia a la fuente de la que han emergido los documentos y lo genuino de la evidencia que aportan (Scott, 1990, en Ahmed, 2010). En lo que concierne a la credibilidad, el autor apunta a que la evidencia que arroja es o no típica de su tipo (Scott, 1990, en Ahmed, 2010). A su vez, la credibilidad es un atributo orientado a observar si la evidencia es o no representativa de la totalidad de los documentos que componen el fondo documental (Scott, 1990, en Ahmed, 2010). Por último, el significado debe arrojar si la evidencia resulta clara y comprensible (Scott, 1990, en Ahmed, 2010).

Una vez verificados los atributos a los que hace referencia Scott (1990, en Ahmed 2010), el interrogante tuvo que ver con el modo en los mismos debían ser extractados, dispuestos. ¿Cómo hacerlos dialogar? ¿Cómo hacer que los mismos dieran respuesta a muchos de los interrogantes que surgieron, en primer término, en la labor profesional, y 
que ahora se trasladan a la presente investigación? Marshall y Rossman (1995: 111, en Ahmed, 2010), afirman que el análisis de datos es el proceso de traer orden, estructura y significado a la masa de datos recopilados.

En consonancia con lo expuesto, Miles y Huberman (1994, en Ahmed, 2010) han abordado y descripto el análisis de datos, y han puntualizado que el mismo está dirigido a rastrar relaciones legales y estables entre fenómenos sociales, al develar regularidades y secuencias que vinculan a los mismos. Así, puntualizan tres componentes principales del trabajo con datos.

El primer objetivo, tiene que ver con la reducción de datos sin que ello suponga una disipación o pérdida significativa de información (Miles y Huberman 1994, en Ahmed, 2010). Tesch (1990, en Ahmed 2010) llamó a este proceso descontextualización y recontextualización. El objetivo final, tras el "desarme" del acervo documental, es la aparición de una imagen amplia y consolidada (Ahmed, 2010). Como se ha puntualizado, esta instancia ha sido nodal. La cantidad y calidad de información emergente tras el proceso de desclasificación de archivos relativos al conflicto bélico del Atlántico Sur implicó avanzar con decisiones concretas. La reducción del fondo documental a las piezas que se exhiben en la presente investigación ha sido una dimensión central de la labor investigativa.

Luego, sobreviene una etapa intermedia, que ocurre a través de la codificación y la memoria, y actividades asociadas, como encontrar temas, grupos y patrones (Bogdan \& Biklen, 1992, en Ahmed, 2010). Aquí es importante remarcar cómo, órdenes, directivas, anexos, instrucciones, informes, que en principio fueron gestado en distintos ámbitos de las Fuerzas Armadas dialogan, siguen un patrón. Ello se ve una vez reordenadas, dispuestas y presentadas, y tamizadas con los testimonios de los exsoldados conscriptos combatientes en Malvinas.

Con posterioridad, las etapas finales se dan a instancias de la debida conceptualización y la explicación. En efecto, el desarrollo de conceptos abstractos es una forma de reducir los datos (Ahmed, 2010). La labor de reducir y mostrar datos ayuda en la tarea de trazar conclusiones. Si bien las mismas se modelan luego de la reducción y visualización de documentos, en los hechos se extraen en forma concurrente. Por lo tanto, las incipientes conclusiones pueden ser apreciadas al principio del análisis, en simultáneo 
con la presentación de la información, pese a que en dicho momento pueden ser vagas o mal formadas. Las mismas se apreciarán con vigor al momento de hilvanar y analizar todos los datos (Ahmed, 2010).

Con respecto a los documentos, Fernando López Noguero (2002), al abordar los métodos de análisis posibles para ellos, sostiene:

\begin{abstract}
son muy variados (...), los hay intensivos, que estudian con detenimiento algunos documentos, y los extensivos, que recurren a una gran cantidad y se suelen preocupar por los aspectos cuantitativos. Algunos métodos se centran en el análisis externo. Este enfoque procura colocar al documento en su contexto, o sea, en el conjunto de circunstancias entre las- que surgió y que permiten explicarlo. Así, se constituyen en necesarios para interpretar los hechos y estudiar, también, los factores sociales, políticos, económicos, culturales, científicos, tecnológicos, etc.; descubriendo asi el valor del mensaje y el impacto que puede ejercer (López Noguero, 2002: 172)
\end{abstract}

A los fines de este trabajo, opté por el método intensivo, es decir, análisis profundo de una selección de los documentos y no la totalidad; y el de análisis externo de acuerdo con las consideraciones del autor citadas.

Por su parte, dentro de las aludidas tensiones metodológicas, que mucho tienen que ver con el aludido análisis externo, surgió el interrogante en torno a la posibilidad de realizar una etnografía en los archivos, y no desde los archivos (Zabala, 2012: 268).

\footnotetext{
El hecho etnográfico es una selección observada, leída e interpretada por el antropólogo (Guber, 1991; Peirano, 1991), por lo tanto la etnografía no es una técnica, como lo formula Bosa (2010), sino la integración y la puesta en diálogo entre los datos y la teoría (Guber, 1991: 62-63). (Zabala, 2012: 270)
}

La investigación apunta a reconstruir cómo los actores en juego, a saber, miembros de las Fuerzas Armadas, exsoldados conscriptos combatientes en Malvinas, entre otros, 
configuraron el marco significativo de sus prácticas y nociones (Zabala, 2012). Por su parte, como apunta Zabala (2012) los archivos no sólo constituyen algo del pasado, sino que también están normatizados y normalizados por una lógica estatal. En este caso su clasificación, su posterior desclasificación, o las lógicas de los equipos que han trabajado en su sistematización e indexación, entre otras.

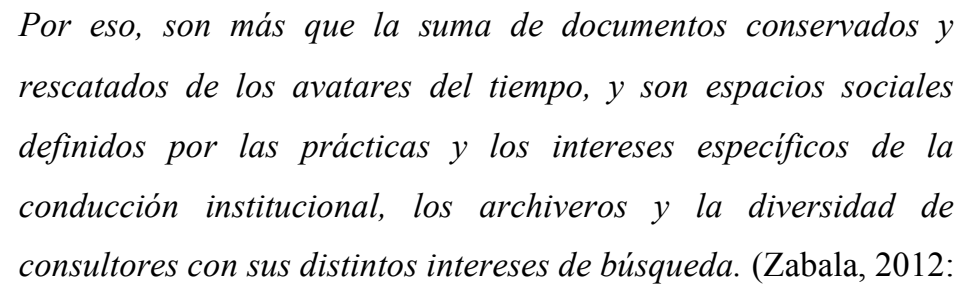

Los archivos en sí mismos denotan una semiología potente para el curso de la presente investigación. Su clasificación merced a la alegada seguridad nacional, fue (es) también uno de los hitos que hacen a la trama de configuración de las tecnologías de olvido (o tecnologías de impunidad). Por ello, mi campo son los archivos (Zabala, 2012: 280), porque hay pasado, en aquel diálogo y tensión entre hechos, contexto, sucesos y actores, pero hay también presente y futuro, en las dificultades que su tratamiento por parte del Estado han arrojado para echar luz en el proceso de Verdad y Justicia.

En segundo término, en lo que respecta al relevamiento del material, la selección se inscribe en la tradición del paradigma cualitativo/etnográfico, dado que implica un diálogo, análisis, y desarrollo a partir de los testimonios obrantes en la causa de los soldados conscriptos y que, en algunos casos, fueron víctimas de violaciones a los derechos fundamentales.

Para el análisis de los testimonios opté por el método biográfico, al comprender que “...las experiencias individuales, antes consideradas terreno exclusivo de la excepción, comenzaron a ser pensadas como un objeto científico válido” (Perren, 2012).

Szczepanski (1979), plantea que el método biográfico es una forma de investigación en la que para la solución de un problema se recogen exclusivamente materiales que contienen manifestaciones humanas acerca de su participación en sucesos y en acontecimientos semejantes a procesos. En la base de tales relatos se ofrece una 
descripción de estos procesos y se sientan hipótesis encaminadas a explicarlos. El método permite localizar actitudes y experiencias del individuo en su proceso vital y observar la trama social y los diversos condicionamientos con respecto al medio. Por otro lado, Mitoma (2010) entiende que la utilidad del método biográfico se basa en su interdisciplinariedad inherente, su atención a las dimensiones físicas, emocionales e intelectuales de la experiencia humana, y su compromiso con la fidelidad histórica. Lo considera indispensable en el análisis desde una perspectiva de Derechos Humanos, ya que, como estudio de un sujeto humano, la biografía puede describir con precisión histórica y especificidad empírica los procesos por los cuales un individuo en particular se constituyó como persona.

Y al analizar los testimonios en conjunto, comprueba lo apropiado de "reconstruir las experiencias personales que conectan entre sí 'yos' individuales que interactúan en familias, grupos e instituciones" (Perren, 2012: 1-2).

El método biográfico propone "recuperar la voz de los marginados, sean estos integrantes de clases subalternas o bien grupos minoritarios", y conlleva un "afán de democratizar la práctica científica; algo que no deja de ser el efecto necesario de su matriz epistemológica: se trata de un conocimiento que se construye" (Perren, 2012: 3-4). Con respecto a esta "construcción, sostiene Ferrarotti "El observador está radicalmente implicado en su investigación, esto es, en el campo de su objeto investigado, (por lo tanto) el conocimiento no tiene al 'otro'como ser objeto: por el contrario, se trataría de la interacción inextricable y recíproca existente entre observador y observado. Se trataría de un conocimiento mutuamente compartido, basado en la intersubjetividad de la interacción, un conocimiento más profundo y objetivo, cuanto más íntegra e íntimamente subjetivo" (Ferrarotti, 1981: 20). Teniendo en cuenta estas características del método, se visualizó lo pertinente de su aplicación para alcanzar los objetivos de esta investigación.

De la lectura minuciosa de los testimonios, surge clara la relación entre la subjetividad de sus enunciadores y procesos sociales de mayor alcance, de lo que se desprenden las dos perspectivas vigentes con respecto al enfoque biográfico: la etnosociológica - que intenta acceder a través de los relatos a las relaciones, normas y procesos que estructuran la vida social - y la hermenéutica, que consiste en el descubrimiento de los significados que transmiten las personas en las narraciones y - a través de ellos - las escalas de valores que organizan el accionar de los individuos (Perren, 2012: 14). Ambas perspectivas resultaron aplicables para el propósito de este 
trabajo. El enfoque también presenta la fortaleza de "no constituir una premisa desde la cual deducir (necesariamente) hipótesis a ser verificadas en la investigación. Por el contrario, su propósito es estructurar campos de investigación" (Saltalamacchia, 1992: 9).

Desde que comencé a investigar el tema Malvinas observé que constituía un problema social insuficientemente analizado: la bibliografía recorrida generalmente aborda el tema desde el ángulo que decidió darle la historiografía "oficial”, sin ahondar en las relaciones entre actores. Dice Sarabia que “...una vida, una biografía, por consiguiente, se construye entre personas y se sostiene en una estructura social" (Sarabia, 1986: 173). Traté en función de esta afirmación de ver qué otros actores y estructuras sociales surgían como importantes en dichos testimonios.

En sintonía con las apreciaciones de Sarabia (1986) acerca de los usos de la historia de vida, las que cito en este trabajo serán utilizadas de los dos modos que el autor propone, y no son excluyentes: como ilustración a veces, como fundamentación de hipótesis otras.

Saltalamacchia al hacer referencia a la relación existente entre individuo y sociedad, parte de la premisa básica del marxismo de que el hombre es un conjunto de relaciones sociales, al analizar la discusión sociológica.

el grado de existencia en 'lo real' de categorías colectivas tales como 'clase', 'estado', etc. Negar la importancia analítica de ese tipo de conceptos es tan falso como atribuirles una existencia independiente de los individuos de los cuales esas colectividades toman existencia corpórea (Saltalamacchia, 1992: 8)

También sostiene que:

Producción y ruptura del orden que unifica las comunidades son dos procesos permanentes y esa dicotomía me sirve en el trabajo para clasificar los determinantes sociales de la conducta individual en dos grupos: aquellos que contribuyen primordialmente a la unificación de la formación social y aquellos otros que fundamentalmente contribuyen a su disgregación (Saltalamacchia, 1992: 9) 
Aunque sé que la objetivación (De la Torre, 1997) es una utopía, considero tener presente lo señalado por Perren (2012) acerca de tratar de construir un conocimiento "que resulta de una interacción entre observador y observado; es decir, la evidencia no preexiste al acto comunicativo (Perren, 2012).

\footnotetext{
La imagen de un científico trabajando en su computadora sobre datos 'dados' muta, para el caso del método biográfico, en un taller donde investigador e investigado trabajan de forma conjunta y en igualdad de condiciones" (Perren, 2012: 4)
}

De esta forma, como se ha puntualizado al momento de trazar la justificación personal de la elección del tema, hace más de ocho años que mantengo un trato cotidiano y fluido con los protagonistas, muchos de ellos víctimas de las graves violaciones a los derechos humanos que se expondrán en la presente investigación. Ello me ha llevado a contar con un ponderador de los testimonios, saber qué y cómo piensan, o cómo se han sentido no sólo durante el desarrollo de las acciones bélicas y el largo período posterior donde continuó la Dictadura del autodenominado Proceso de Reorganización Nacional, sino también en las distintas etapas vivenciadas desde el retorno de la democracia en el año 1983.

En este punto he tomado la decisión de intercalar notas de campo. Experiencias, anécdotas, situaciones, vivencias o apreciaciones relativas a mi participación en el CECIM La Plata, y las diversas intervenciones jurídicas y/o políticas. Las mismas pretenden ser un hilo conductor, o bien digresiones que, entiendo, servirán para contextualizar la investigación. Las mismas no se encuentran ordenadas cronológicamente, ni continúan la numeración de los capítulos o subsecciones de la investigación. Apuntan a dar un marco semántico, a proponer otra lectura posible, un abordaje experiencial por fuera, o yuxtapuesto de la rigurosidad académica.

Dicha dimensión etnográfica, que detenta un carácter de participación al interior del colectivo, está presente a modo de base que da soporte al diseño metodológico. En 
este proceso de integración entre la mirada de la historiografía oficial ${ }^{12}$ sobre el conflicto de Malvinas, y la de la que emerge de los testimonios de los ex combatientes, las historias de vida son "capaces de responder no sólo a nuestras preguntas iniciales, sino de cuestionarlas y plantear nuevos interrogantes que enriquecieron el propio proceso de investigación” (Sapriza, en Lulle, Vargas y Lucero, 1998: 51).

Luego de haber seleccionado el corpus de testimonios oficiales, que obran como denuncia en el marco del expediente 1.777/07, y tras constatar que los mismos aportaban información similar, entendí que la muestra se encontraba saturada. Pueden abordarse 10, 15 o 120 testimonios (denuncias) que el resultado será el mismo. Todos quienes han testimoniado en el marco de la causa judicial, refieren algún comentario, una orden, la firma de un documento cuya única finalidad era obligarlos a guardar estricto silencio.

De esta forma he edificado variables, construido categorías y las he nutrido a instancias del entrecruzamiento de los resultados que arrojan los testimonios, los documentos y el material bibliográfico. Para el análisis de los datos que surgen de los entrecruzamientos entre las fuentes por momentos recurro a los métodos de investigación histórica y comparativa, debido a las particularidades del tema elegido, ya que ayudan a afianzar la comprensión y análisis de las relaciones halladas.

\subsection{Tecnologías de ocultamiento o tecnologías de impunidad: esbozo de un marco conceptual}

La necesidad de esbozar unos conceptos en torno a los dispositivos montados por las Fuerzas Armadas para consagrar la impunidad de las torturas en Malvinas surgió al calor de los tiempos judiciales. En efecto, había que condensar, en un sintagma, toda la potencia que surgía de diversos testimonios. En este punto germinal resulta indispensable puntualizar que, como narro en la nota de campo 1, comencé a trabajar con la causa 1.777/07 en 2011. En dicho momento, no se había desclasificado el acervo documental que hoy da sustento a esta tesis, y que sirve para arribar a la abstracción que ha sido

\footnotetext{
${ }^{12}$ En muchas ocasiones dicho sentido se ha forjado al fragor de una historiografía bélica que se inscribe, a su vez, en un modo utilizado por la historia oficial y que resulta, en la mayoría de los casos, un recurso premoldeado en donde ubicar, a partir de la épica de la guerra, los hechos y sucesos relativos a nuestro pasado (Kohan, 2014).
} 
expuesta al momento de trazar la hipótesis, consistente en la edificación conceptual de las tecnologías de olvido o impunidad.

Así, la posibilidad de hablar de un "sistema", o de una planificación, inicialmente se basaba en las alocuciones y comentarios de exsoldados combatientes en Malvinas en general (los miembros CECIM La Plata -y las expresiones públicas del organismo-, Edgardo Esteban, entre otros), y las víctimas en particular. Quedaba claro cómo las Fuerzas Armadas habían instituido una lógica, aunque su edificación, su exteriorización eran aún una incógnita.

Con la desclasificación de los archivos (Decreto 200/2012 y Decreto 503/2015), comenzó a quedar al desnudo una genealogía de poder:

$$
\begin{aligned}
& \text { una genealogía de lo que Foucault denominó } \\
& \text { "gubernamentalidad", entendida como punto de fuga entre una } \\
& \text { teoría jurídico-institucional del poder y el modelo biopolítico } \\
& \text { constituido por ciertas tecnologías y dispositivos individualizantes } \\
& \text { y totalizantes (Raffin, 2018: 112) }
\end{aligned}
$$

Fue entonces que, una vez en contacto con los archivos, comenzamos a vislumbrar el modo preciso con que las Fuerzas Armadas habían actuado. Esa urdimbre comenzaba a cobrar forma, a delinear contornos. Ahora bien, todo ese cosmos de piezas documentales se resignificaba con los relatos, permitía comprender determinadas lógicas actitudinales de los exsoldados conscriptos combatientes en Malvinas. Sin embargo, faltaba el elemento aglutinante. Aquel capaz de condensar, en pocos vocablos una caracterización elocuente. La desclasificación de archivos venía después de algunos sinsabores judiciales, como respuesta del Poder Ejecutivo frente a los mismos, y como acervo documental, constituía el "eslabón perdido", lo que patentizaba el diseño de dispositivos político/burocráticos. Estábamos del lado de los vencidos, queríamos escribir su historia, dar la palabra a quienes [no habían podido] tomarla hasta el presente, a quienes fueron forzados al silencio por la historia (Foucault, 2014: 55).

El descubrimiento fue fascinante. Se había montado un dispositivo. No había sido sólo el temor que imponía el Estado criminal. Éste se había abocado al diseño de una técnica y unas lógicas. Ellas pueden ser rastreadas en la teoría. 
Mientras los juristas o los filósofos buscaban en el pacto un modelo primitivo para la construcción o la reconstrucción del cuerpo social, los militares, y con ellos los técnicos de la disciplina, elaboraban los procedimientos para la coerción individual y colectiva de los cuerpos. (Foucault, 2014b: 197)

Hay, en el desempeño de las Fuerzas Armadas, una lógica disciplinar, que en el caso de los exsoldados combatientes de Malvinas adquirió la morfología que puede advertirse de la inmersión en el campo de los documentos, y de la semiosis específica que emerge del entrecruzamiento con los testimonios. Así, en primer término, advertimos la práctica generalizada, con reiteración en sus modalidades de comisión, de la tortura:

\footnotetext{
El suplicio [...] no cubre cualquier castigo corporal: es una producción diferenciada de sufrimientos, un ritual organizado para la marcación de las víctimas y la manifestación de poder que castiga, y no la exasperación de una justicia que, olvidándose de sus principios, pierde toda moderación. En los "excesos" de los suplicios se manifiesta toda una economía del poder. ${ }^{13}$ (Foucault, 2014b: 44)
}

En línea con lo expuesto, es interesante pensar en los porqués de la escritura, de dejar plasmadas en documentos oficiales determinadas prácticas. Aquello, que podría causar asombro, es en parte un elemento central del modo en que las Fuerzas Armadas han montado, a lo largo del tiempo, los dispositivos de poder.

\footnotetext{
Para que la disciplina sea siempre ese control, esa captura permanente y global del cuerpo del individuo, creo que está necesariamente obligada a utilizar un instrumento que es la escritura. [...] podríamos decir que la disciplina, con su exigencia de completa visibilidad, su constitución de los moldes genéticos, esa
}

\footnotetext{
${ }^{13}$ Si bien Foucault (2014b: 44) se refiere al suplicio "penal", entiendo que el constructo teórico aplica a la perfección para las prácticas de torturas que infligieron los miembros de las Fuerzas Armadas a los exsoldados combatientes de Malvinas.
} 
suerte de continuum jerárquico que la caracteriza, apela por fuerza a la escritura. Ante todo, para velar por la anotación y el registro de todo lo que ocurre, de todo lo que hace el individuo, todo lo que dice; a continuación, para transmitir la información de abajo arriba a lo largo de la escala jerárquica, y por último, para poder mantener siempre accesible esa información y asegurar así el principio de omnivisibilidad que es, creo, la segunda gran característica de la disciplina.

El uso de la escritura me parece absolutamente esencial para que el poder disciplinario sea global y continuo (...) (Foucault, 2008:

69)

Emerge entonces, ese punto de fuga entre el poder gubernamental y la biopolítica (Raffin, 2018: 122), los diálogos y tensiones entre el poder político, estatal, y el sujeto, su singularidad.

\footnotetext{
Todo esto constituye al individuo disciplinario; todo esto, finalmente, ajusta entre sí la singularidad somática y un poder político. Y lo que podemos llamar individuo no es aquello a lo cual se aferra el poder político; lo que debemos llamar individuo es el efecto producido, el resultado de esa fijación, por las técnicas que les he indicado, del poder politico a la singularidad somática. (Foucault, 2008:78).
}

He llamado al dispositivo político/burocrático implementado para con los exsoldados combatientes de Malvinas, tecnologías de ocultamiento o impunidad. Al referirme a esos conceptos, estaré desnudando o reconstruyendo las diversas lógicas y dinámicas utilizadas por las Fuerzas Armadas, y su consecuente cristalización escrituraria plasmada en los documentos, por las que el poder político produjo a los sujetos de la guerra, alejándolos de la noción del padecientes, de la idea de víctima.

\section{Nota de campo 1: mi ingreso al CECIM La Plata}


Año 2011. Hacía 2 años me había recibido de abogado en la Universidad Nacional de La Plata (17 de diciembre de 2009). Entre 2008 y finales de 2010 participé activamente de la Asamblea Permanente por los Derechos Humanos La Plata. Allí se había conformado un grupo de jóvenes. Recuerdo a Joaquín Lanfranchi, Yamila Manes, Vanesa Manes, Santiago Giorello, Bruno Falco, Silvina Negrete, Estefanía Mancini, Laurentina Alonso y Alejandra San Mauro.

Todos/as veníamos de ámbitos diversos. Algunos/as estudiábamos derecho, otros/as comunicación social y sociología. Con algunos/as llevamos adelante, durante dos años, el programa Tengo Derechos, que se transmitía en vivo por Radio Universidad los sábados a la mañana.

Entre las múltiples actividades, participamos en la cobertura (y algunos aportes jurídicos) en el Juicio Unidad 9 La Plata. Forjamos una hermosa amistad. También atravesamos instancias de formación política. En uno de los encuentros conocía a Ernesto Alonso ("Beto"), papá de Laurentina, exsoldado combatiente de Malvinas, miembro del CECIM. Nos habló de Malvinas en clave nuestramericana, y de las violaciones a los derechos humanos que se habían dado durante la guerra. Fue un anticipo, una foto, un filamento...

Vuelvo así a agosto o septiembre de 2011. No recuerdo con precisión el mes. Recibo un llamado o un mensaje de Laurentina Alonso, y alguna comunicación de Silvina Negrete. Me hablaron con alboroto. El alboroto, ha sido una constante. Una hermosa constante. La causa por torturas a soldados en Malvinas pendía de un delgado hilo. Casación había había fallado que los delitos denunciados no eran crímenes de lesa humanidad y sobreseído a uno de los denunciados.

Había que escribir un recurso extraordinario federal. ¡Bueno! Pensé. ¡Manos a la obra! La inconsciencia que brinda la juventud. Había visto, leído, estudiado, y hasta dado exámenes relacionados con ese recurso, pero a ciencia cierta no sabía cómo era. Alguien, en ese caos, me acercó una acordada que, recuerdo (aunque no muy bien hoy), establecía cuántos renglones debe tener la presentación, los márgenes, y la extensión máxima. ¡Qué temor! Resumir, ser concretos. Expresar “agravios constitucionales”... ¡Uff! Nuevamente, la impertinencia.

El recurso fue declarado inadmisible por la Sala I del Tribunal Nacional de Casación Penal. Inadmisible. Algo habíamos leído, y algunos consejeros de alto vuelo nos arrimaron la frase: "ahora vayan en queja". Queja. Recuerdo mirar hacia arriba y bucear en alguno de los libros que había leído unos años antes, o en una frase suelta de 
algún profesor o profesora... "la queja queda expedita en aquellos casos en que..." ¡Siempre falta el remate!

Lo cierto es que lo hicimos. Una de las preguntas más maravillosas fue ¿Y ahora dónde presentamos esto? Teníamos el escrito, pero no sabíamos cuál era la ventanilla, ni si había que ensobrarlo, ni nada. Además, tuvimos que hacer un depósito de dinero. Creo que Luis Aparicio, en ese entonces mago y tesorero del CECIM, proporcionó los fondos (si no recuerdo mal cinco mil pesos). Alguien arrimó un timbrado del Banco Nación, que abrochamos al escrito.

Toda la secuencia, con la espada de los plazos procesales pendiendo de nuestra cabeza. A la presentación siguió una tranquilidad enorme. Lo habíamos logrado. Hay dinámicas que tienden a poner el foco en dimensiones prácticas. Nuestro gran desafío, ese 2011 fue poder hacer un escrito y presentarlo. Era difícil poder visualizar que, en aquel momento, intentábamos que los torturadores no quedaran impunes, que había más de un centenar de personas que habían denunciado, que habían roto ese mandato de silencio y que, consecuentemente, habían depositado en el CECIM la confianza de la representación a instancias de su querella. Lo que tampoco sabía, era que esa causa se transformaría en una de las obstinaciones de mi vida adulta y, sobre todo, profesional, y que el organismo iba a ser el gran responsable de decisiones personales trascendentales.

\section{Nota de campo 2: CECIM La Plata, un martes cualquiera}

Asistir un martes al CECIM La Plata es una experiencia edificante. Desde 1982, al término de la guerra, los martes constituyen el momento de encuentro. En su sede de 21 y 40 de la ciudad de La Plata (desde 1985), ese día, partir de las 18:30 se puede acudir. La reunión de Comisión Directiva del organismo está llamada a las 19, aunque nunca comienza antes de las 19:30, 19:45.

He podido acudir con regularidad desde 2011, año de mi incorporación como abogado. Hay, en esos encuentros, un componente catártico, de acompañamiento. Allí, los pesares, las experiencias traumáticas de la guerra se resignifican, se reconfiguran. Reina la alegría y el compañerismo. Incluso, se pueden escuchar bromas, o la apelación "vetuka", para llamarse entre sí, o para hablar en tercera persona ("al vetuka le gusta"). Durante el desarrollo de la reunión suele presentarse un clima un tanto más 
solemne. Hay un orden del día. Se repasan allí las actividades realizadas durante la semana (la semana del CECIM va de martes a martes) y las que vendrán.

También, se debaten lineamientos o posturas políticos o institucionales. Una de las cuestiones que más llamaron mi atención fue la definición de Beto al tiempo de haber ingresado al organismo. Él me manifestó que el CECIM era un organismo de derechos humanos. Comprender las lógicas de un ámbito creado en la guerra, como hecho germinal, como punto de partida, constituyó un desafío. Los miembros del CECIM no se encontraron, desde el vamos, a instancias de una identidad política preexistente. Por el contrario, forjaron dicha identidad a partir de la resignificación de la figura del exsoldado conscripto.

Cuando el debate se torna eterno, espeso, o en aquellos momentos en que, de vez en cuando emergen posturas encontradas, siempre aparece Chiquito. Chiquito es un compañero del CECIM y oficialmente el cocinero. A tal punto es central su llamado, su dimensión aglutinadora, que la cocina del organismo lleva su nombre. Él, con su porte imponente (debe medir cerca de 2 metros), realiza un gesto con la mano y da paso al "milagro de chiquito". El debate se apaga, sus participantes se levantan y lentamente circulan al comedor. Allí se come asado, pollo, guisos, o cualquier otra cosa. La comida es la excusa. El vino circula. Las charlas pasan a ser del orden de la anécdota cotidiana. A veces, asisten invitados o invitadas. A todos/as ellos/as se les rinde homenaje. Una suerte de ritual de agradecimiento. Y se los incluye. Desde "los muchachos" del banco donde cobran las pensiones, pasando por "los muchachos" de la ferretería del barrio, o diputados nacionales, alguna personalidad de la política o del arte. Dicha experiencia es, como he dicho, edificante. Ni hablar si uno de esos martes el "Ruso" toca su acordeón. Al salir, siempre recuerdo el final de "Lucas, sus amigos" de Julio Cortázar:

No es inútil agregar que Lucas regresa a su casa con la sensación de que arriba de los hombros tiene una especie de zapallo lleno de moscardones, Boeings 707 y varios solos superpuestos de Max Roach. Pero qué le importa la resaca si abajo hay algo calentito que deben ser las empanadas, y entre abajo y arriba hay otra cosa todavía más calentita, un corazón que repite qué jodidos, qué jodidos, qué grandes jodidos, qué irreemplazables jodidos, puta que los parió. 


\title{
2.- En contexto
}

\section{1.- Dictadura}

El 24 de marzo de 1976 se puso en marcha el autodenominado "Proceso de Reorganización Nacional"14 - nombre nada inocente ya que remitía a un proceso previo de la historia argentina que tuvo lugar entre 1862 y 1880, cuyas connotaciones aún eran mayoritariamente positivas para nuestra sociedad - y en los hechos implicó la instauración de la dictadura más sangrienta de nuestra historia nacional; la "más violenta y mortífera”, en palabras de Rouquié (2017: 156). El Decreto de fecha 24 de marzo de 1976 publicado el 31 de marzo de 1976, en su artículo $1^{\circ}$ expresaba:

\begin{abstract}
Artículo $1^{\circ}$-La Junta Militar, integrada por los comandantes generales del Ejército, la Armada y la Fuerza Aérea, órgano supremo de la Nación, velará por el normal funcionamiento de los demás poderes del Estado y por los objetivos básicos a alcanzar, ejercerá el Comando en Jefe de las Fuerzas Armadas y designará al ciudadano que, con el título de Presidente de la Nación Argentina, desempeñará el Poder Ejecutivo de la Nación. (D'Andrea Mohr, 1998)
\end{abstract}

De esta forma quedaba inaugurado un gobierno dictatorial que instituyó a lo largo del territorio nacional y a instancias de la Doctrina de la Seguridad Nacional, un Plan Sistemático de Exterminio ${ }^{15}$ que incluyó, entre diversas atrocidades la propagación de la

\footnotetext{
${ }^{14}$ Las Fuerzas Armadas irrumpieron en el poder el 24 de marzo de 1976, y perduraron en el mismo hasta el 10 de diciembre de 1983, fecha en la que asumió el Presidente electo Raúl Ricardo Alfonsín.

15 Probado en la Causa No 13/84. "El 9 de diciembre de 1985, la Cámara Federal dicta sentencia en el marco del Juicio a las Juntas Militares (Causa 13. Año 1985). La sentencia confirmaba la noción de un plan sistemático de exterminio, justificaba la fuerza probatoria de los testigos y descalificaba los argumentos de la defensa. Sin embargo, las condenas fueron menores que las pedidas por el fiscal en su alegato.

Los acusados fueron los integrantes de las tres primeras juntas militares: Jorge Rafael Videla (Comandante en Jefe del Ejército entre 1976 y 1978), Emilio Eduardo Massera (Comandante en Jefe de la Armada entre 1976 y 1978) y Orlando Ramón Agosti (Comandante en Jefe de la Fuerza Aérea, entre 1976 y 1978) que conformaron la primera junta militar (1976 - 1980); Roberto Eduardo Viola (Comandante en Jefe del Ejército, entre 1978 y 1979), Armando Lambruschini (Comandante en Jefe de la Armada, entre
} 
tortura, la desaparición de personas, los saqueos, la práctica de ejecuciones sumarias, la instalación de campos de concentración (centros clandestinos de detención y exterminio), y el robo sistemático de niños y niñas, entre otras.

\begin{abstract}
Con el advenimiento del gobierno militar se produjo en forma generalizada en el territorio de la Nación, un aumento significativo en el número de desapariciones de personas (...)

Las personas secuestradas eran llevadas de inmediato a lugares situados dentro de unidades militares o policiales o que dependian de ellas, que estaban distribuidos en el territorio del país, cuya existencia era ocultada al conocimiento público. (Cámara Nacional de Apelaciones en lo Criminal y Correccional Federal de la Capital Federal, 1985)
\end{abstract}

Además, se construyó desde lo discursivo un enemigo interno al acecho para poder lograr el apoyo indispensable de la ciudadanía civil. Fueron demonizados el Estado, a partir del lema "Achicar el Estado es Agrandar la Nación” empleado por Martínez de Hoz (Fair, 2014); las diferentes militancias; las mujeres en un doble juego de exaltación de su rol de "madres" y a la vez de responsabilización por criar "subversivos" ( "Señora... ¿Sabe dónde están sus hijos en este momento?”'16); se jugó con las construcciones del "buen vecino" y "mal vecino" fomentando un modelo de ciudadano potencialmente delator; y con varias otras representaciones que excederían ampliamente los marcos de este trabajo (Bravo, 2003). Pero este "enemigo interno" encarnó fundamentalmente en los jóvenes. Así, las juventudes que integraban la trama social del momento fueron las destinatarias del más brutal disciplinamiento del que se tenga memoria (Lvovich, 2009).

1978 y 1981), Omar Domingo Rubens Graffigna (Comandante en Jefe de la Fuerza Aérea, entre 1978 y 1979), que formaron parte de la segunda junta militar (1980-1981); y Leopoldo Fortunato Galtieri (Comandante en Jefe del Ejército, entre 1979 y 1982), Jorge Isaac Anaya (Comandante en Jefe de la Armada, entre 1981 y 1982), Basilio Lami Dozo (Comandante en Jefe de la Fuerza Aérea, entre 1979 y 1982), que integraron la tercera (1981-1982).

Los únicos que recibieron la pena de prisión perpetua fueron los integrantes de la primera Junta Militar, mientras que los de la tercera fueron absueltos." (Memoria Abierta)

16“"Sólo algo más. Durante la dictadura de Videla, a las diez de la noche, una voz, desde el televisor, preguntaba: “¿Usted sabe dónde está su hijo ahora?”. Era la voz del Orden. De la seguridad. Era la voz del terror. Porque muchos, demasiados, no sabían dónde estaba su hijo. Ni podían saberlo. No por "malos padres", sino porque el régimen de la seguridad y del orden se los había secuestrado." (Feinmnan, 2005) 
Estas metodologías estuvieron orientadas a la realización de una transformación estructural de la economía, la sociedad y el estado imprescindibles -a la luz de los hechos que se dieron previa y posteriormente en América Latina - para la instauración de un modelo económico que resultaba impensable ejecutar mediante procesos democráticos. La relación entre la instauración del terror y el proyecto económico la desarrollan numerosos autores como Feinmann (2006), aunque ya la advertía el periodista asesinado el 25 de marzo de 1977 Rodolfo Walsh en su "Carta a la Junta Militar" (1977). Sin embargo, esta relación nunca adquirió - a mi entender - la centralidad que merece.

En síntesis,

La dictadura militar, que interrumpió la democracia argentina el 24 de marzo de 1976 y mantuvo el poder hasta el 10 de diciembre de 1983, transformó la estructura económica y social del país y condicionó la vida política de los siguientes años. A partir del disciplinamiento de la sociedad en general y de los movimientos populares en particular -basado fundamentalmente en diversos modos de represión- el gobierno de facto se abocó a la tarea de reemplazar el modelo de sustitución de importaciones que prevalecía desde la década del 30 por una amplia apertura económica y el predominio de capitales extranjeros en la economía nacional.

Estas medidas de nivel político-económico fueron acompañadas en todo momento por inusitadas formas de violencia política, pero también por otras sofisticadas de persuasión, desplegadas para lograr el consenso necesario que permitiera llevar a cabo su plan de "reorganización”. En este marco, el discurso, entendido como espacio simbólico en el que se despliega la lucha por la construcción de la realidad, cumplió un papel fundamental al condicionar la visión del mundo y la acción de los sujetos individuales y colectivos.

En efecto, a partir de discursos y acciones, inseparables desde nuestro punto de vista a la hora de analizar los procesos sociales, la última dictadura militar construyó el marco adecuado para moldear la sociedad a fin de lograr sus objetivos. (Bravo, 2003: 108) 
La guerra de Malvinas constituyó un capítulo más de la dictadura cívico/militar. Como es desarrollado a lo largo de la presente investigación, los paralelismos, las continuidades, los artífices, las lógicas de formación y acción fueron las mismas. Comprender esta particularidad nos debe llevar a asumir que los exsoldados conscriptos combatientes en Malvinas han sido la última víctima colectiva del Terrorismo de Estado.

En dicho sentido, la dimensión reparatoria en lo que concierne al conflicto bélico, tanto en términos individuales (víctimas directas, familiares, entre otras), como colectivos, en concreto, el derecho que asiste al pueblo argentino de conocer qué sucedió durante la guerra, resulta ser una cuenta pendiente de la democracia argentina.

\section{2.- Doctrina de la Seguridad Nacional}

Durante la Segunda Guerra Mundial se llevó adelante la IIa reunión de Consulta de Cancilleres en La Habana ${ }^{17}$. En ella se instituyó el principio de que "un ataque contra una nación americana, por parte de una nación no americana, se consideraba una agresión contra todas las naciones del continente".

Una vez ingresado Estados Unidos en el desarrollo la Segunda Guerra Mundial, se reunió la IIIa Conferencia de Cancilleres en Río de Janeiro ${ }^{18}$ donde se resolvió convocar a expertos militares de la región para que se reunieran en Washington con la misión de trazar los lineamientos que organicen la defensa del continente. Dichos sucesos llevaron a que se constituya la Junta Interamericana de Defensa y que luego se firme el Tratado Interamericano de Asistencia Recíproca (TIAR) ${ }^{19}$.

Es importante remarcar que durante aquellos años se crearon dos organismos internacionales de suma importancia: la Organización de Naciones Unidas (octubre de 1945) y la Organización de Estados Americanos (abril 1948), cuya Carta establecía la creación de un Comité Consultivo de Defensa que nunca llegó a instituirse (artículo 66 de la Carta).

La Junta Interamericana en un comienzo comenzó a cumplir las funciones que le correspondían al Comité Consultivo previsto originalmente en la Carta de la OEA

\footnotetext{
${ }^{17}$ La Habana, Cuba, julio de 1940.

${ }^{18}$ Río de Janeiro, Brasil, enero de 1942.

${ }^{19}$ Río de Janeiro, Brasil, 2 de septiembre de 1947.
} 
(artículo 66), dado que los Cancilleres se reunieron y establecieron que, hasta tanto contara con organismos idóneos para abordar la materia, la Junta Interamericana de Defensa llevaría adelante el mentado papel, impartiendo recomendaciones en materia de defensa continental.

En 1951, el Congreso estadounidense dicta la ley $N^{\circ} 165$ de Seguridad Mutua. Esta ley permite que las Naciones Americanas intercambien entre sí material de guerra. Por supuesto que nosotros a los Estados Unidos no le vamos a prestar ningún material de guerra. Quien presta material de guerra es Estados Unidos a las naciones latinoamericanas. $Y$ el hecho de prestar material de guerra le otorga a Estados Unidos el derecho de establecer en el país recepcionante una misión militar con fines de asesoramiento. Con esto queda prácticamente estructurada la famosa doctrina de la Seguridad Nacional. Las Fuerzas Armadas de nuestros países deben estar preparadas fundamentalmente para luchar contra la subversión interna, eso en especial para el caso del Ejército. La Marina debe facilitar el tránsito por el Atlántico Sur, para que en ese enfrentamiento entre el Este y el Oeste, el Atlántico Sur no sea negado a la navegación de Occidente. Y la Fuerza Aérea debe colaborar con la Marina o con el Ejército de acuerdo con sus respectivas necesidades. Nuestros países no deben organizar tropas para combatir en el exterior. El peso de las operaciones en contra del enemigo principal, la Unión de Repúblicas Socialistas Soviéticas y los países del Pacto de Varsovia, será llevado por Estados Unidos y sus aliados de la OTAN. Nuestros países tienen que tener pequeños destacamentos de intervención, no sólo porque no confian en poder asignarnos la responsabilidad de un frente, sino, fundamentalmente, para que nuestras banderas figuren en intervencionismos, tipo el de Santo Domingo de 1965, para que los intereses norteamericanos sean defendidos por una aparente comunidad de naciones americanas. (D'Andrea Mohr, 1998)

Mediante la utilización de las llamadas "recomendaciones", la Junta delimitó la función de los ejércitos del continente americano y, más tarde, modeló al enemigo ideológico. Las Fuerzas Armadas, bajo este esquema, pasaron a tener una preparación militar pensada en la lucha contra el enemigo interno. 
En nuestro país ya tenía antecedentes: la amenaza comunista fue invocada en la proclama de 1943 (Leyes, 2017), como un peligro originado en la injusticia social.

Los gobiernos dictatoriales que ejercieron el poder desde el golpe en $1966^{20}$ enumeran como último punto de sus objetivos particulares la política de seguridad, definida como "la aptitud integral necesaria para asegurar la obtención de los objetivos en los otros ámbitos" (Acta de la Revolución Argentina, punto F del Documento de Objetivos). Dichos objetivos constituyen el acta de nacimiento en nuestro país de la "Doctrina de la Seguridad Nacional"; que reaparecerá en 1975 con la proclama de Capellini ${ }^{21}$, y cobrará desarrollo pleno en los documentos de la Dictadura cívico-militareclesiástica iniciada el 24 de marzo de 1976.

En efecto, el día del golpe, al enumerar sus objetivos, se enuncian como tercero, quinto y octavo (Junta Militar, 1980):

\footnotetext{
“(.... 3) Vigencia de la Seguridad Nacional, erradicando la subversión y las causas que favorecen su existencia.

5) Concreción de una situación socio-económica que asegure la capacidad de decisión nacional y la plena realización del hombre argentino, en donde el Estado mantenga el control sobre las áreas vitales que hacen a la seguridad y al desarrollo y brinde a la iniciativa y capitales privados, nacionales y extranjeros, las condiciones necesarias para una participación fluida en el proceso de explotación nacional de los recursos, neutralizando toda posibilidad de interferencia de aquellos en el ejercicio de los poderes públicos.

8) Conformación de un sistema educativo acorde con las necesidades del país, que sirva efectivamente a los objetivos de la Nación y consolide los valores y aspiraciones culturales del ser argentino. (...)’. (Junta Militar, 1980)
}

\footnotetext{
${ }^{20}$ Comandados sucesivamente por los Generales Juan Carlos Onganía, Marcelo Levingston y Alejandro Lanusse, de la autodenominada «Revolución Argentina».

${ }^{21}$ Entre el 18 y el 23 de diciembre de 1975 el país fue sacudido por la violencia: el 18, un intento de golpe de Estado encarado por un brigadier de la Fuerza Aérea intentó derrocar al gobierno de la entonces Presidenta María Estela Martínez de Perón. (Bevilaqua, 2010)
} 
¿Por qué vincular la Doctrina de la Seguridad Nacional a la guerra de Malvinas? La respuesta surge diáfana pese a que se ha investigado poco al respecto. Las Fuerzas Armadas no se encontraban formadas para la "defensa", sino para la represión de lo que se había caracterizado como el "enemigo" interno. En dicho sentido, las conclusiones del Informe Rattenbach, desclasificado en el año 2012, permiten constatar las afirmaciones aquí vertidas al caracterizar, como se verá, a la guerra como una "aventura militar".

\footnotetext{
En el plano táctico y logístico llegaron a haber falencias tales que hubo casos de "serios problemas de desnutrición en los soldados y fallas en el debido aprovisionamiento de armamento y municiones. Si bien en el marco de la guerra hubo proezas en los escalones inferiores, no se podía ganar de manera alguna si los altos mandos carecian de virtudes. (Rattenbach, 2014)
}

Esas Fuerzas Armadas, formadas para la tortura, las desapariciones, el exterminio, fueron las mismas que condujeron las hostilidades. Sin un desarrollo táctico ni estratégico acorde a la empresa propuesta (conforme surge del Informe Rattenbach). Sin planificación. Sin un despliegue operacional a la altura de lo que es dable en considerar en un jefe militar superior como lo era por entonces el teniente general Leopoldo Fortunato Galtieri.

\title{
2.3.- La guerra de Malvinas
}

\author{
"La guerra es la justicia hecha a sí mismo, y como nadie \\ se encuentra injusto hacia los otros, la guerra es \\ la justicia de la barbarie, porque es la \\ injusticia misma."
} (Alberdi, 2007)

En relación con lo que se plantea en el presente capítulo, resulta pertinente un artículo que escribí para el libro "Malvinas en clave de Derechos Humanos. Experiencias, 
desafíos y tensiones" (2018), titulado Malvinas a la luz del derecho internacional, que cito a continuación:

La guerra de Malvinas hace referencia al conflicto armado que la República Argentina mantuvo con el Reino Unido durante el año 1982. Visto desde la perspectiva nacional, el informe Rattenbach calificó al hecho bélico como una "aventura militar", dado el nivel de improvisación con que se condujeron desde la estrategia y la táctica las acciones por parte del Estado argentino.

\section{El 2 de abril de 1982, a las 6.30, soldados argentinos desembarcaron en las Islas Malvinas, logrando el control del territorio. Al día siguiente habrían de controlar también las Georgias del Sur. (Pejlatowicz, 2013: 308)}

Un punto saliente que permite dar cuenta de la falta de planificación por parte de los mandos de las Fuerzas Armadas argentinas es la conformación de las unidades militares, integradas por soldados conscriptos clases 1962 y 1963, estos últimos en fase de instrucción en virtud de la vigencia del Servicio Militar Obligatorio.

La guerra llegó a su fin el 14 de junio de 1982 con la rendición en Puerto Argentino rubricada por Mario Benjamín Menéndez, y en sus 74 días de duración se cobró la vida, durante el conflicto bélico de 639 argentinos (Centro de Ex Soldados Combatientes en Malvinas de Corrientes, n.d.) de los que 122 fueron enterrados como N.N. en Cementerio de Darwin $^{22}$, y de los que han sido identificados 115 a la fecha ${ }^{23}$.

Hasta aquí una breve caracterización del hecho bélico, del que existe nutrida bibliografía ${ }^{24}$. Sin embargo, en los últimos años, fruto de la consolidación democrática

\footnotetext{
${ }^{22}$ De las 237 tumbas emplazadas en el Cementerio de Darwin, 122 contienen la leyenda "soldado argentino sólo conocido por Dios". Ello motivó la presentación de una acción de amparo tramitada por ante el Juzgado Nacional en lo Criminal y Correccional $\mathrm{N}^{\circ} 10$, en la que el Centro de Ex Combatientes Islas Malvinas La Plata, en representación de los familiares de los soldados enterrados como N.N. solicitó al Juez que ordene al Poder Ejecutivo que arbitre todos los medios necesarios para llevar adelante la identificación. En virtud de ello, el en agosto de 2017 culminaron las tareas de identificación llevadas adelante por la Cruz Roja Internacional. Para noviembre de 2019 se han reconocido 115 soldados.

${ }^{23}$ Marzo de 2020.

${ }^{24}$ Entre la bibliografía que habla del tema, se puede mencionar: Malvinas La Trama Secreta (Cardoso, O. R., Kirschbaum, R., \& Van Der Kooy, E, 1992); Malvinas. Un anacronismo colonial (Romero, 2014); Narrar y escuchar Malvinas. 30 años de posguerra (Giordano, Lino y otros, 2012); Malvinas en clave de Derechos Humanos: experiencias, desafíos y tensiones (Giordano, Guerrero Iraola, Alonso, 2018); entre otra.
} 
que vive la República Argentina, se han dado a conocer distintas causas que apuntan a los sucesos sufridos por soldados argentinos durante la guerra.

Como he afirmado a lo largo de la presente investigación, la guerra de Malvinas constituyó un capítulo más de la dictadura cívico/militar. En este sentido, resultan esclarecedoras las apreciaciones de María Maneiro (2005). Si bien la autora no desarrolla en su Tesis ninguna referencia al conflicto bélico con Gran Bretaña, si aborda la ingeniería desplegada por la Dictadura para instaurar el terror, y varias de sus consideraciones resultan de especial interés para este trabajo.

La primera es el reconocimiento de las implicancias de la producción y realización de un genocidio, que, afirma, requieren de la puesta en marcha de diversos mecanismos que fueron ejecutados en diferentes partes del territorio nacional, y en diferentes coyunturas (Maneiro, 2005).

En segundo término, reconoce y puntualiza esas diferencias de metodología, pero advierte que esas modalidades, aparentemente "desorganizadas" no pueden considerarse excepciones o excesos, sino que esa especificidad pudo mantenerse por resultar "funcional" al objetivo. En este sentido, la autora nombra a esas aparentes "desviaciones" como "relleno estratégico", que según las sugerencias de Michel Foucault son aquellas acciones cuyos efectos no han sido premeditados como conformadores de un dispositivo específico, pero resultan absolutamente funcionales a los objetivos estratégicos del mismo (Maneiro, 2005).

Por último, un tercer punto relevante es el de los tormentos aplicados. La autora aborda sus denominadores comunes y sus modalidades diferentes. En efecto, habla de tormentos practicados a las víctimas para la obtención de información, y de los practicados sólo por placer o por alguna otra motivación como disciplinamiento, homofobia, intolerancia religiosa, misoginia, etc. La autora colige que más allá de los motivos, todas estas modalidades no implicaron ruptura con la lógica genocida, sino que aportaron una nueva complejidad que, buscada o no, colaboró en la diseminación del amedrentamiento de la población en su conjunto (Maneiro, 2005). A estas formas de aplicación de la tortura las denomina "fría y aséptica" por un lado; "inquisitorial" por otro. Sostiene que en la primera, la tortura constituye un modo de construcción de información operativamente valiosa; mientras que la segunda se presenta como ritual purificador o venganza concreta (Maneiro, 2005). 
Las consideraciones expuestas considero revisten especial trascendencia para el análisis que me propongo realizar, ya que ayudan a la comprensión de que las vulneraciones de derechos humanos perpetradas contra los conscriptos durante la guerra de Malvinas no consistieron en hechos aislados llevados a cabo por algunos integrantes de las Fuerzas Armadas que "se excedieron", sino que forman parte de una trama mayor sobre la que intento reflexionar. En este punto, resulta imprescindible aclarar que las motivaciones que guiaron la imposición generalizada de tortura no constituyen en sí el objeto de la tesis. Sin embargo, se visualiza con claridad dentro de la caracterización propuesta por la autora que las practicadas a los exsoldados combatientes en Malvinas fueron del tipo inquisitorial (Maneiro, 2005), llevadas a cabo como ritual purificador después de una "desobediencia" para procurarse alimentos, por pertenecer a un grupo étnico religioso o de género específico, u otra venganza concreta a las que alude Manerio (2005). Los motivos de la instauración de la tortura como práctica sistemática de la Dictadura y las especificidades que revistió en cada caso podrán, eventualmente, constituir un campo interesante para el desarrollo de futuras investigaciones.

Así, se han recopilado a lo largo y ancho de nuestro país alrededor de 120 denuncias de homicidios y torturas y otros tratos crueles, inhumanos y/o degradantes perpetrados por miembros de las Fuerzas Armadas argentinas en perjuicio de los soldados conscriptos $^{25}$.

Además, se retomó una investigación por presuntas violaciones a las disposiciones de los Convenios de Ginebra cometidas durante (y después) de la batalla de Monte Longdon $^{26}$, y de las que habrían resultado víctimas soldados argentinos ${ }^{27}$."

De esta forma, la sucinta descripción del período 1976/1983 aquí realizada permite tender algunas líneas histórico/argumentativas que habiliten a dimensionar las lógicas y dispositivos empleados por las Fuerzas Armadas e integrar consecuentemente la guerra de Malvinas a la urdimbre de la ominosa historia que signó el mencionado lapso temporal.

\footnotetext{
${ }^{25} \mathrm{El}$ expediente $1.777 / 07$ se abordará en detalle en la presente investigación.

${ }^{26}$ La batalla de Monte Longdon tuvo lugar entre la noche del día 11 y la madrugada del día 12 de junio de 1982.

${ }^{27}$ Lo expuesto ha dado lugar a la interposición de una denuncia por parte del Centro de Ex Combatientes Islas Malvinas La Plata, ante el Juzgado Federal de Río Grande, Tierra del Fuego, Argentina por la presunta comisión de crímenes de guerra. Expediente 63000453/1998.
} 
La decisión de 'Ocupar las Islas Malvinas' fue tomada porque ya existía, desde diciembre de 1981, la idea de que para llegar a negociaciones exitosas con Gran Bretaña iba a ser necesario hacer uso del poder militar. La decisión se adoptó con rapidez puesto que ya estaba planeada la ocupación, lo que permitía cumplir la etapa inicial. Pero nunca se planificó cómo defender las islas una vez ocupadas.

En definitiva, la decisión, que se mantenía latente, estuvo influida por aspectos políticos particulares, tal, por ejemplo, la conveniencia de producir una circunstancia significativa que revitalizara el Proceso de Reorganización Nacional...

Cuando el 2 de abril de 1982 la población se sorprendió por la ocupación de las Islas Malvinas... los triunviros creyeron haber logrado, por fin, sortear el descrédito, el desprecio y el desastre social y económico del plan que apoyó el golpe de 1976. (D'Andrea Mohr, 1998)

La misión de anudar las experiencias implica indagar en la doctrina que nutrió a las dictaduras del Cono Sur, evaluar las órdenes de las líneas de mando, las prácticas de sus ejecutores, las víctimas, los dispositivos de ocultamiento de las acciones y sucesos, los vectores sociales, económicos y políticos que atravesaron en modo transversal el período 1976/1983.

\section{4.- Archivos}

\subsection{1.- El proceso de desclasificación}

La posibilidad de acceder al acervo documental ha resultado, sin lugar a duda, el paso más significativo en lo que concierne a la posibilidad de reconstruir, a instancias de documentos oficiales, la postura asumida por la Dictadura en relación con el conflicto bélico.

Puntualmente, en lo que atañe al objeto de la presente investigación, es importante subrayar dos hitos gubernamentales, acaecidos en el año 2012 y 2015 respectivamente. Se trata, en concreto, del Decreto 200/2015: 
Artículo $1^{\circ}$ - "Relévase de la clasificación de seguridad establecida, conforme con las disposiciones de la Ley $N^{o} 25.520$ y su Decreto Reglamentario $N^{\circ}$ 950/02, al Informe Final elaborado por la "COMISION DE ANALISIS Y EVALUACION DE LAS RESPONSABILIDADES POLITICAS Y ESTRATEGICO MILITARES EN EL CONFLICTO DEL ATLANTICO SUR" (Informe RATTENBACH), sus antecedentes documentales, anexos generados por las Fuerzas Armadas y toda otra fuente utilizada para la elaboración de dicho Informe."

En conjunto con el Decreto 503/2015:

\author{
Artículo $1^{\circ}$-Relévase de la clasificación de seguridad, establecida \\ conforme a las disposiciones de la Ley $N^{\circ} 25.520$ y su modificatoria, \\ a toda aquella documentación, de carácter no público, vinculada al \\ desarrollo del Conflicto Bélico del Atlántico Sur obrante en los \\ Archivos de las FUERZAS ARMADAS
}

Estos Decretos, que son abordados en apartados posteriores, han sido centrales en la misión de recuperar un rasgo del Terrorismo de Estado: la estatalidad doble, consistente en la maquinaria burocrática/administrativa que pretende dar visos de legalidad al obrar institucional, y que funciona como vehículo de la comisión de graves violaciones a los derechos humanos en la "trastienda", es decir, vedados a los ojos de la ciudadanía. Los documentos en cuestión, permiten apreciar ese doble juego, por un lado la comisión de torturas y otros tratos crueles, inhumanos y/o degradantes, y por el otro, la maquinaria estatal tendiente a sembrar un manto de impunidad.

\title{
2.4.2.- Comisión de Evaluación de las Operaciones en las Islas Malvinas: Informe
} Calvi

La Comisión de Evaluación de las Operaciones en las Islas Malvinas, presidida por el general de división Edgardo Néstor Calvi se constituyó mediante expediente confidencial el 5 de junio de 1982. 
La misión de la Comisión Calvi fue determinar si la conducta del personal que el Comandante en Jefe del Ejército (CJE) pusiera a su disposición resultaba encuadrable en infracción penal o disciplinaria, susceptible de ser considerada por un Tribunal de Honor u objeto de un reconocimiento honorifico. Las acciones que se desprenden de estas investigaciones - instruir actuaciones, otorgar distinciones, entre otras - no fueron realizadas por la Comisión sino que se efectuaron a través de otros canales de la institución. Finalmente, esta comisión elaboró un informe final sobre el conflicto al que se agregaron planillas sobre el personal a ser sometido a investigación, personal a ser considerado por la Comisión de Otorgamiento de Distinciones, personal a ser considerado por la Junta de Calificaciones y personal con mención especial en la unidad. A su vez, es de resaltar que la Comisión Calvi escribió un anexo especial con observaciones sobre el resultado de las operaciones en Malvinas, en lo que sería un análisis estratégico de la guerra. En éste concluye que es necesario que el CJE disponga las evaluaciones que corresponden a tal efecto ya que no es atribución de la comisión realizar tal tarea, la que realizará la CAERCAS. (Ministerio de Defensa de la República Argentina, n.d.)

La potencia del Informe Calvi surge de su lectura en conjunto con el Informe Rattenbach. Se trata de documentación oficial forjada "en caliente" que sirve para recrear el contexto, las lógicas, las disposiciones burocráticas y estatales.

La diversidad y cantidad de archivos va urdiendo la trama que, en forma paulatina, permite no sólo comprobar la hipótesis inicial, sino también darle sustento.

\subsection{3.- Informe de la Comisión de Análisis y Evaluación de las Responsabilidades del Conflicto del Atlántico Sur (CAERCAS): Informe Rattenbach}

Un elemento de incalculable valor para ponderar la hipótesis que se aborda en la presente investigación es el Informe de la Comisión de Análisis y Evaluación de las Responsabilidades del Conflicto del Atlántico Sur (CAERCAS), conocido como Informe Rattenbach, desclasificado mediante Decreto del Poder Ejecutivo Nacional N²00/2012. 
El Informe Rattenbach fue elaborado por la Comisión de Análisis y Evaluación de las responsabilidades políticas y estratégico militares en el conflicto del Atlántico Sur. Una vez terminado el Conflicto Bélico del Atlántico Sur, la Junta Militar argentina que ejercía el gobierno de facto de la Nación creó, a través de la resolución $N^{\circ} 15$ del año 1982, una comisión integrada por seis Oficiales del Grado de Generales, dos por cada Fuerza Armada, la cual se encontraba presidida por el Teniente General (R) D. Benjamín Rattenbach. Su finalidad sería elaborar un informe sobre las responsabilidades emergentes respecto de la conducción política y estratégico militar del conflicto. Una vez presentado el documento se dispuso, mediante Decreto $N^{o} 2971$ de fecha 11 de noviembre de 1983, que las actuaciones así como el informe final tengan el carácter de "secreto político" y "secreto militar".

(Seoane, 2015)

El voluminoso Informe se encuentra integrado por 17 tomos. Su estructura se encuentra caracterizada en el Informe "El regreso de los soldados de las islas Malvinas: la trama del ocultamiento" de las autoras Gamarnik y Guembe (2018).

El "informe final” producido por la Comisión está compuesto por 17 tomos: "Cuerpo del Informe Final”, encuadernado en un volumen único de 291 folios numerados.

"Anexo al Informe Final", encuadernados en 10 tomos numerados de I al X. Es la documentación utilizada para la confección el Informe.

“Declaraciones”, cinco tomos numerados de I al V

“Actas”, encuadernado en un volumen único.

El Cuerpo del Informe Final está dividió en 5 partes que se dividen en capitulos y a su vez en títulos y subtítulos. La primera parte corresponde a la Introducción (Parte I) que incluye la Resolución de la Junta Militar y Acta de constitución de la Comisión de Análisis y un "Glosario" de abreviaturas militares utilizadas a lo largo del Informe. El contenido de las Partes II a $V$ se describe en detalle en un índice en la foja 20. Corresponden 
a: II. Antecedentes del conflicto, III. Evaluación y análisis crítico,

$I V$. Determinación de las responsabilidades, V. Experiencias y enseñanzas. Las Partes II a V tienen numerado sus párrafos correlativamente del 1 al 890.

Finalmente se adjunta el acta de constancia de finalización de la Comisión, donde se detallan los destinatarios de los diez ejemplares firmados del informe: la Junta Militar, los Comandantes en Jefe de las Fuerzas Armadas y un ejemplar para cada uno de los seis miembros de la comisión. (Gamarnik y Guembe, 2018: 26/27)

Así, la fusión de las políticas de Defensa Exterior y Seguridad Interior instauradas por la Doctrina de la Seguridad Nacional se tradujo no sólo en todo lo que concierne al Plan Sistemático de Exterminio desplegado en territorio continental argentino, sino también en el modo en que se desplegaron las acciones bélicas protagonizadas por la República Argentina durante la Guerra de Malvinas en 1982.

El Informe Rattenbach da por tierra con la mitología que se pretendió edificar de Malvinas como "gesta heroica", al desnudar la impericia, los graves errores cometidos en el plano táctico y la falta de planificación estratégica. A su vez, el componente aludido se acentúa si se atiende al carácter de la instrucción de Oficiales y Suboficiales, entrenados para perseguir y exterminar a sus connacionales.

605. Al iniciar las hostilidades enfrentando una hipótesis de guerra inédita, el Ejército Argentino no se hallaba debidamente adiestrado ni capacitado para sostener un conflicto bélico de la magnitud y características del que se llevó a cabo y contra un enemigo con experiencia y un poder militar superior. La mayor parte de la clase 1962 habia sido dada de baja, mientras la clase 1963 apenas habia completado su incorporación, pero no su instrucción básica. Ello fue motivo de que numerosos soldados hayan sido enviados al Teatro de Operaciones Malvinas sin haber completado la instrucción elemental de tiro y combate. (Comisión de Análisis y Evaluación de las Responsabilidades Políticas y Estratégico Militares en el Conflicto del Atlántico Sur, 1983) 
A la luz de la semiosis jurídico/histórica que se construye en la presente investigación, el Informe Rattenbach reviste especial trascendencia, dado que, como ya he puntualizado desnuda el hecho de la falta de planificación táctica/estratégica. El mismo hace sentido con los postulados ya analizados relativos a la Doctrina de Seguridad Nacional, al introducir un elemento analítico que permite advertir cómo las Fuerzas Armadas argentinas habían sido formadas en forma preeminente para la represión interna.

\section{Nota de campo 3: Hugo Robert rememora la situación del cañón 105. Una mirada a propósito del Informe Rattenbach}

En Internet circula un video, en el que Hugo Robert, miembro del CECIM, cuenta, en ocasión de un viaje a Malvinas, una situación que le tocó vivir, junto a sus compañeros de la Compañía C durante la guerra. He podido ver ese material en varias oportunidades. No obstante, nunca antes había hablado con él al respecto.

Martes 7 de abril de 2020. El 2 de abril aún sobrevuela. Este año no se pudo llevar a cabo el acto en Plaza Malvinas, debido al aislamiento social, preventivo y obligatorio decretado debido a la pandemia de COVID-19.

Son las 16:21 horas y decido mandarle un mensaje de Whatsapp. Le pido que, si puede, si no le molesta y, sobre todo, si tiene ganas, me mande un mensaje de audio contando con detalles la situación del cañón 105.

Un rato más tarde, a las 19:04, recibo el material. Me parece una pieza elocuente. Por cómo lo cuenta. Por cómo cambia su voz. Por su enojo patente al rememorar. Comparto una transcripción:

"Estuve poco tiempo en el Regimiento 7, porque durante el servicio militar obligatorio había trabajado en una oficina. Había hecho la instrucción, sabía manejar el FAL, pero no tenía mayor conocimiento.

En el fondo de la cuadra, de la Compañía C, la cuadra es el lugar donde duermen los soldados, había un cañón que hasta ese entonces pensé que era un adorno. Pensé ¿Con qué van a adornar una cuadra? Y con un cañón. Parecía un cañón viejo, de la segunda guerra.

Cuando lo reencuentro en Malvinas a ese Cañón, no lo podía creer, que lo que pensaba que era un adorno, disparaba. Era el cañón 105, un cañón con dos ruedas que en asfalto andaba bárbaro, el problema es que nos mandan con cinco soldados y un cabo 
primero, Pérez, nos mandan a buscarlo a Moody Brook, que era el lugar donde había estado asentado el cuartel de los Royal Marines. A unos cuantos kilómetros de la Compañía C. Y nos dan una serie de aparejos y sogas para llevarlo hasta la Compañía C, entre los 5 soldados y el cabo que, por supuesto, no tocaba el cañón. La fuerza la hacíamos los soldados. Pero la verdad es que el cabo $1^{\circ}$ se da cuenta de que era imposible mover ese trasto, porque se hacía ingobernable por el suelo de Malvinas, un suelo muy difícil, con turba. Te enterrás, te empantanás fácil. Solamente transitarlo a pie es complicado, imagináte con un cañón 105 . Entonces el cabo $1^{\circ}$ dice, en un alarde de ingenio, que esperemos hasta que oscurezca, oscurecía muy pronto en Malvinas, así no nos veían, entonces lo subimos en las lomadas y lo largamos. Donde cae, lo vamos a buscar.

Así lo llevamos. Así llevamos el cañón 105. A los tumbos, a los golpes. Por su puesto que ese cañón, el día que tuvo que actuar, que fue la mañana del 12 de junio de 1982, increíblemente logró disparar una munición. Increíblemente, digo, por los golpes que se había dado el cañón. Era difícil pensar que eso podía llegar a funcionar. Disparó una sola munición y no anduvo más. Una munición, estaban los helicópteros ingleses, ya se veían en cercanía de las posiciones de la compañía $\mathrm{C}$, y mientras nosotros veíamos esa mañana los helicópteros, el cañón logró disparar una munición y cayó para siempre. Era bastante lógico. Por eso cuando algunos dicen "las balas silbaban para todos", me gustaría saber por qué los cráneos que idearon la logística del Ejército argentino, por lo menos los del Regimiento 7, no pagaron sus culpas. Las culpas por ejemplo de ese cañón. Como tampoco nunca entendía por qué los encargados de la compañía C del Regimiento 7, dejaron un soldado como WA con un arma que no disparaba. Me cansé de decirlo. Todavía estoy esperando que algún fiscal me indague así ratifico lo que sigo sosteniendo. Son tantas las barbaridades que cometieron, que la frase que utilizan aún hoy los Oficiales y Suboficiales del Ejército para esconderse detrás del heroísmo de los soldados que pusieron el pecho en Malvinas... las balas no silbaron para todos igual, para nada. Los soldados, primero, los soldados no torturaron en Malvinas. Los Oficiales y Suboficiales sí. Y no me hago cargo de los buenos comportamientos, porque es el Ejército quien se encargó de esconderlos, los malos comportamientos. Entonces que sea el Ejército quien ponga la cara ante la sociedad y diga quién se comportó dignamente, y quién fue indigno del uniforme que llevaban. Las balas, no silbaron para todos igual. Los que se rajaron, muchos, fueron Suboficiales y Oficiales. No los soldados. Entonces que no vengan con que ahora no, ahora somos todos héroes, la guerra no distinguía grados. ¡Pindonga no distinguía grados! La realidad es que los que pusieron el pecho, por lo menos en la 
Compañía C fueron los soldados. Y eso, repito, lo saben todos los que estuvimos en la Compañía C. Lo sabe García, lo sabe Ibáñez, lo sabe Camaño, se rajaron bien temprano, dejaron a sus soldados en el frente y los reencontramos en puerto argentino. Entonces, eso de que las balas silbaron para todos igual, que se la vayan a cantar a otro. A mí, y a los compañeros de la Compañía C del Regimiento 7, no nos pueden engañar. Que hubo comportamientos dignos, sí, claro que los hubo. Pero que se rajaron muchos del combate, fueron ellos. Los que torturaron soldados, fueron ellos. No hay soldados torturadores."

\section{Nota de campo 4: Germán Bonanni y la radio sin pilas, releyendo el Informe Rattenbach}

Con Germán, miembro del CECIM, hemos conversado en varias oportunidades. Sus historias suelen ser profundas. Detalladas. Por eso, mientras pensaba en cómo poder contrastar algunos aspectos más formales, fríos y/o despersonalizados de la investigación, consideré muy importante pedirle que aporte una de sus anécdotas. Martes 7 de abril de 2020. Sigo dando vueltas con la tesis. Estamos aislados por la pandemia de COVID-19. Le mandé un mensaje vía Whatsapp a Germán y le pido que, si así lo desea, que grabe en un audio alguna de las tantas anécdotas que ha vivido durante la guerra. Me contesta que sí. Que le de unas horas, que está por tomar unos mates. Así, casi sobre el final del día, recibo el audio.

8:30 del miércoles 8 de abril, transcribo la anécdota de la radio sin pilas:

“Tenemos que ir un poquito más para atrás y decir que mi grupo, que era el tercer grupo de la tercera sección, de la Compañía C del Regimiento 7 estaba formado por integrantes de la sección destinos. Estos eran los oficinistas, como era mi caso, y todos los que tenían un oficio dentro del Regimiento, plomeros, gasistas, pintores, oficinistas como era el mío, esto te marca que la instrucción militar era muy inferior a la que tenían los soldados de las Compañías de infantería. Bueno, con eso, cuando se hizo el segundo llamado para formar otra vez el Regimiento 7 que se había ido de baja, con los que no vinieron, fueron sacando de esta sección destino. Así, en esa condición de poca formación militar, fuimos a Malvinas. Eso como para tener una idea.

Llega un momento que nos viene a buscar el Jefe de Compañía, nos dice a ver, a los ocho soldados de la tercera sección, con sus bolsos, a Puerto Argentino. Bueno, así salimos. No sabíamos bien qué era lo que teníamos que hacer. Llegamos a Puerto 
Argentino, nos atiende el Jefe de Regimiento que nunca lo habíamos visto porque jamás nadie ha ido a donde estábamos nosotros en la avanzada y nos dice muy serio, soldados, ustedes van a formar parte de la historia de esta República. Y bueno, uno empieza a pensar en lo que se refiere, en formar parte de la historia y ser parte de la historia. Bueno, viene el capellán, nos da una misa, el asistente del teniente coronel que era jefe nos convida chocolate, algo realmente inédito y nos suben a un helicóptero. Lógicamente ninguno sabía dónde íbamos a ir. Éramos ocho soldados, un cabo, un soldado que se había enganchado en la carrera militar y el subteniente más joven que había dentro de todo el Regimiento 7. Bueno así fuimos un buen rato de vuelo hasta que nos dejan muy cerca de la costa y nos dicen, bueno, su trabajo acá va a ser avisar si ven el desembarco británico, que suponemos que va a ser por acá, el desembarco británico, avisar por radio y replegarse. Cuando empezamos a acomodar las cosas nos dieron provisiones para dos días, y empezamos a acomodar las cosas y nos dimos cuenta de que nos habían dado una radio sin pila. La radio no andaba, lo que era el fin de nuestra aventura ahí, que después nos enteramos que era la Bahía San Carlos, no tenía ningún sentido porque nadie había controlado que las pilas de la radio estaban descargadas. Así transcurrió el día, nos hicieron hacer unas guardias y nos hicieron bajar a la costa. La niebla era tan profunda, tan profusa que dos de los compañeros se perdieron, y uno lo tuvimos perdido casi un día y medio hasta que lo pudimos encontrar. En una situación que ninguno sabía bien qué es lo que tenía que hacer. Pasaron los dos días y se acabaron las raciones. Llegó el tercer día y no teníamos para comer y no sabíamos, como no teníamos radio, no sabíamos si se habían olvidado de nosotros, qué era lo que había pasado y, de repente, al cuarto día, vemos llegar el helicóptero y dijimos bueno, zafamos. Ahí nos tiran un cordero, como para que comamos eso, quiero creer, y se vuelve a ir. Pero no nos dio ni tiempo para decirles que la radio no andaba. Y bueno, cuando empezamos a ver qué era lo que podíamos hacer con ese cordero, de qué forma lo podíamos comer, vino otro helicóptero que ahí sí paró y nos llevó de vuelta a Puerto Argentino. Uno ahora cuando piensa, piensa en las vicisitudes que ha pasado en Malvinas y todas las historias que son fáciles de narrar, pero difíciles de entender. Mandarnos a hacer un trabajo en el cual la logística era cero y la parte de materiales menos diez. Hoy lo cuento como una anécdota, pero después de haber vivido eso, soy un afortunado en poder estar contándola."

\subsection{4.- CEM}


La "Comisión Especial Malvinas" (CEM) comenzó a funcionar a partir del año 1987. Su objetivo era producir un documento de carácter histórico respecto del Conflicto Bélico del Atlántico Sur.

En el orden del día del Estado Mayor General del Ejército 69/87 establece que la Comisión deberá oficiar de "base a las futuras investigaciones históricas y difundiera las acciones heroicas del personal de la Fuerza durante la guerra". Para ello, la CEM requirió la documentación relacionada a Malvinas, motivo por el que contiene documentación del Informe Rattenbach, así como también del Informe Calvi.

Luego de la desclasificación de los archivos relativos al conflicto bélico del Atlántico Sur, mediante Decretos 200/2012 y 503/2015, se pudo acceder al fondo documental CEM, que en gran parte da sustento a la presente investigación.

\section{5.- Torturas en Malvinas}

"Brusco es el viento

que empuja a un soldado

herido en el monte"

Martín Raninqueo, Haikus de guerra

\subsection{1.- Orígenes: la denuncia que dio inicio a la causa $1.777 / 07$}

La causa se inició con la denuncia de $\mathrm{BA}^{28}$ ante la Secretaría de Derechos Humanos de la Provincia de Buenos Aires, que fue remitida por dicho organismo a la Fiscalía de Política Criminal de la Procuración General de la Nación.

En la presentación, el denunciante señaló que durante el desarrollo de la guerra de Malvinas sufrió, al igual que otros soldados, torturas y otros tratos humillantes y degradantes por parte de agentes del Estado pertenecientes a las Fuerzas Armadas.

BA se desempeñó en el grupo de artillería de fuerza aérea (GADA 601), Batería "A", tercera sección. En su denuncia, relata que, en una oportunidad, desesperado debido

\footnotetext{
${ }^{28}$ En adelante se utilizarán siglas para referirse indistintamente a víctimas y/o denunciantes, de acuerdo con lo dispuesto en la Ley 25.326 de Protección de datos personales.
} 
a que llevaba más de dos días sin comer, se alejó para buscar alimento y al regresar fue descubierto por el Subteniente Alemansor, quien decidió castigarlo por la desobediencia, ordenando al cabo Pedro Valentín Pierre que lo estaqueara. De esta forma, lo tendieron en el suelo boca arriba, a la intemperie, atado de pies y manos, y colocaron un poncho encima que lo cubría. BA permaneció 8 horas estaqueado (desde las 16:00 hasta las 24:00 aproximadamente) $\mathrm{y}$, encontrándose en dicha situación, escuchaba el impacto de diversos proyectiles en zonas cercanas. A su vez, relata que a pocos metros de donde estaba siendo torturado, había tanques de nafta.

El hecho que desencadenó la denuncia fue el haberse encontrado con la persona que lo estaqueó durante el desarrollo de las Olimpíadas Anuales para Veteranos de Guerra celebradas en la ciudad de Tandil en el año 2001, quien al verlo dijo a quienes lo acompañaban "miren quien entra $[\mathrm{BA}]$, pensar que yo a este negro lo estaqué en Malvinas pero como lo quiero" (denuncia de BA). Resulta importante remarcar cómo la ausencia de juzgamiento habilita una dimensión profundamente revictimizante, al propiciar este tipo de situaciones.

Finalmente, luego de un derrotero procesal, la causa quedó radicada bajo el número de expediente 1.777/07, caratulada "Pierre, Pedro Valentín s/ Delito de acción Pública" ante el Juzgado Federal de Primera Instancia de Río Grande, Tierra del Fuego, Antártida e Islas del Atlántico Sur ${ }^{29}$.

\subsection{2.- Las denuncias de Corrientes: el importante rol de "Iluminados por el fuego" y las industrias culturales}

Tiempo después, con la investigación en trámite por ante el Juzgado Federal de Río Grande, se presentó Pablo Andrés Vassel, en su carácter de Subsecretario de Derechos Humanos de la provincia de Corrientes, quien acompañó distintos testimonios colectados durante la realización de un evento cultural vinculado al 25 aniversario del 2 de abril de 1982, en la que, luego de la proyección de la película "Iluminados por el Fuego"30, los

\footnotetext{
${ }^{29}$ Causa 1.777/07, "Pierre Pedro Valentín y otro s/ Delitos de acción pública, iniciada en fecha 5 de enero de 2007, por Juzgado Federal de Río Grande, Tierra del Fuego, Antártida e Islas del Atlántico Sur.

${ }^{30}$ Iluminados por el fuego es una película argentina dirigida por Tristán Bauer en el año 2005. La película, una ficción inspirada en el libro homónimo escrito por Edgardo Esteban, narra las experiencias de Esteban Leguizamón, un excombatiente de la guerra de las Malvinas. (http://es.wikipedia.org/wiki/Iluminados_por_el_fuego)
} 
excombatientes que participaron de la actividad relataron haber sido víctimas de una serie de actos que fueron caracterizados como delitos de lesa humanidad ${ }^{31}$.

A partir de dichas denuncias, el 12 de abril de 2007 el Fiscal Federal de Río Grande, Tierra del Fuego, Antártida e Islas del Atlántico Sur formuló el correspondiente requerimiento de instrucción, en la que solicitó la investigación de veintitrés hechos.

Es importante en este punto, y dado que el objeto de la investigación se centra en la tecnología estatal (tecnologías de olvido o impunidad) diseñada para imponer el silencio, la importancia de un producto cultural, en concreto la película de Tristán Bauer basada en el libro de Edgardo Esteban (1993) que, en la identificación y el consecuente proceso catártico, habilitó la emergencia de relatos que hasta ese entonces habían estado mantenidos en secreto durante un cuarto de siglo.

\section{2-5-3 Las denuncias de Chaco: la federalización de la causa y su trámite}

Con posterioridad, diversos legisladores de la Provincia de Chaco, integrantes de la Comisión Permanente de Derechos Humanos, se presentaron en la causa, y acompañaron nuevos testimonios de excombatientes que fueron objeto de torturas durante el conflicto bélico.

Con el avance de la investigación surgieron nuevas víctimas, y se amplió la plataforma fáctica de la causa. De este modo, a abril de 2020 hay denunciados 95 miembros de las Fuerzas Armadas por 105 casos de tortura.

Entre los testimonios obrantes en un expediente que reúne más de 25 cuerpos, puede hallarse:

\footnotetext{
$Y$ vos contaste que pasabas mal porque tenías problemas con un sargento. ¿Qué pasaba con ese sargento? Lo que pasaba con ese sargento es que yo andaba bien con el subteniente Menéndez, y resulta que porque me tenía bronca, porque creía que yo era el alcahuete de él, entonces por eso la bronca que me tenía ese sargento... ¿Qué te hacía López? Me trataba mal, me agarraba y sacaba la pistola y me encajaba dos culatazos acá y dos culatazos acá y después yo cuando me levantaba, me encajaba una trompada así por debajo en la boca del estómago. Yo me caía y me levantaba
}

\footnotetext{
${ }^{31}$ Los testimonios recogidos por el Dr. Pablo Andrés Vassel dieron, asimismo, lugar a la publicación “Corrientes en Malvinas". El libro fue prologado por Estela de Carlotto.
} 
otra vez, de la patada me levantaba, "se tiene que levantar, hijo de una gran puta, usted tiene que hacer guardia sí o sí, levántese”. ¿Por qué vos te negabas a hacer guardia? Yo me negaba porque no podía estar parado. ¿Por qué no podías estar parado? Porque me faltaba alimento.

¿Qué hizo Taranto? Él le dio la orden al sargento, el sargento le comentó, entonces él le dice dale castigo, dale 24 horas de guardia sin darle de comer, sin darle desayuno, nada, 24 horas tiene que estar parado, tengo que estar ahí parado al lado de mi carpa.

Al cabo BB le estaquearon. ¿Quién le estaqueó? El subteniente Taranto. ¿Y por qué lo estaquearon? Por matar ovejas; él mataba ovejas para ayudarle a los soldados y resulta que le pillaron, entonces le estaquearon a él. Que según ellos eso no se podía hacer entonces lo estaquearon al soldado BB ¿Vos viste eso? Si, yo lo vi, si estaba a un costado de mi carpa. ¿Cómo lo estaquearon? Él estaba atado de las manos y los pies. Las manos y los pies estirados así. ¿Vestido? Sí, le puso la carpa encima para que no le caiga la lluvia, tenía que estar ahí, sí o sí, cinco días tenía que estar ahí. Entonces a BB, lo tuvieron cinco días... a BB lo tuvieron cinco días y cinco noches tirado en el piso. Yo me iba y le hablaba y le daba de comer al cabo BB. ¿Qué le dabas de comer vos? La comida que nosotros comíamos, sopa... pero vos me dijiste que no tenías casi comida.

Vos comentaste que te tenían en el agua. ¿Qué fue eso? Porque yo no podia hacer guardia, supuestamente yo no estaba en la guardia. Entonces preguntaban dónde está BC, yo estaba en la carpa entonces me agarraban y me metían en el depósito de agua y tenía hielo y me metían la cabeza ahí, y me tenían un ratito y me decian "vas a hacer guardia o no vas a hacer guardia", "sí, les decía y me apretaban así la cabeza otra vez.

¿No podías respirar en ese momento? No podía respirar. Eso me hacía el subteniente Taranto. Encima me sacó la pistola, yo no sé si él me habló en inglés cuando él me habla me sale toda espuma por la boca, cuando él me habla me dice: "tiene que hacer guardia hijo de una gran puta, BC, tiene que hacer guardia”. (Testimonio BC)

Este tipo de relatos, que dan cuenta de la inhumanidad de los tratos dispensados a los exsoldados conscriptos, son los que componen el expediente y los que permiten afirmar que durante la guerra de Malvinas se cometieron graves violaciones a los derechos humanos. 


\subsection{4.- El momento de mayor riesgo de la causa}

Uno de los miembros de las Fuerzas Armadas denunciado, se presentó ante el Juzgado Federal de Primera Instancia de Río Grande y solicitó la clausura del proceso alegando que la acción penal se había extinguido por prescripción. La Jueza de Instrucción y la Cámara Federal de Apelaciones de Comodoro Rivadavia, rechazaron oportunamente dicho planteo en el entendimiento de que los delitos que son objeto del proceso constituyen crímenes contra la humanidad según el derecho internacional aplicable y, por lo tanto, no están sometidos al régimen de prescripción de la acción penal que prevé el Código Penal para los delitos comunes.

“V.- Determinado entonces que los hechos objeto de la presente causa, constituirían prima facie "delitos de lesa humanidad", resultan de aplicación las normas de la Comunidad Internacional, por sobre las del derecho interno, por lo que el resolutorio impugnado habrá de ser confirmado [Al que refiere la nota al pie precedente].

En efecto, dicho tipo de crímenes goza de un estatuto jurídico particular del que se derivan consecuencias concretas en el juzgamiento de las personas sospechadas de su comisión. Así, como una concreta derivación del compromiso de las Naciones que integran la comunidad internacional, los mismos no están sujetos a plazo alguno de prescripción; carácter éste que la convención sobre la imprescriptibilidad de los Crímenes de Guerra y de Lesa Humanidad afirmó al señalar “...cualquiera sea la fecha en que se hayan cometido...”. Asi lo ha resuelto la Corte [Suprema de Justicia de la Nación] en el caso "Arancibia Clavel” al señalar que la disposición del art. 62 inc. 2 C.P. resulta desplazada por el Derecho Internacional consuetudinario y la Convención sobre la Imprescriptibilidad de los Crímenes de Guerra y de los Crímenes de Lesa Humanidad.

Por ende, la calificación de estos sucesos como crímenes de Lesa Humanidad y su consecuente imprescriptibilidad luce correcta, debiendo continuarse con la investigación de la presente causa”.

(Cámara de Apelaciones de Comodoro Rivadavia, 2009) 
Sin embargo, la Sala Primera de la Cámara Nacional de Casación Penal revocó la decisión de la Cámara de Apelaciones, pues encontró errónea la interpretación que ésta realizó de la categoría jurídica de crimen contra la humanidad. De acuerdo con su interpretación, esa categoría exigiría una conexión entre uno o más atentados individuales, por un lado, y una política estatal de ataque generalizado o sistemático a un sector de la población civil que no estaría dada en el caso de los crímenes que fueron objeto de proceso (Cámara Nacional de Casación Penal - Sala I, 2009).

Así, se reenvió la causa a la Cámara Federal de Apelaciones de Comodoro Rivadavia para que dictara una nueva sentencia acorde con la interpretación postulada en la sentencia casada. De esta forma, la Cámara de Apelaciones aplicó la interpretación al caso y declaró extinta por prescripción la acción penal surgida de los delitos investigados y sobreseyó al quien había interpuesto el planteo de prescripción.

Frente a ello, el Centro de Ex Combatientes Islas Malvinas (CECIM) interpuso recurso de casación contra la sentencia que dictó el sobreseimiento. La Cámara de Casación lo rechazó sobre la base del argumento de que el recurso no planteaba nuevas razones capaces de refutar las consideraciones.

El CECIM impugnó ese rechazo mediante un recurso extraordinario federal que la Cámara, a su vez, desestimó por tardío, aduciendo que la cuestión impugnada había quedado firme al no haberse impugnado la primera sentencia de casación en la que fijó la interpretación de la categoría de los crímenes contra la humanidad y se dispuso el reenvío para su aplicación a los hechos del caso. Esa desestimación motivó la queja que tanto el CECIM como el Fiscal de Casación, Dr. Javier de Luca interpusieron ante la Corte Suprema de Justicia de la Nación.

Ya en trámite el recurso ante la Corte Suprema de Justicia de La Nación, el entonces Procurador General de la Nación, Dr. Luis Santiago González Warcalde, se presentó ante la Corte Suprema de Justicia de la Nación ${ }^{32}$ y reclamó que se revocara la decisión que declaraba prescriptos los hechos y disponía el sobreseimiento del imputado.

Para fundamentar su reclamo, no sólo señaló que se encuentra fuera de discusión que las severas violaciones a los derechos humanos denunciadas encuadran bajo el término de tortura, sino que, al igual que el CECIM y los jueces de primera y segunda instancia, consideró que las mismas constituyeron crímenes de lesa humanidad, y por tanto no podían esgrimirse institutos de derecho interno como la prescripción. En

\footnotetext{
${ }^{32}$ Luego de que se le corriera vista.
} 
consecuencia, sostuvo que debían investigarse los hechos denunciados, pues de lo contrario se incurriría en el incumplimiento del deber de esclarecimiento de graves violaciones a los derechos humanos derivado de la obligación de respeto y garantía de derechos del artículo 1.1. de la Convención Americana de Derechos Humanos. Afirmó:

La percibida necesidad de "revitalización" ante la ciudadanía políticamente subyugada derivaba -según el informe- de la 'crisis socio-económica reinante', producto de las políticas desplegadas por el gobierno, las que daban lugar a nuevos 'movimientos políticos y sindicales internos que alteraban la paz' (cf. Informe Final, págs. 238 y sig., núm. marg. 784).

Entre las políticas que, a juicio de la junta militar, requerían ser compensadas de alguna forma mediante la producción de una 'circunstancia significativa' figuraba centralmente 'el problema de los derechos humanos' (cf. Informe Final, pág. 239, núm. marg. 785), eufemismo con el que el informe alude a la persecución política, secuestro, tortura y exterminio de millares de personas que, en la discusión traida ante V.E., se ha individualizado como el ataque a la población civil relevante para la evaluación de los hechos imputados en este proceso como crimenes contra la humanidad.

La 'circunstancia significativa' elegida fue la de explotar el antiguo reclamo de soberanía sobre las Islas Malvinas, que contaba con un amplio apoyo popular (cf., por ejemplo, Informe final, págs. 36, núm. marg. 153; 68 y sig., núm. marg. 290 y sig.; 175, núm. marg. 577). Así, la junta improvisó la ocupación militar de las islas, sin un plan de combate, sin capacidad para enfrentar a un enemigo militarmente más poderoso, movilizando a miles de soldados conscriptos sin instrucción militar y exponiéndolos a un clima hostil $y$ al fuego enemigo sin equipamiento apropiado y sin un apoyo logístico siquiera mínimamente adecuado (cf. Informe Final, especialmente capítulos VI, VII Y VIll).”

La improvisación logística de la que da cuenta el Informe Rattenbach (cf. especialmente, págs. 219 a 223) juega un papel central en los hechos que forman el objeto de este proceso. Las deficiencias logísticas produjeron padecimientos severos entre los soldados, quienes, reclutados forzosamente y prácticamente sin instrucción militar alguna, no siempre los aceptaron calladamente. Esas reacciones determinaron, a su vez, los tormentos aquí 
denunciados, dirigidos a disciplinar brutalmente a una tropa desprotegida.

Los tormentos imputados en este proceso fueron, así, precisamente una manifestación de varias de las muchas fallas de la 'aventura militar' en la que la junta que ocupaba de facto el gobierno embarcó a la nación mediante 'una serie de medidas irreflexivas y precipitadas' (cf. Informe Final, pág. 67, núm. marg. 282.c), movidas en parte por el objetivo político de obtener un apoyo social que contrarrestara la catástrofe de la que era responsable. Y como manifestaciones de las severas responsabilidades en las que incurrían por esa aventura militar los miembros del gobierno dictatorial (cf. Informe Final, capitulos X a XIII), las torturas estaban cubiertas por la misma garantía de impunidad que un régimen de esa naturaleza se brinda a sí mismo (González Warcalde, 2012)

\section{Y concluyó que:}

"El relato que antecede, basado como está en la información disponible en el informe oficial ordenado por el propio gobierno de facto -y declarado secreto por decisión del mismo gobierno de facto, pero hecho público sólo treinta años después, por disposición de los decretos $n^{o} 200 / 2012$ y $431 / 2012$ del Poder Ejecutivo Nacional-, muestra que la relación que la parte acusadora postula entre los delitos imputados en este procedimiento penal y el ataque contra una población civil identificado es, al menos, verosímil.

Esa verosimilitud, entiendo, obliga a revocar la sentencia de sobreseimiento impugnada. Pues, en efecto, a mi juicio -y como lo he expuesto en la sección IV de este dictamen-, el tipo de relación postulada es suficiente para dar por satisfecho el requisito legal de un nexo entre ataque a la población civil y violación particular de derechos exigido por el derecho internacional de los crímenes contra la humanidad. Y, por otra parte-como lo he defendido en la sección $V$-, la verosimilitud del planteo de que existe la conexión legalmente requerida entre una severa violación de derechos humanos y un ataque sistemático o generalizado contra una población civil es suficiente para impedir la clausura de la investigación penal de un probable crimen contra la humanidad." (González Warcalde, 2012) 
Frente a dichos recursos -a los que se les sumaron los escritos producidos por los amicus curiae Delegación de Asociaciones Israelitas Argentinas (DAIA), H.I.J.O.S. y la Comisión Provincial por la Memoria de la Provincia de Buenos Aires (CPM) ${ }^{33}$, que en el mismo sentido solicitaron la reapertura de la causa-, y luego de transcurridos tres años, la Corte Suprema de Justicia, en tres líneas y apelando a formalismos rituales que no eran de aplicación al caso, confirmó la resolución impugnada.

Dicha resolución abría una herida profunda en los denunciantes, quienes veían cómo el Estado argentino les daba la espalda. En este punto resulta crucial traer a colación las palabras de Ramos Padilla:

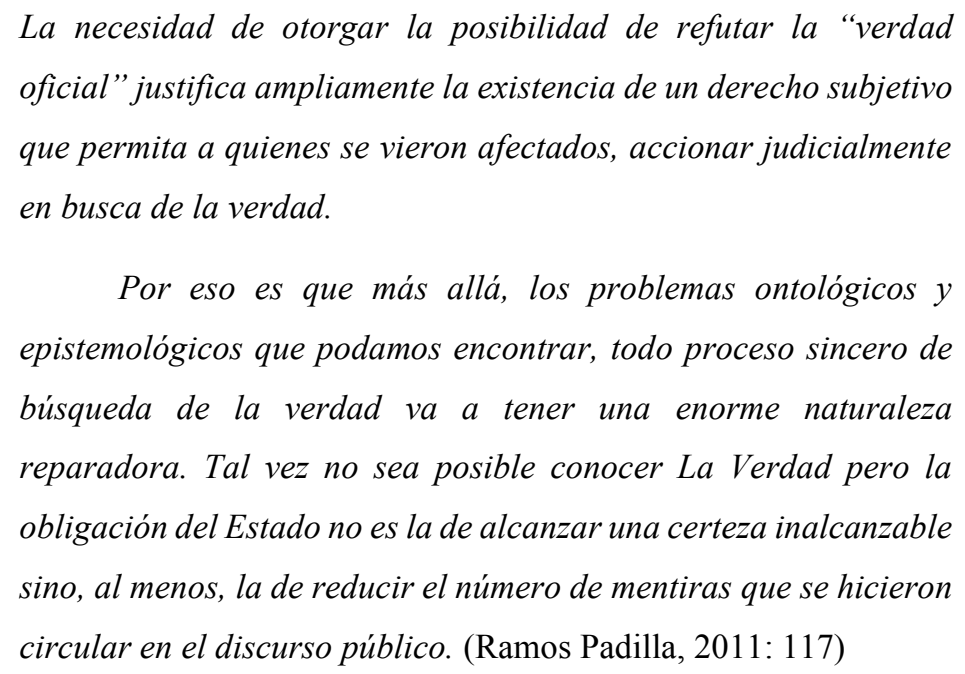

Resulta innegable la dimensión reparatoria que detenta la búsqueda de la Verdad, y su instrumentación a instancias de los procedimientos llevados a cabo por el Poder Judicial. En dicho sentido, si bien la causa continúa merced al esfuerzo de las querellas, es importante apreciar lo dificultoso que resulta deconstruir el relato oficial forjado, como se verá a lo largo de la presente investigación, durante el imperio del terrorismo de Estado.

\section{Nota de campo 5: Audiencia en Ushuaia con el Juez Federico Calvete}

\footnotetext{
${ }^{33}$ Hoy querellante en la causa $1.777 / 07$.
} 
4 de octubre de 2017. Juzgado Federal de Ushuaia, Tierra del Fuego, Antártida e Islas del Atlántico Sur. En ese entonces, el Juez Federal a cargo del Juzgado, Federico Calvete, subrogaba el Juzgado Federal de Río Grande. Con Ernesto (Beto), ya habíamos estado con él en alguna oportunidad previa, en una audiencia acalorada que se dio en su despacho. Una oficina amplia, de dos ambientes conectados. De un lado, el escritorio, y una biblioteca. Del otro, un living, compuesto de varios sillones de un cuerpo. Si no recuerdo mal, verdes. En medio de los sillones una mesa ratona. Esa parte de la oficina tiene ventanas amplias, que dan al Beagle, y por las que se filtra el sol, calienta la estancia. Siempre se ha dado la particularidad de que, las audiencias con Calvete, que deben haber sido 4 o cinco, se dieron con sol pleno.

Volvemos al 4 de octubre de 2017. Viajamos con una comitiva de la Comisión Provincial por la Memoria (CPM). Por el CECIM asistimos Mario Volpe, entonces Presidente. Ernesto Alonso y yo. Por la CPM Roberto Cipriano García, Sandra Raggio, Nora Cortiñas y Adolfo Pérez Esquivel.

Mario, Ernesto, Sandra, Roberto y yo viajamos el 3 a Río Grande, Tierra del Fuego, Antártida e Islas del Atlántico Sur. Allí la CPM se presentó como querellante. Luego nos trasladamos, ese mismo día, a Ushuaia. Adolfo y Nora nos esperaban allí. El 4, a las 10:00, nos esperaba Calvete.

La reunión se llevó adelante en un salón de usos múltiples. La escena, desde su configuración, fue extraña. Había una mesa, como si fuera un tablón. De un lado, Calvete, el resto de las y los participantes, ocupando los tres lados de la mesa restantes. Calvete estaba de espaldas a un ventanal que daba al Beagle. Si no recuerdo mal, de la reunión participaron el Rector de la Universidad Nacional de Tierra del Fuego, Daniel Guzmán, exsoldado y periodista. Había otras personas, pero sus caras hoy se tornan difusas.

Calvete intentó tomar la iniciativa. Creo, interpretándolo a la distancia, que aquella primera audiencia que habíamos sostenido con Beto le había dado la pauta de que debía pasar a la ofensiva. Habían pasado varios meses desde aquel primer encuentro. No recuerdo cuánto específicamente, pero sí puedo aseverar que casi un año. El Juez atacó. Fue primero contra la querella del CECIM. Expresó que a los requerimientos de indagatoria que habíamos presentado les faltaba precisión. Y luego adujo cuestiones propias de la organización interna del Juzgado. Falta de personal, entre otras.

Mi temperatura corporal comenzó a elevarse. Calvete se aferraba a los apoyabrazos de la silla. Ello, entiendo, parecía darle firmeza para hablar ante todos/as, quienes teníamos nuestros ojos clavados en él. Interrumpí sus excusas. Expresé que él era 
funcionario público y que, el Código Procesal Penal de la Nación, que aún (pese al proceso de cambio que estamos experimentando) es de corte inquisitivo, ponía en su cabeza el desarrollo de la investigación (a esa fecha, ni la Jueza Herraez, ni Calvete habían delegado la misma en el Fiscal de Río Grande -a la fecha tampoco ha sucedido-), por lo que era él quien debía efectivizar, con la prueba obrante en el expediente, los llamados a indagatoria. También, afirmé que los testimonios de las víctimas, y la documentación desclasificada (para 2017 conocíamos gran parte de su contenido), eran prueba suficiente como para sustentar una instancia tan germinal como es, sin dudas, la declaración del denunciado (indagatoria). Le recriminé que su obrar implicaba revictimización y vulneración a los derechos humanos, y que el Estado debía darle respuesta a las víctimas.

Hablé de los documentos desclasificados, allí comenzó a tomar forma la idea de la planificación de la impunidad a partir de la imposición de silencio. Lo acusé de ser un eslabón más de ese montaje.

Luego, tomaron la palabra, no recuerdo el orden, Sandra Raggio y Roberto Cipriano que, tras presentarse y aclarar que la Comisión Provincial por la Memoria iba a intervenir con carácter de querellante, hablaron de lo importante de dotar a la investigación de celeridad. De las obligaciones estatales en relación a las respuestas a las víctimas.

A su turno, hablaron Ernesto (Beto), quien siempre pone sobre la mesa la necesidad de llevar respuestas al colectivo al que, como exsoldado combatiente de Malvinas, miembro del CECIM, y querellante, representa. Sustentó mis dichos y expresó que el CECIM saldría a dar batalla en los medios de comunicación, denunciando la inacción judicial.

En sintonía con Ernesto, con Sandra y con Roberto, habló Adolfo Pérez Esquivel. Le expresó a Calvete la importancia de su rol, y el compromiso para con las víctimas. Para Calvete debe haber sido muy fuerte que el Premio Nobel de la Paz, estuviera allí, escrutando su obrar, dándole su parecer respecto a los estándares internacionales que el Magistrado debió cumplir.

En la misma línea intervino Nora Cortiñas. Les habló del sufrimiento de las víctimas, de la necesidad de alcanzar una respuesta por parte del Estado, de la importancia de la Verdad y la Justicia para la democracia argentina.

Fue una audiencia intensa. Quedó marcada a fuego en mi subjetividad. Fue intenso compartirla con otros querellantes, y que por la Comisión Provincial por la Memoria participaran Adolfo y Nora. Idolatrados por mí, ahora compartíamos una instancia formal 
de trabajo signada por la militancia. Por el deseo intenso de alcanzar la justicia, de arribar a un juicio oral y público.

En ese orden, valga la siguiente digresión. La posibilidad de conocer personas increíbles, de nutrirme de ellas, ha sido una constante en mi tránsito por el CECIM. Baltazar Garzón, Taty Almeida, Estela de Carlotto, Nora Cortiñas, Adolfo Pérez Esquivel, Alejo Ramos Padilla, Orlando Pascua, Pablo Vassel. Ello sin contar mis compañeros, todos y cada uno de los integrantes del organismo. Considero que en esos pliegues se ha ido forjando una identidad profesional y, ahora, académica. Durante aquella audiencia en Ushuaia con Federico Calvete sentí, por un instante, que la correlación de fuerzas comenzaba a emparejarse.

\subsection{5.- Los hechos que se investigan}

La mayoría de los denunciantes sitúan el foco en la carencia de alimentos, pese a que existe un consenso generalizado que da cuenta de la existencia de provisiones que eran repartidas entre la superioridad. En este sentido, BD, quien pertenecía al Regimiento 5 de Infantería de Paso de Los Libres, Compañía “A”, a cargo del Tte. Estela, refirió que era asistente del jefe de la tercera sección Tte. Jorge Candia y ello le permitió comer bien cuando estaba de servicio. Manifestó que en la carpa comando había un cajón donde se guardaban provisiones que nunca repartían y que cuando se produjo la rendición fue escondida y tirada. Agregó que los soldados se procuraban la comida de cualquier modo, por ejemplo, a instancias de carnear una oveja, y que realizaban estas acciones aún a costa de saber que si eran descubiertos serían sancionados con estaqueamiento o enterramiento ${ }^{34}$.

Con respecto a los estaqueamientos y según surge de las denuncias obrantes en el expediente, la mayoría se habrían producido luego de que los soldados fueran descubiertos tratando de procurarse por sus medios la alimentación que no les era suministrada por los altos mandos. A su vez, a los soldados se les propinaron otras torturas tales como enterramientos ordenados por sus superiores, simulacros de fusilamiento, inmersiones en agua congelada ${ }^{35} \mathrm{y}$ demás aberraciones.

\footnotetext{
${ }^{34}$ Los enterramientos consistían en que el sancionado debía cavarse el pozo en el que se lo enterraba hasta el cuello y en el que debía permanecer durante horas.

${ }^{35}$ En este punto es pertinente el informe climatológico elaborado por John Cappelen y Jens Jensen Juncher (período 1931 - 1960). «Teknisk rapport - Jordens Klima - Guide til vejr og klima i 156 lande» (en danés).
} 
Sólo a modo de ejemplo, podemos citar el testimonio de AB, de la compañía "B" del Regimiento de Infantería Mecanizada $N^{\circ} 3$ de La Tablada, a los efectos de generar una real dimensión de las acciones criminales que se investigan en la causa 1.777/07. El denunciante relató que al momento de llegar a Malvinas no tenían la ropa ni el equipamiento adecuado, y que llegó a pesar $58 \mathrm{Kg}$. mientras su peso promedio es de 90 $\mathrm{Kg}$ :

"Un día decido ir a buscar comida y me escapo al pueblo, consigo la comida entre la basura, cambié el reloj que tenía y me dieron panceta, latas... cuando llego a mi posición ya me estaban esperando el Subtte. Flores, Fiocchi, Sto. González y Cancino, estaban haciendo la revista de equipo a toda la compañia, por cualquier cosa le decía al resto que por culpa de [AB] los castigaba por ejemplo, los metieron al lago, hoy no comen, hoy vuelven a hacer guardia doble, y muchas cosas más. Ahi mismo Flores, Fiocchi y Cancino me meten la yerba que traía toda en la boca, para ahogarme y Pucca nunca intervino para evitar la situación. Flores, Fiocchi y Cancino me llevan a el Bunker de Flores donde veo que tiene toda la comida, me hacen tirar la comida, la mezcla con mierda humana y me la hicieron comer, comenzando a pegarme, me deforman la cara de los golpes, me golpean con el fusil FAL una en la costilla, me quiebra tres costillas y la clavícula, casi pierdo el ojo derecho, me hacen caminar por la zona minada ida y vuelta dos veces, ese fue Cancino, me mandan a pegar por la tropa. Flores me manda a estaquear, a desvestir, me sacan todo el equipo, el armamento, junto a mi estaban BE y BF estaqueados, me pone una granada en la boca, me manda a poner un lazo de carpa alrededor del cuello para que tuviera la cabeza agachada y una estaca en los testículos atada con el lazo para que no me moviera, toda la tropa presenció esto, ya que mandó a la tropa a que me mearan $^{36}, B F, I A, C A, B E, B A, D A, D B, K A, G A, D C$, fueron testigos. A todo esto mandan a un soldado a que cada dos o tres minutos me tirara agua helada, no sé cuánto tiempo pasó, perdi el conocimiento. El soldado DB de la Sección Apoyo Mortero que

DMI.DK. p. 87. (http://web.archive.org/web/20130427173827/http://www.dmi.dk/dmi/tr01-17.pdf). El mismo, permite dar cuenta de las temperaturas promedio para la época del año en que se llevó adelante el hecho bélico, a saber, entre el 2 de abril y el 14 de junio de 1982.

${ }^{36}$ Con esa expresión refiere a cómo los superiores ordenaron al resto que lo orinaran. 
estaba a cargo del Tte. Frecha le avisa lo que me estaban haciendo y él va a la sección y me saca, en una palabra me salva la vida y me lleva a su sección y me da el arma de él, yo quedé ahí me dieron morfina, en el momento de entrar a combate me manda a mi sección $y$ de ahi a cubrir la retaguardia del Regimiento 7 que los estaban acribillando y yo con la pistola, avanzaban los ingleses, estaban atacando en Monte London. El Subtte Flores que era quien nos tenía que guiar al puesto de Combate abandona la posición y nos guía otra persona, y empiezan a bombardear con morteros y el caos cada cual a correr por su vida. Viene la rendición nos desarman, tiramos las correderas al agua para que los ingleses no pudieran tomarlas nos trasladan al aeropuerto y de ahí a Puerto Argentino y nos guardan en unos galpones llenos de comida, de ahi me trasladan en el buque inglés Camberra como prisionero junto con los suboficiales. Cuando subo creen que yo habia caído en combate herido y me mandan al hospital del barco y me hacen las primeras curaciones, me dan unas medias térmicas, llegamos y me mandan como urgencia al Hospital Aeronaval de Chubut, de ahi me trasladan como urgente en avión de Aerolíneas Argentinas a Campo de Mayo donde me hacen las curaciones placas me enyesan tenia pie de trinchera, congelamiento de miembros, me revisan el ojo, fracturas de clavícula y costillas, todo consecuencia de las torturas. Ahi estuve dos meses, en ese tiempo vienen a visitarnos algunos Suboficiales, el Sgto. González y me dicen que yo me callara la boca si no iba a tener problemas e iba a desaparecer, me dijo que yo declarara que mis secuelas fueron por una bomba de mortero, ellos querían que yo firmara algo pero no lo hice, mi madre estuvo los dos meses conmigo y GA estaba en frente de mi cama, le digo a mi madre que me quiero ir, que me amenazaron, no me querían dejar ir, pero al final me dieron el alta. Agarré mis cosas y me fui, me fui ese mismo día para Uruguay, y por veinte años no pisé Argentina..."

Por su parte, víctimas como BA señalaron, al momento de denunciar, que fueron torturados en virtud de sus creencias religiosas. Como queda de manifiesto, la multiplicidad de hechos denunciados resulta inmensa. Algunos de ellos fueron, además, la cruda consecuencia de intolerancia religiosa y antisemitismo imperantes en las cúpulas de mando de las Fuerzas Armadas argentinas. 
Este modo de actuar que se describe en muchos testimonios, y que constituyó una práctica reiterada, constituye sin lugar a dudas una forma de maltrato incuestionablemente cruel, brutalmente inhumano y degradante, que debe ser calificada con el término tortura.

\section{6.- El trámite ante la Comisión Interamericana de Derechos Humanos}

La petición P-460/15 (“Centro de Excombatientes Islas Malvinas La Plata P-46015 Argentina") se interpuso en el año 2015, luego de que la Corte Suprema de Justicia de la Nación declarara inadmisible la queja interpuesta por el organismo, circunstancia que consolidó el sobreseimiento y la declaración de prescripción operada por la Cámara Nacional de Casación Penal en beneficio de una de las personas denunciadas en el expediente.

En ella se solicitó a la CIDH que declare la responsabilidad del Estado argentino por la vulneración de los artículos 8 y 25 en relación con el artículo $1^{\circ}$ de la Convención Americana de Derechos Humanos, como así también la conculcación de los artículos XVIII y XXIV de la Declaración Americana de los Derechos y Deberes del Hombre, y del Derecho a la Verdad, íntimamente relacionado a los artículos mencionados.

Las aludidas violaciones de derechos emergieron, tal como se ha consignado en los capítulos precedentes, tras la conculcación del Derecho a la Vida, artículo $4^{\circ}$ de la Convención Americana, el Derecho a la Integridad Personal, consagrado en el artículo 5.1 y en el artículo 5.2 de la Convención Americana, como así también, del Derecho a la Salud consagrado en el artículo XI de la Declaración Americana y los artículos 1, 2, 3, 4, 5 y 6 de la Convención Interamericana para Prevenir y Sancionar la Tortura.

En este punto resulta central remarcar que, si bien el caso que motivó la presentación es individual, es decir, se llega por Taranto luego de la inadmisibilidad decretada por la CSJN, se solicita la declaración de responsabilidad del Estado por todos los denunciantes (a la fecha 120), dado que, a 37 años de finalizada la guerra de Malvinas (14/6/1982), y 12 de iniciada la causa (2007), aún no se han constatado instancias procesales significativas en aras de consagrar la verdad y la justicia.

Actualmente la Petición se halla bajo estudio para el eventual dictado de su admisibilidad. 


\section{Nota de campo 6: Reunión de trabajo ante la CIDH}

Lunes 7 de mayo de 2018. 14:30 horas. Hotel Crowne Plaza Santo Domingo, República Dominicana. Luego de mucho esfuerzo, y una campaña para reunir fondos, logramos presentarnos a la reunión de trabajo en el marco del 168 período de sesiones de la CIDH, tras la apertura del proceso de solución amistosa propuesta por la República Argentina. Con anterioridad al viaje habíamos remitido 12 puntos sobre los que queríamos conversar para, eventualmente, arribar a un acuerdo.

La comitiva del CECIM la integramos Laurentina, Ernesto y yo. Llegamos unos días antes a República Dominicana. A la hora señalada asistimos a la audiencia. Lo primero que llamó nuestra atención fue la despersonalización del proceso. Teníamos asignado un cubículo, que pudimos consultar en la entrada y, hasta la hora prevista, no se presentó nadie. A las 14:30 en punto se acercó un funcionario de Cancillería argentina, Salgado, el Comisionado y Relator de la CIDH para Argentina, Luis Ernesto Vargas Silva junto a una asistente.

Allí tuvimos la primera sorpresa. La Dirección de Litigio Internacional de la Secretaría de Derechos Humanos de la Nación, en ese momento a cargo de Ramiro Badía, no se había presentado. Se comunicaron vía Skype. Recuerdo el asombro. Nos había costado mucho llegar hasta allí. Todo, desde el organismo, constituye un gran esfuerzo.

Luego de iniciada la reunión, comenzaron los entredichos. Sentimos que Badía estaba improvisando. Nos habló de pensiones vigentes para excombatientes, a lo que retrucamos que la petición era por violación a los derechos humanos y que bajo ningún punto de vista podían considerarse las pensiones como parte de una política de reparación. También sostuvo que no podía darse la asunción de responsabilidad por parte del Poder Ejecutivo porque ello implicaría vulnerar la separación de poderes. A ello respondimos que no pedíamos condenas, ni mucho menos. La petición a la CIDH versaba sobre privación a la tutela judicial efectiva, y que la Dictadura había producido documentación, había indicios y testimonios que daban la pauta de que se habían cometido dichas violaciones a los derechos humanos, y que nada se había hecho para cumplir con la obligación de investigar. Llevábamos 11 años de causa y 36 años de finalizada la guerra.

No hubo acuerdo. Sí una discusión fuerte. Vargas Silva intervino para concluir un debate que, sin lugar a dudas, no llevaría a ningún puerto, y se comprometió en persona a trabajar para acercar posiciones. 
Nos fuimos enojados/as. Al punto que, recuerdo, Ernesto quiso pedir un taxi para regresar al departamento y, Laurentina y yo, le respondimos al unísono que queríamos volver caminando. Necesitábamos esa caminata. El calor de Santo Domingo nos golpeó. No recuerdo la distancia pero deben haber sido unas veinte o treinta cuadras. Aún hoy recordamos el sudor con el que llegamos al departamento.

Tiempo después, el Estado desistió de continuar con el proceso de solución amistosa. La propuesta de concluir con dichas negociaciones la esbozó Badía.

\section{7.- ¿Qué documentación sobre Malvinas produjeron las Fuerzas Armadas?}

La presente investigación se afinca, principalmente, en la evaluación de la vasta documentación existente en torno a la cuestión Malvinas, en concreto, al conflicto armado del Atlántico Sur.

A los fines de abordar su objeto, o dar respuestas ( $j$ o formular nuevos interrogantes!) a las múltiples preguntas que guían la producción, es importante comprender qué tipo de documentación ha sido desclasificada, para luego realizar un recorte y conformar, finalmente, el corpus sobre el que se realizará un análisis pormenorizado.

Sólo así se puede ubicar las piezas específicas dentro de un frondoso acervo archivístico. En este punto, resultan de suma importancia el Informe realizado por el Ministerio de Defensa (Informe Ministerio de Defensa), como también el Informe producido por el equipo de investigación de la Facultad de Ciencias Sociales - UBA, a cargo de Cora Gamarnik y María Laura Guembe (2018).

A continuación, se lista la documentación por Fuerza:

a.- Ejército:

La documentación que se listará a continuación obra en distintas dependencias de la Fuerza como el Servicio Histórico del Ejército, Dirección General de Salud y Departamento de Veteranos de Guerra. A su vez, se utilizará el criterio propuesto por los equipos del Ministerio de Defensa de la Nación, a saber: documentación del conflicto (previa, durante y posterior a la guerra) y documentación de comisiones e informes. (Ministerio de Defensa de la República Argentina, n.d.)

a.1.- Servicio Histórico del Ejército: documentación del conflicto 
-Colección de Diarios de Guerra

-Colección Personal:

Esta colección es central para el curso de la presente investigación, pues contiene información vinculada al regreso del personal que participó en el Teatro de Operaciones del Atlántico Sur (TOAS). Aquí se encuentran las Actas de Recepción que son analizadas puntualmente.

\section{-Colección Inteligencia}

Esta colección también resulta nodal para el desarrollo de la investigación. Sobre todo, en lo que concierne a Inteligencia, Contrainteligencia, Acción Psicológica.

-Colección Operaciones

-Colección Logística

-Colección Informes sobre Experiencias

a.2.- Servicio Histórico del Ejército: documentos de comisiones e informes de la Fuerza que analizan el conflicto

-Colección Comisiones de Evaluación (Calvi - Rattenbach)

-Colección Informe Oficial del Ejército

-Colección Comisión Especial Malvinas (CEM)

a.3.- Otros documentos del Ejército

-Libro histórico

-Actuaciones de Justicia Militar (AJM)

-Legajos

-Libros de Juntas de Calificación

b.- Armada:

La documentación que se lista a continuación obra en distintas dependencias de la Fuerza.

-Fondo Documental Malvinas

-Informe Final de la Comisión de Acciones de Combate

-Informe Operaciones Atlántico Sur 


\section{-Informe Operación Rosario}

-Otros documentos que integran el Fondo Documental Malvinas (audios, cartas náuticas, calco, croquis, diario de guerra, entrevistas y declaraciones, filminas, fotografías, mapas sinópticos, material audiovisual, entre otros)

-Documentación General del Archivo ARA vinculada al Conflicto del Atlántico Sur (legajos de personal, actuaciones de justicia, entre otros)

-Ejemplo de relevamiento transversal de datos: operación ALFA c.- Fuerza Aérea:

La documentación que se lista a continuación obra en distintas dependencias de la Fuerza.

-Dirección General de Estudios Históricos (compilación "Fondo Malvinas”)

-Informes Finales producidos por la Fuerza Aérea

-Colección brigadier general Carlos Alberto Rey (integrante CAERCAS)

d.- Documentación producida por otros organismos:

- Ejército Argentino - Informe Jefes de Unidades

-Informe Islas Malvinas, Georgias del Sur y Sandwich del Sur: antecedentes, hechos ocurridos y decisiones adoptadas desde diciembre de 1981 hasta junio 1982

-Informe sobre el conflicto del Estado Mayor Conjunto (EMC)

-Informe del Comandante de la Agrupación Naval Antártica

-Reseña histórica de operaciones militares y conclusiones del Informe Calvi

-Doctrina militar referente al conflicto

-Documentación producida durante el conflicto

-Cartografía y gráficos

-Fotografías

-Audios 


\subsection{1.- Archivos desclasificados relativos al conflicto bélico del Atlántico Sur: actas de recepción}

Estos documentos estaban destinados a la recepción y consecuente control del personal que regresaba de las Islas. Las mismas consistían en un formulario tipo a ser completado por el personal que arribaba de Malvinas.

Se elaboraron dos tipos de actas de recepción. Una, con campos destinados a datos personales, otros a la experiencia en Malvinas y en el final, la referencia a los anexos. El Informe del Ministerio de Defensa (Informe Ministerio de Defensa), elaborado por el equipo de desclasificación de archivos de dicha entidad, da cuenta de qué información contienen los mentados anexos:

Anexo 1: Experiencias recogidas en el TOAS (sólo para personal superior) - a responder por Oficiales.

Anexo 2: Información personal fallecido, herido, desaparecido y PG a responder por $S / C$, Suboficiales y Oficiales.

Anexo 3: Actos destacados. Observaciones, (lugar, fecha, hora, relato, etc.) - a responder por $S / C$, Suboficiales y Oficiales.

Anexo 4: Aspectos de interés para agregar (exclusivo cuadros) - a responder por Suboficiales y Oficiales. (Ministerio de Defensa de la República Argentina, n.d.: 63) 

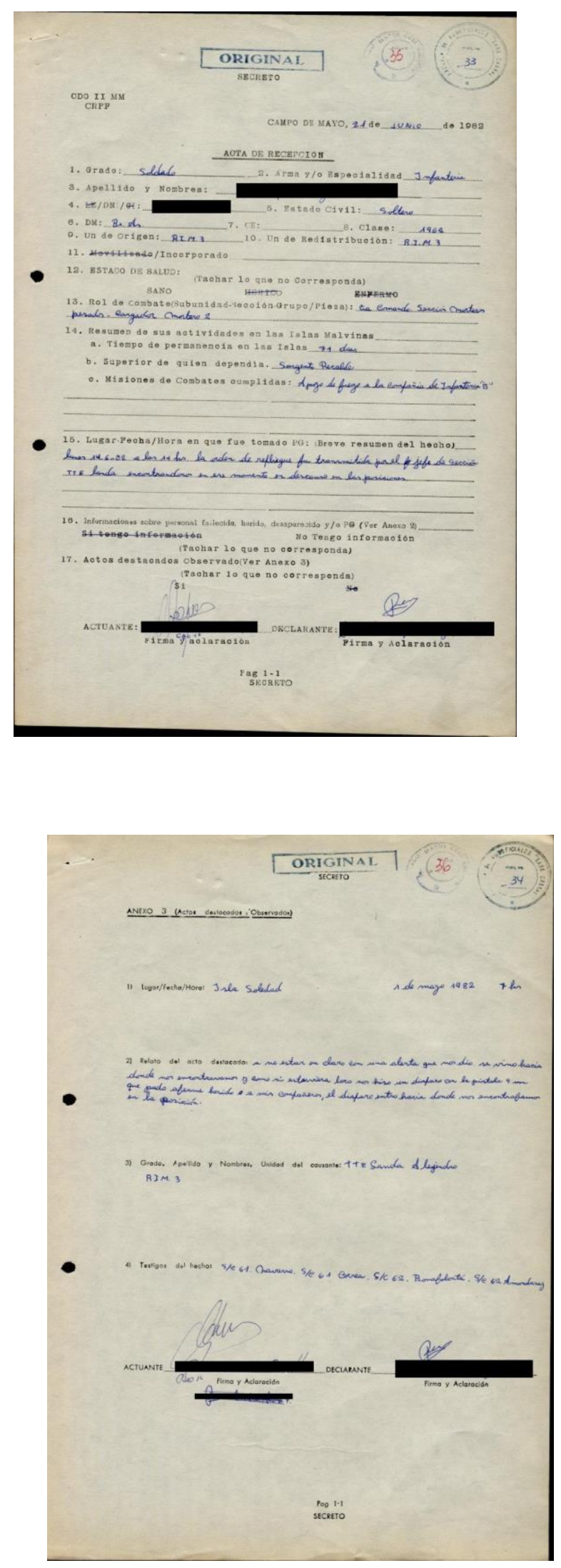

En las actas de recepción cuyas imágenes se adjuntan (Personal, Caja12, CAR 1) se aprecia con claridad cómo estaban estructuradas. A su vez, en el ANEXO 3, se lee " $a$ 
no estar en claro con una alerta que nos dio, se vino hacia donde nos encontravamos y como si estuviera loco nos hiso un disparo con la pistola $9 \mathrm{~mm}$ que pudo aberme herido o a mis compañeros, el disparo entro hacia donde nos encontrabamos en la posicion".

Este tipo de relatos y descripciones, son usuales en las actas. Son precisamente la falta de investigación, juzgamiento, y falta de sanciones, a las que se añaden las acciones de inteligencia y las órdenes (como la brindada por el Comandante en Jefe del Ejército, Cristino Nicolaides) las que motivaron la labor investigativa.

Continuando con las actas, éstas fueron los instrumentos por los que se recopiló la información del personal proveniente de Malvinas, y se sistematizó la situación del personal de baja.

A su vez, se hallaron otras actas de recepción, confeccionadas para exprisioneros de guerra.

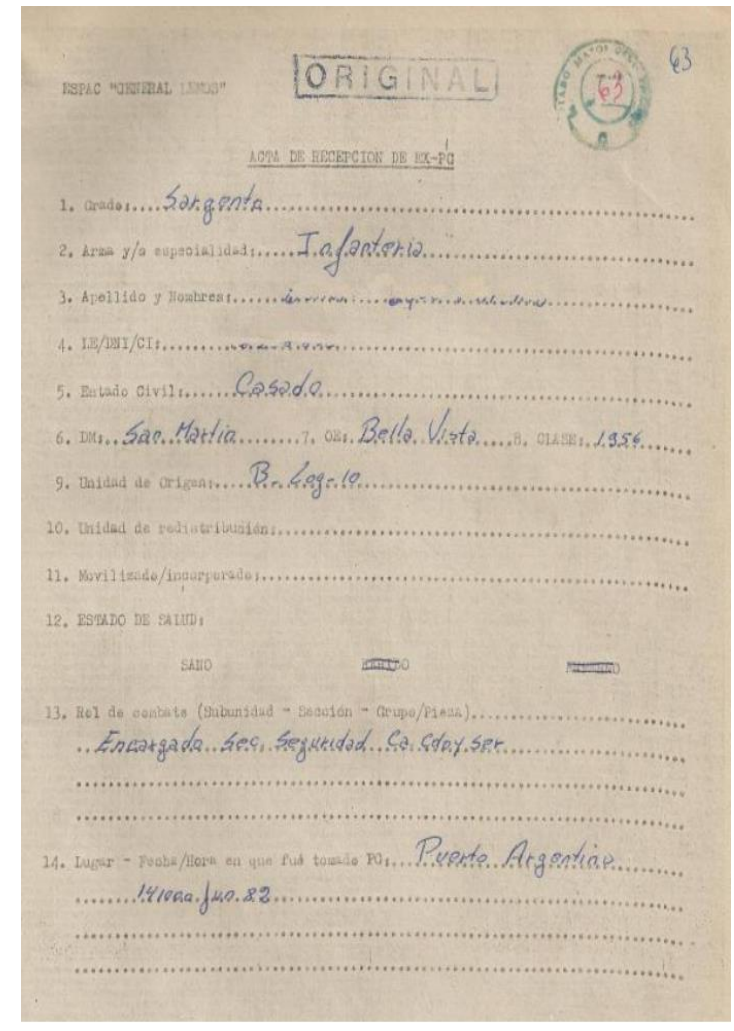

Como puede apreciarse, las Fuerzas Armadas produjeron información oficial, y en ella comenzaron a quedar plasmadas las denuncias de torturas. Esto cobra especial relevancia para proceder a efectuar una lectura sobre las acciones tomadas durante y al 
finalizar la guerra, por las que sostengo se instrumentaron las tecnologías del ocultamiento (o tecnologías de la impunidad).

\subsection{2.- Archivos desclasificados relativos al conflicto bélico del Atlántico Sur: el montaje de la impunidad}

Como se ha visto, la guerra de Malvinas ha sido un capítulo más de la dictadura cívico/militar argentina, circunstancia que redunda en que los dispositivos de gestación de impunidad mantuvieran rasgos invariables con los hechos que sucedieron en el período 1976/83 en territorio continental.

De esta forma, se aprecia lo que a priori podría ser caracterizado como una estrategia de comunicación externa, que incluye el diseño específico de las piezas y contenidos a difundir por el Estado Mayor Conjunto de las Fuerzas Armadas, así como el contralor sobre las publicaciones de los medios de comunicación; y una estrategia interna, con ribetes de manipulación psicológica, destinada a introyectar temor y un único discurso en los soldados conscriptos. El vector que atraviesa el montaje aludido es la "seguridad nacional", categoría difusa, de contenido castrense cuya vaguedad habilitó los márgenes de discrecionalidad por parte de los artífices de la Dictadura.

Así, puede citarse el "Acta disponiendo el control de la información por razones de seguridad nacional”, en el que la Junta Militar resolvió:

Art. Iro-Todos los informes y noticias del exterior, cualquiera sea
su procedencia y medio utilizado y toda información relacionada
con aspectos que hacen al desarrollo de las operaciones militares y
de la seguridad nacional quedan sujetos al control del Estado
Mayor Conjunto, previo a su difusión por los medios informativos,
sean estos radiales, escritos o televisados. (Personal, Caja 21,

Carpeta 2)

A su vez, la misma orden, firmada por Galtieri, Anaya y Lami Dozo, hacía responsables personalmente a Directores y Editores de los medios, y disponía, frente a la 
infracción, la clausura y la detención y puesta a disposición del Poder Ejecutivo Nacional de los mismos (Personal, Caja 21, Carpeta 2).

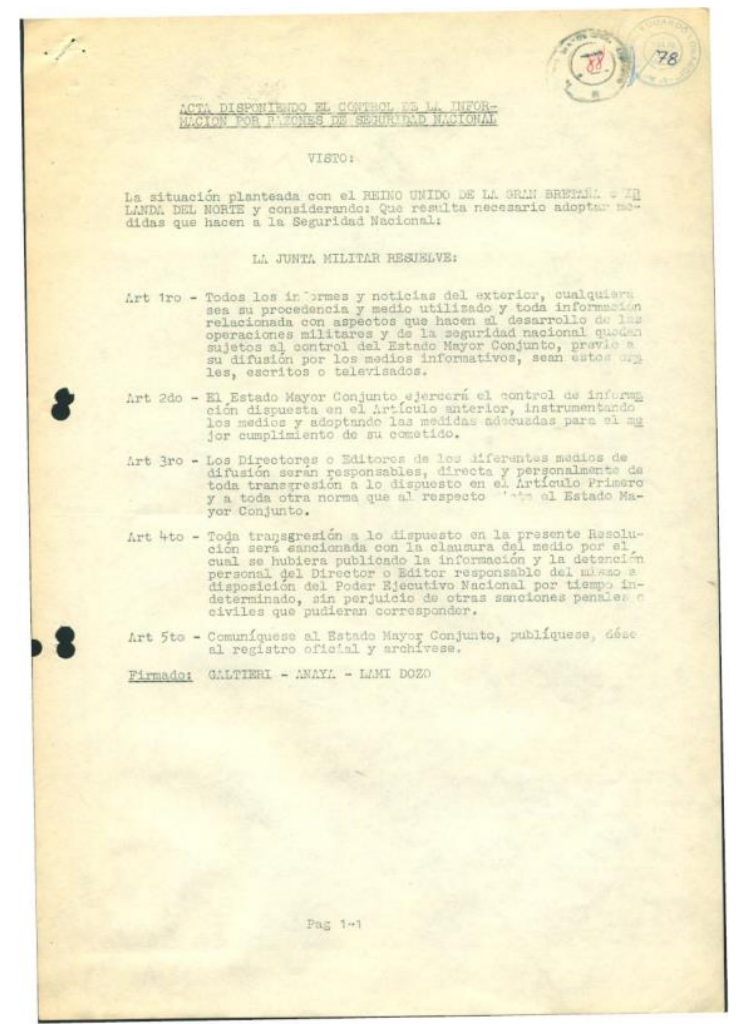

En lo que concierne a la estrategia individual o psicológica, cobra especial relevancia el "Informe de experiencias" del 8 de junio de 1982, en el que el Jefe de la Sección de Inteligencia del CARI, el Teniente $1^{\circ}$ Ramón Antonio Ojeda, eleva una serie de lineamientos al Jefe del Destacamento de Inteligencia 201. En concreto, se giran documentos confeccionados a instancias de las entrevistas individuales al personal internado en el CARI.

En el punto 3, bajo el título "Acción Sicológica” el documento expresa:

Las actividades de acción sicológica [SIC] no han sido implementadas en forma masiva, sino a nivel individual, pero aún cuando se logren efectivizarlas a nivel de masas, se aprecia que su resultado no será el esperado en razón de: 
b. El personal entrevistado en un porcentaje elevado, con el más alto índice entre los soldados, no desea volver al frente de batalla, manifestando esto en razón de que:

1. Aprecian existe gran desorganización y errores de conducción por parte de los Oficiales, que les ha costado heridos y muertos entre sus camaradas.

2. El mal trato recibido por parte de los Suboficiales, quienes en muchos casos llegan a esconder comida o a tomar mayor parte que la que le corresponde, en detrimento de los soldados e incluso algunos manifiestan haber recibido castigos corporales al intentar quejarse por esta situación. (Comisión Especial Malvinas, Caja 1, Carpeta 4).

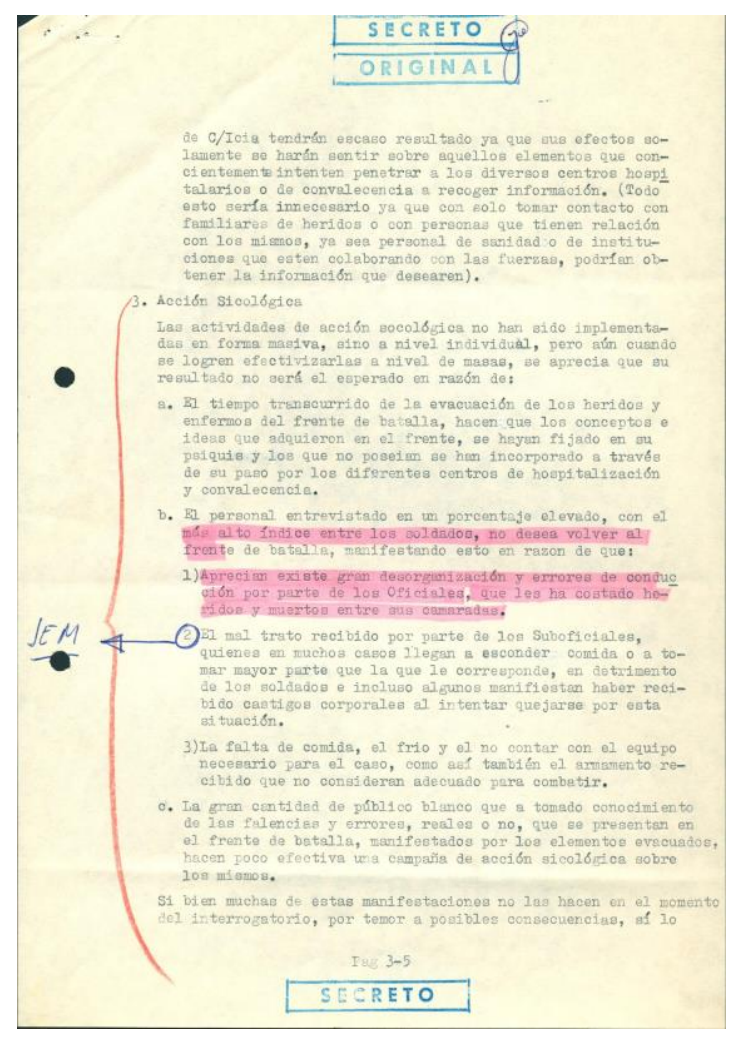

A partir de allí, dentro de las proposiciones, se dispone:

\section{Acción Sicológica}

Se implementaría una campaña de Acción Sicológica preventiva a nivel individual sobre los internados en dicho Hospital de manera 
que al ser evacuados, se evite el efecto "bola de nieve" que trae como consecuencia los comentarios por ellos realizados.

Así también será quizás lo más importante, la puesta en conocimientos a los Comandantes o Jefes de los comentarios o declaraciones hechas por sus subordinados, a fin de que adopten las medidas que crean convenientes para solucionar o prevenir hechos que afecten a la moral o a las operaciones. (Comisión Especial Malvinas, Caja 1, Carpeta 4).

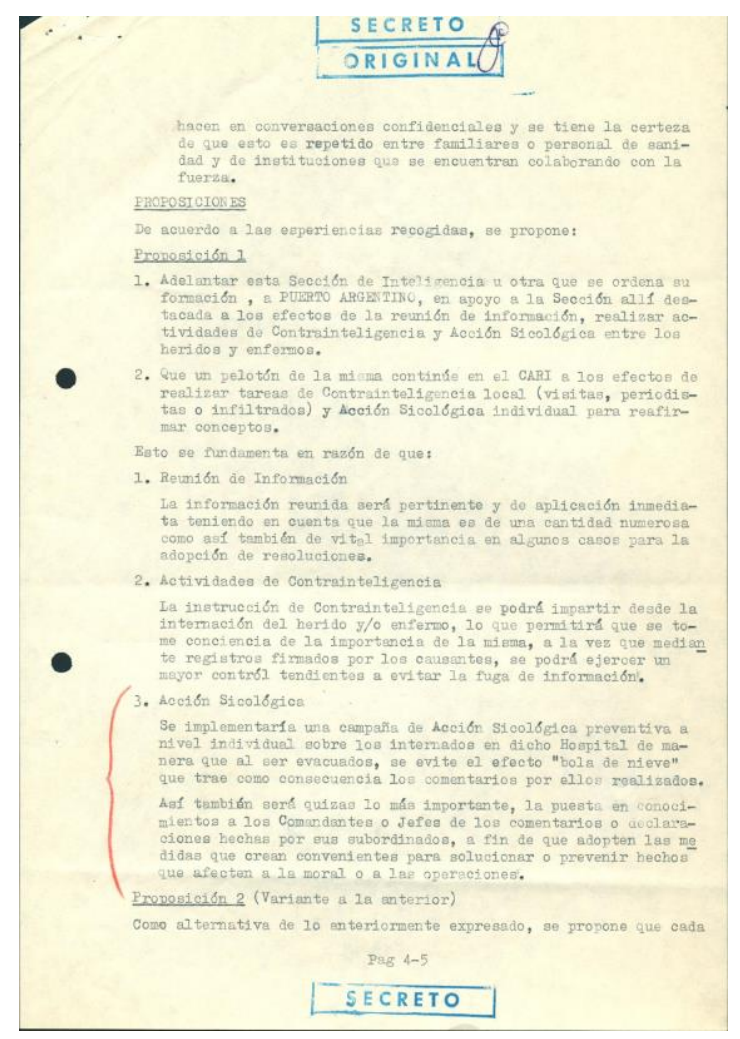

Como se aprecia, estamos ante el diseño de un dispositivo tendiente a consagrar la impunidad (tecnologías de olvido o tecnologías de impunidad) frente a la emergencia de relatos que comenzaban a dar cuentas de aquello que, a posteriori, se puede aprehender de la lectura de las conclusiones del Informe Rattenbach. En dicho sentido, el 14 de junio de 1982 el Comando Cuerpo del Ejército elevó la Orden Especial N²2/82, en la que se instituye el Centro de Recuperación de ex Prisioneros de Guerra, y se ordena la adopción de medidas de contrainteligencia, entre las que se hallan la "prohibición a todo el personal de efectuar declaraciones y/o presentarse a reportajes por los medios de comunicación social" (SHE, Personal, caja 36, carpeta 5, foja 6). 
En consonancia con lo expuesto, es importante hacer mención a las medidas de inteligencia y contrainteligencia estipuladas por la Orden Especial $\mathrm{N}^{\circ} 4 / 82$ del Jefe del V Cuerpo Comando del Ejército, adoptada el 19 de junio de 1982, "Para repliegue y desmovilización". Su Anexo 1, en el que se adoptaron las "Medidas de Inteligencia y Contrainteligencia", establece la llamada "Seguridad del Personal".

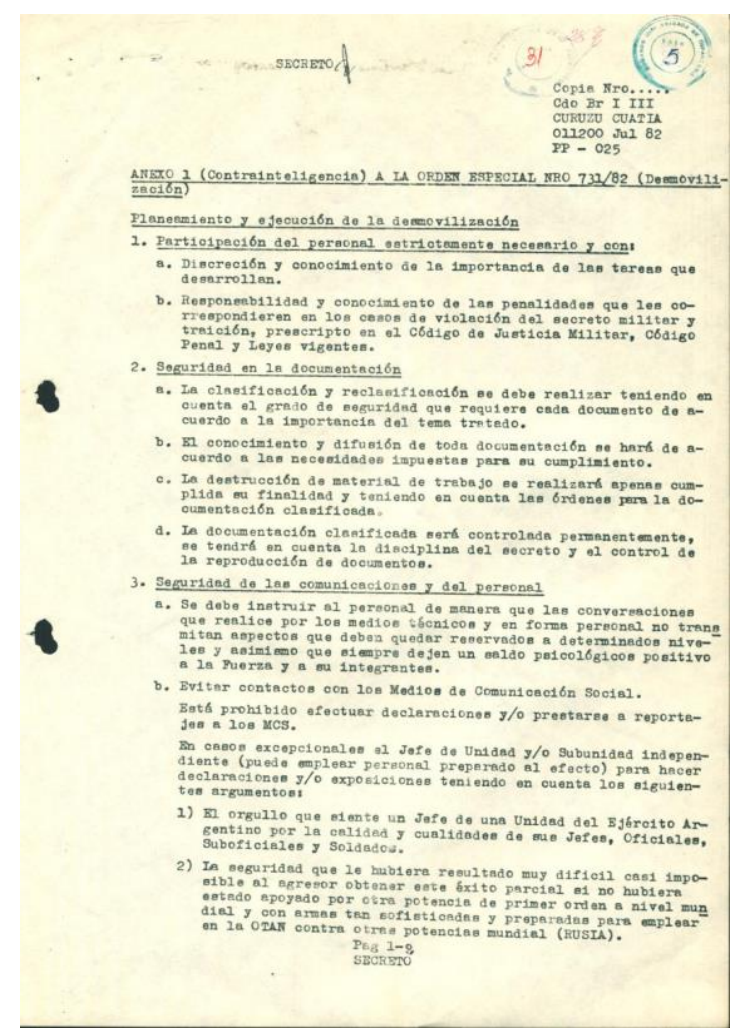




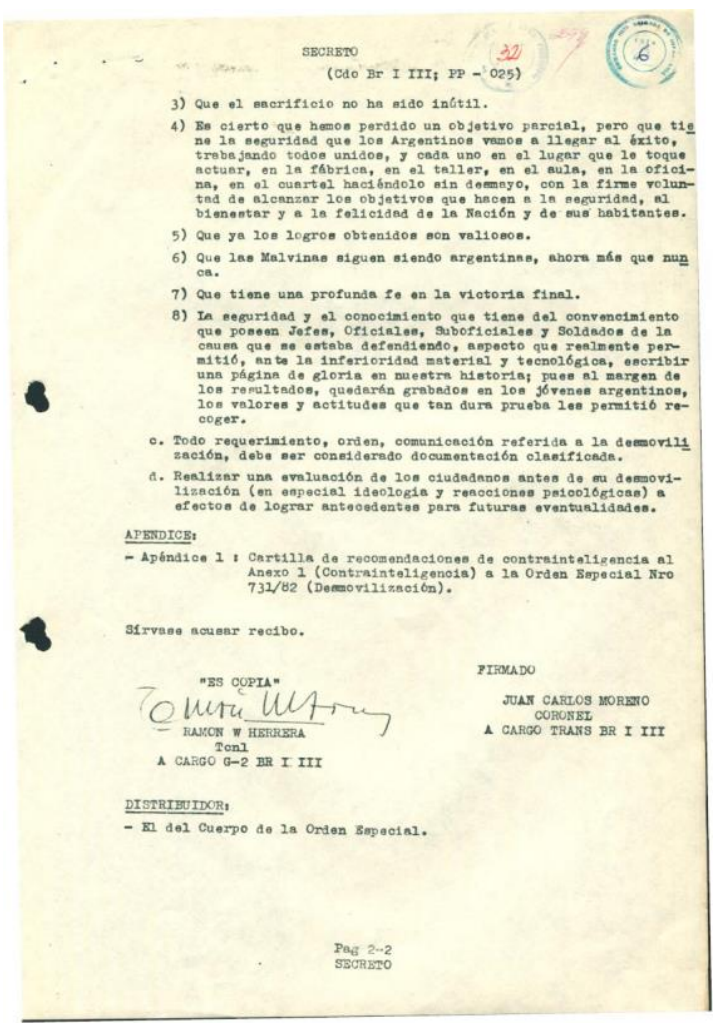

A su vez, se estipuló que los medios de comunicación social debían proporcionar información previamente fiscalizada y que no vulnerara normas de contrainteligencia. El Apéndice 1 propone una "Cartilla de recomendaciones de contrainteligencia":

\section{ARGENTINO!!!}

(...) USTED luchó y retribuyó todo lo que la PATRIA le ofreció: el orgullo de ser ARGENTINO.

Ahora la PATRIA le requiere otro

esfuerzo, de ahora

en más USTED deberá:

---NO proporcionar información sobre su movilización, lugar de presentación, arma a que pertenece $y$ lo aptitud adquirida y su experiencia de combate.

--- NO ser imprudente en sus juicios y apreciaciones.

---NO dejarse llevar por rumores ni noticias alarmantes.

$\begin{array}{clcc}\text {--- Recordar } & \text { que } & \text { TODOS debemos } & \text { perpetuar } \\ \text { la forma } & \text { heroica como nuestros soldados }\end{array}$



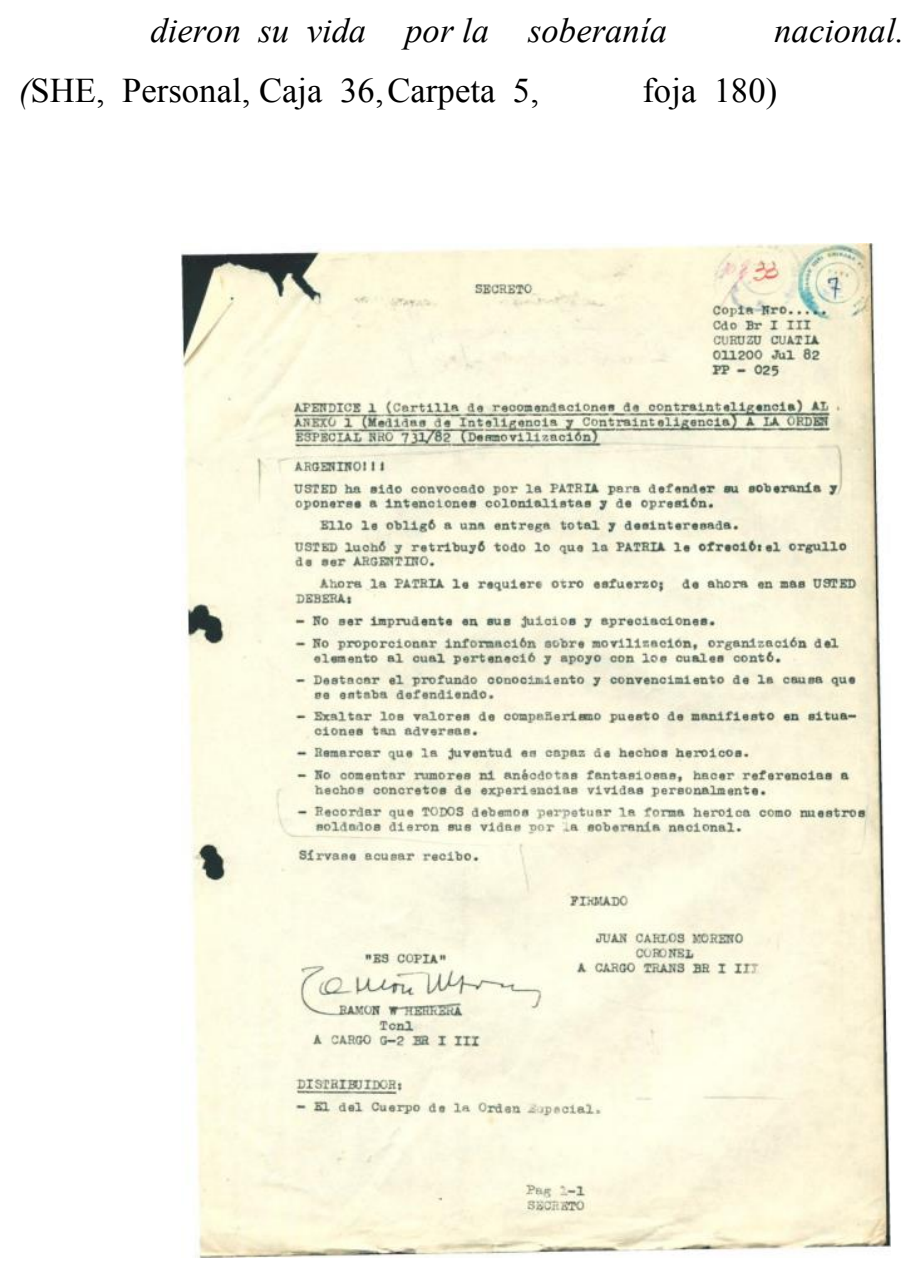

Como se ha mencionado, esta trama de acciones de inteligencia $y$ contrainteligencia, cuya institucionalización se edificó a instancia de los Centros de Recuperación de Ex Prisioneros de Guerra (CREPG), de los Centros de Apoyo a la Recuperación Integral (CARI) y de los y de los Centros de Recuperación del Personal de la Fuerza (CRPF), arrojaron como resultado la proliferación de denuncias a propósito de las torturas, la no provisión de alimentos a pesar de la disponibilidad de los mismos, los malos tratos, entre otras cuestiones. La respuesta a estas manifestaciones, vino de la mano de una orden fechada el 30 de diciembre de 1982 y firmada por el entonces Comandante en Jefe del Ejército, Cristino Nicolaides. Allí, dispuso que:

En los casos del anterior punto 1. [habla de las torturas], en que se acreditare alguna infracción, las respectivas resoluciones no excederán el ámbito disciplinario, dentro de pautas de mesura, guardando la adecuada reserva... y añade que [c]uando excepcionalmente, se apreciara que el hecho no se puede resolver 
en el ámbito disciplinario, deberá informarse tal circunstancia dándose debidamente razón de ello, al Comandante en Jefe del Ejército, quien decidirá sobre el particular (Sección Comisión de Evaluación, Caja 2, Carpeta 15, Fojas $\mathrm{N}^{\circ} 1$ y 2)

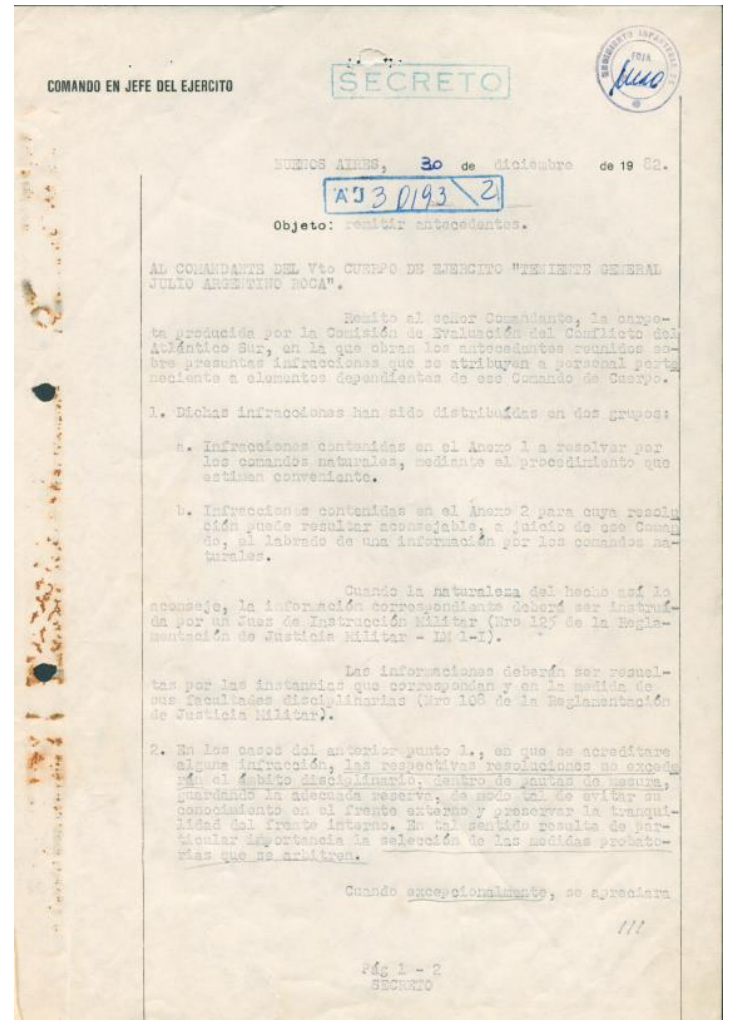




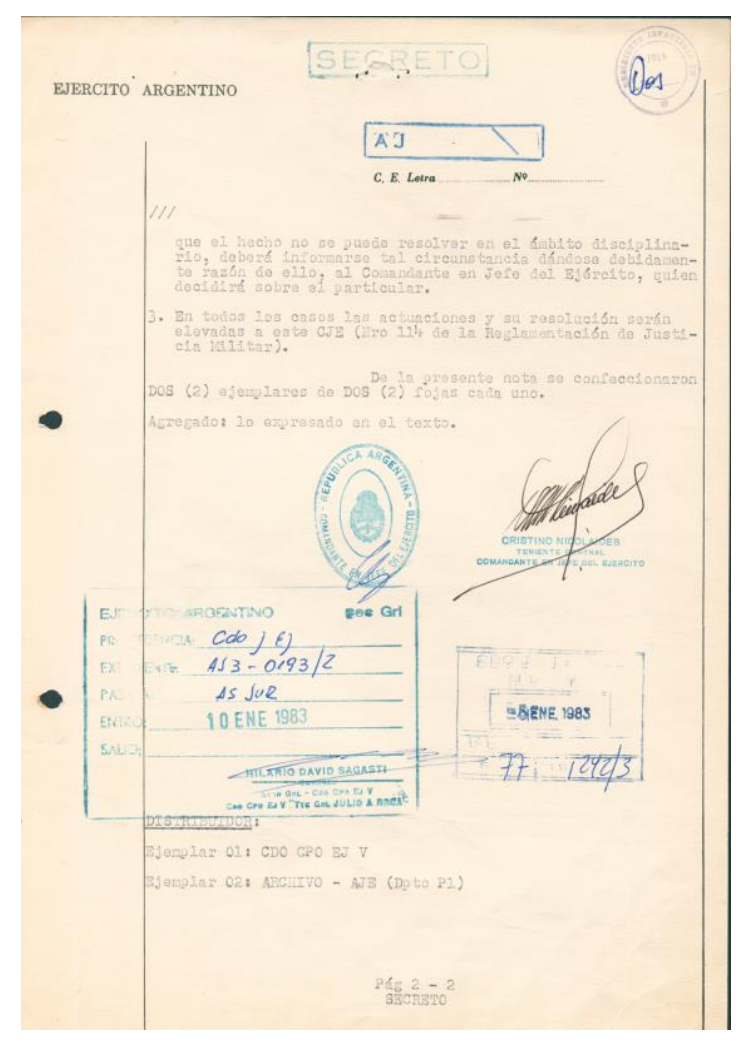

Resultan muy interesantes las conclusiones del II Informe Malvinas - Relevamiento Ejército, elaborado por el Equipo de Relevamiento y Análisis de los Archivos del Ejército de la Dirección de Derechos Humanos y Derecho Internacional Humanitario, dependiente del Ministerio de Defensa, durante el mes de noviembre de 2016.

Allí, el mentado equipo propone algunos casos a modo de ejemplificación de los efectos de la orden de Nicolaides. Entre ellos, se consigna un documento elaborado por el Comandante de la IIIra Brigada de Infantería, Braulio Argentino Sánchez Ávalos, quien encargó la elaboración de informes a sus Unidades dependientes, a los efectos de investigar las presuntas infracciones cometidas.

El Jefe de Regimiento de Infantería 4 (RI 4)m tcnl Jorge Eusebio REARTE recomendó, el 10 de abril de 1983, que "se reserven estas actuaciones para constancia y no se tome ninguna medida discplinaria” por lo siguiente:

A. porque se resentirá el frente interno. 
B. porque trascenderá al frente externo, aun cuando se tomen adecuadas medidas de seguridad, con el agravante que todo será distorsionado para ser luego en forma insidiosa dirigido en contra de la Fuerza. (Comisión de Evaluación, Caja 2, Carpeta 9, Foja Nº 5)

(Equipo de Relevamiento y Análisis de los Archivos del Ejército, 2016a)

Tiempo después de haber permanecido en los CARI, se dispuso que los soldados conscriptos regresaran a sus Unidades de origen, o bien fueran dados de baja. En este contexto se dictó la Orden Especial Nro 763/82 "Para el apoyo a ex combatientes del Ejército en Malvinas", entre cuyos fines se encontraba el de "5) Negar espacio a las organizaciones subversivas y a los sectores adversos a la Fuerza." (Equipo de Relevamiento y Análisis de los Archivos del Ejército, 2016a: 12).

Como bien consigna el Informe del Ministerio de Defensa citado, la Orden 763/82 fue complementada por la Orden 778/83 "Para la creación del Departamento VIII Apoyo a Ex Combatientes del Ejército", con la finalidad de

disponer de un elemento orgánico de la Fuerza centralizador de los requerimientos, ofrecimientos, necesidades de los ex combatientes y sus familiares, como así también para la vinculación y control de las distintas organizaciones (Equipo de Relevamiento y Análisis de los Archivos del Ejército, 2016a: 12)

A su vez, se ordenó que la Jefatura II de inteligencia proporcione

\footnotetext{
"información sobre ideología de organizaciones de apoyo a combatientes" y "coordinar la acción sicológica especifica" (Equipo de Relevamiento y Análisis de los Archivos del Ejército, 2016a: 13)
}

Por su parte, el Informe del Ministerio de Defensa da cuenta de la Orden Especial del Comandante en Jefe del Ejército Nro 783/83 que creó el "Sistema de apoyo a ex 
combatientes del Ejército en las Malvinas", con la que se buscó implementar un Sistema de Apoyo impartido en la Orden Especial Nro 763/82. Una de sus misiones del Sistema consistía en

apoyar a las organizaciones de ex combatientes de cada jurisdicción previa evaluación de sus posibles implicancias políticas (Equipo de Relevamiento y Análisis de los Archivos del Ejército, 2016a: 13)

Resulta indispensable apreciar las consecuencias de este sistema. A la hora de llevar adelante la desclasificación, digitalización y sistematización de todo el acervo documental relativo al conflicto bélico del Atlántico Sur, el Equipo de Relevamiento y Análisis de los Archivos del Ejército, halló un Informe confeccionado por la Comisión Especial Malvinas el 21 de diciembre de 1989. El mismo responde a la publicación del “informe Rattenbach, el drama Malvinas", por parte del Centro de Ex Combatientes Islas Malvinas La Plata (CECIM).

En el Anexo 2 consta un informe de inteligencia sobre dicha organización, se registra la constitución para 1982 y la finalidad: de nuclear a los ex combatientes y brindarles apoyo sicológico, laboral y jurídico. La tendencia ideológica es definida como "izquierdista, y en tanto tal cuenta con el apoyo de partidos de izquierda, organizaciones de solidaridad y entidades de derechos humanos". Hay además un análisis de los antecedentes de cada uno de los integrantes del Consejo Directivo como también de las diferentes actividades que realizaron. (SHE, CEM, Caja 3, Carpeta 13) (Equipo de Relevamiento y Análisis de los Archivos del Ejército, 2016a: 13-14)

A todo lo expuesto debe añadirse el diseño de campañas de acción psicológica tendientes a promover una semiosis que permitiera instalar la ineludible necesidad de llevar adelante la guerra de Malvinas, y también resaltar también el heroísmo de las Fuerzas Armadas. 
La guerra en las Malvinas se inscribió en la construcción de una narrativa que centra la identidad nacional en las guerras, como uno "de los sacrificios realizados para obtener los objetivos nacionales":

A. Las dos invasiones inglesas y la posterior reconquista de Buenos Aires.

B. Las campañas del Alto Perú y la exitosa Campaña de los Andes.

C. Las campañas para la integración territorial de la Patagonia y el Chaco.

D. La Lucha Contra la Subversión.

Para el caso de los medios de comunicación y relacionado con las campañas de AS se propuso la aparición de comunicadores claves "a cargo de Generales retirados en los programas televisivos de mayor audiencia del País, tales como "Tiempo Nuevo” (Canal 7), “Telepolítica” y "Periodismo Puro” (Canal 9), etc. Complementándose con "entrevistas a combatientes, heridos, con el objetivo de destacar hechos”. Se estableció también la necesidad de desarrollar una "Campaña para impedir que la subversión capitalice a su favor el dolor y/o resentimiento de los familiares de nuestros soldados muertos y desaparecidos en la guerra de Malvinas". (SHE, CEM, Inteligencia, Caja 7, Carpeta 1) (Equipo de Relevamiento y Análisis de los Archivos del Ejército, 2016a: 15-16)

Resulta innegable el impacto que todo este andamiaje estatal ha generado en la población de excombatientes. En dicho sentido, a 38 años de finalizada la guerra, las condiciones para el imperio de la impunidad siguen vigentes. Es importante remarcar que el Estado que diseñó estas acciones fue el mismo que desde 1976 instauró a sangre y fuego el horror. Ese Estado primero llevó a los conscriptos a una guerra ilegítima, para luego imponerles el silencio.

\section{8.- Testimonios. El fin de la guerra y la imposición de silencio}

Hasta aquí hemos tratado las torturas cometidas por miembros de las Fuerzas Armadas argentinas en perjuicio de los soldados conscriptos. También, y a instancias de 
la documentación oficial, cómo el Estado terrorista implementó mecanismos de acción psicológica tendientes a consagrar la impunidad (concepto central en el desarrollo de la investigación, expresado en el sintagma tecnologías del ocultamiento).

Resta entonces apreciar cómo impactaron dichas lógicas en la subjetividad de las víctimas. En casi una década de trabajo con ellas, he podido percibir la importancia del accionar estatal en lo concerniente a las dificultades que emergieron para avanzar en el proceso de Verdad y Justicia.

La idea de "no hablar" está presente, como un fantasma que cruza en forma transversal la experiencia vital de las personas. Romper el imperativo de silencio, vencer la lógica castrense, deconstruir los relatos erigidos sobre la noción del héroe, como también a partir los relatos históricos de la gesta heroica, constituye sin lugar a duda uno de los desafíos más trascendentes a los que nos hemos enfrentado.

No es casual que a 38 años de finalizada la guerra, no se hayan sustanciado los juicios (más allá de lo mucho que se ha avanzado, circunstancia que se abordará más adelante). Para ello, como se puntualizó al momento de trazar las líneas metodológicas, resultan indispensables los testimonios.

Éstos son oficiales. Constituyen denuncias realizadas por las víctimas. Son el anclaje de la investigación penal que se despliega en Río Grande, Tierra del Fuego, Antártida e Islas del Atlántico Sur. Tal como se aclaró con carácter previo, la identidad de las personas que se citarán a continuación es suplantada por una sigla que no permita su identificación directa ${ }^{37}$ (no así los nombres de las personas denunciadas).

Como se ha visto, $\mathrm{AB}$, quien sufrió en carne propia las torturas, expresó que:

\footnotetext{
Ahi estuve dos meses, en ese tiempo vienen a visitarnos algunos Suboficiales, el Sgto. González y me dicen que yo me callara la boca si no iba a tener problemas e iba a desaparecer, me dijo que yo declarara que mis secuelas fueron por una bomba de mortero, ellos querían que yo firmara algo pero no lo hice, mi madre estuvo los dos meses conmigo y Martinoli estaba en frente de mi cama, le digo a mi madre que me quiero ir, que me amenazaron, no me querían dejar ir, pero al final me dieron el alta. Agarré mis cosas y me fui,
}

\footnotetext{
${ }^{37}$ De acuerdo con lo dispuesto en la Ley 25.326 de Protección de datos personales.
} 
me fui ese mismo día para Uruguay, y por veinte años no pisé

Argentina

Por su parte, CA, que recibió golpes en sus manos y golpes propinados con un cinturón, fue testigo de estaqueamientos y otras torturas, expresa:

\begin{abstract}
llegamos a Pto.Madryn, nos devuelven los cigarrillos que nos habian sacado, en donde vamos hasta Trelew en camiones del Ejército y de ahi tomamos los Hércules hasta Palomar luego a Campo de Mayo, en donde nos dan ropa nueva, nos hacen bañar afeitar, al otro día pretendian que desfilemos, nos dijeron que lo que pasó en Malvinas quedaba entre nosotros, firmamos un acta o algo así y volvimos a nuestro regimiento.
\end{abstract}

La recurrencia de los relatos, permite apreciar que aquellas órdenes y diseños burocrático/administrativos de las Fuerzas Armadas, se tradujeron en directivas brindadas a las víctimas, y en las actas (ya abordadas), que eran exhibidas como compromiso de silencio ante la irrupción de relatos que daban cuenta de las torturas.

\begin{abstract}
llegamos a Puerto Madryn, nos iban etiquetando como soldados de guerra a medida que íbamos bajando, en Pto. Madryn los superiores nos insultan diciendo por ejemplo "por culpa de ustedes perdimos la guerra", nos suben a un camión, nos trasladan a un galpón en donde pasamos la noche y al otro día nos vamos en avión a Campo de Mayo aproximadamente el 20 de junio. Nos tienen ahí dos dias, nos engordan, nos hacen firmar un papel en donde renunciamos a todo tipo de reclamos, que estamos en aptitud física óptima, y si no firmábamos no nos daban la baja, nos vistieron con ropa nueva, nos dieron armamento y nos trasladaron a la noche a La Tablada en donde al otro día me encuentro con mis familiares. "
\end{abstract} (Testimonio DA).

Era ese Estado y no otro el que llamaba a guardar silencio. El Estado criminal, aquel que habilitó y consintió las torturas que con posterioridad pretendió dejar impunes.

Desde ahí nos llevan a la Escuela Gral. Lemos, habremos estado como dos días, nos dieron ropa nueva, nos hicieron bañar, nos 
hicieron firmar un papel, y nos dijeron que no teníamos que contar nada a nuestros familiares, de lo que habia pasado en Malvinas. Después fuimos a la Unidad de Ciudadela, al GADA, recuerdo era de noche, y fuimos en colectivos de línea. Alli me esperaba mi familia, y nos dejaron ir con mi familia. Un hecho que quiero recalcar, es que los soldados conscriptos de la clase 1963, fuimos a Malvinas, a defender la patria no habiendo jurado la Bandera, contraviniendo los protocolos, ya que nos mandaron al mes de ingresar al Servicio Militar (Testimonio de EA)

El Coronel Beliz, jefe de la Escuela de Ingenieros, me da licencia hasta la baja, al enterarse lo que me había pasado. Cuando volví me trasladaron a Campo de Mayo donde me tomaron testimonio en el Tribunal de Justicia Militar, pero no se que paso con eso, pero sí me amenazaron con que no digamos nada de lo que paso, o iba a tener problemas mi familia. Igualmente, por haber hablado, tuve amenazas, después de Malvinas. [...]

En un asado, hace dos semanas en la Escuela de Ingenieros, el Sargento Romero reconoció que me había bailado y metido en los pozos de agua. Cuando se me acerca le pongo la mano en el pecho, y le digo "que me venís a saludar?, si vos me metiste en un pozo de agua, yo te inicie una causa a vos", el me respondió que como después de 26 años le venia a decir esto, y que en ese momento le ley militar lo amparaba, era una forma de estimular a los soldados. El Sargento Romero me viene a hablar cuando estábamos comiendo, y le digo "córtala, esto decilo en la justicia”. (testimonio FA)

Las amenazas y amedrentamientos constituyen un elemento invariable de los testimonios. Ello redunda en una saturación inmediata de la muestra.

La mayoría eran heridos. Llegamos al Palomar, alli nos

hacen esperar a que se hiciera de noche, nos suben a unos micros militares y me trasladan al Hospital de Campo de Mayo. Allí estoy internado, por pie de trinchera, trastorno vasculares agudos. Allí encuentro a $A B$, que me cuenta que tenía el tabique nasal roto y una fractura de clavícula. También lo encuentro a HA, que le tenían que amputar los pies, y le habían amputado los dedos. Me trasladan al quirófano y me cortan la 3er falange del cuarto dedo del pie derecho. Estoy internado casi dos meses, durante todo ese periodo 
jamás vi a los jefes de mi regimiento, no vinieron ni a visitarme ni a ver lo que yo tenía. Una de las condiciones para darme el alta médica era que caminase bien. Me mandan al Cari, como otra dependencia, y alli me hacen firmar una declaración. Que no podía contar lo que habia pasado, luego me dan el alta y me mandan a mi casa, Esto ocurrió desde campo de Mayo y por mis propios medios, sin plata. (Testimonio GA)

Una vez en Campo de Mayo, nos hacen firmar un papel que decía que no debíamos hablar, era como una declaración que decía que “estuvo todo bien”, nos sacaron la ropa, nos dieron ropa nueva, y estuve una noche o dos, y recién al otro día me llevan a la Tablada, y el día 21 o 22 de junio, nos hacen entrega de nueva ropa y de las encomiendas que no habian llegado a las Islas. (Testimonio IA)

llegamos a Buenos Aires al Palomar ahí nos trasladan en unos micros Chevallier hacia Campo de Mayo, estuvimos dos días en los cuales entregamos la ropa y luego de distintas clases de teoría y de moral se acercaban grupos de oficiales y nos decian que es lo que habia pasado, quienes eran los ingleses, como nos encontrábamos en ese momento, que nos iban a chequear (no lo hicieron), venían las distintas guardias y nos bajaban información de lo que decir o no decir, que todo había salido bien que habiamos comido, hasta que aparecieron micros y emprendimos viaje a La Plata, nos llevan a diagonal 80 y 116 en donde la calle estaba cortada y estaban nuestros familiares, nos invitan a despedirnos de nuestros familiares para dormir la noche ahí, igualmente nos fuimos a casa, nos dicen que teníamos que volver a los cuatro días, volvimos nos hicieron firmar algunos papeles como que habíamos perdido el equipo y el armamento, nos dan el DNI y nunca más volvimos. (Testimonio JA)

Tuvimos en Campo de Mayo, ahí nos dijeron lo que teníamos que decir: "aqui no paso nada", "olvídense de lo que paso" nos hicieron firmar un papel. Yo no recuerdo que decía el papel, yo lo firme porque me quería ir a mi casa. (Testimonio KA)

Amén de las reiteraciones respecto a las "recomendaciones", "amenazas" y la firma de los papeles, los testimonios presentan el valor adicional de encontrarse georreferenciados. En efecto, permiten visualizar el sitio en el que tuvieron lugar los 
mismos, los CARI, y ubicar en qué momento sucedieron los hechos (al término de la guerra).

Previa escala es trasladado a la Escuela Sargento Cabral de Campo de Mayo.

Aqui permanece durante una semana, donde se les hace comer, higienizar, cambiar de ropa para que recuperen un buen aspecto. Antes de ser liberados fueron amenazados de que no cuenten sobre lo sucedido en las Islas Malvinas. (Testimonio de LA)

Campo de Mayo, [...] nos dieron de comer nos cortaron el pelo y a la hora de visita, nos dijeron que el que no se bañaba no recibía visita, entonces me saqué la ropa y me vi, estaba muy flaco, era un "esqueleto" y me desvanecí en la cama, quedé shockeado no me podia levantar, mis compañeros me bañaron quise salir a ver a mi familia [...] De lo flaco que estaba mi mamá no me reconocía, esa noche se fue y al otro día fuimos al Regimiento 3 nos dijeron a los compañeros de la 62 éramos los primeros que teníamos que firmar unos papeles que sino no salíamos, esos documentos decían que nos habian tratado bien que nos habian dado de comer, que no teníamos nada quereclamar al Ejercito. (Testimonio MA)

Un par de días, en camilla me llevaron a un avión hércules, y me trasladaron a Palomar, por lo que decían, y de ahí en ambulancia llegó al Hospital de Campo de Mayo, y cuando llego me tomaron los datos.

En Campo de Mayo estuve aproximadamente 2 meses. Un mes en silla de ruedas. En Campo de Mayo me hicieron injertos en los dedos. Después empezaron a llegar los periodistas, nos decían que nadie podia hablar, y hablaba el que ellos querían. Si dejaban a hablar a la gente que habian sido heridos en Malvinas, los que estaban por el pie de trinchera no podian hablar, y si sentian que hablabas mal, o si se hacia algún escrache, habia represalias. Un día yo grité que por qué no podía hablar y al día siguiente me llevaron a un pabellón solo, una habitación con una división, había una pared, y ahi me apretaron, me ordenaron que no hable de nadie, me dijeron que sabian que yo sabía mucho, y que no hablara nunca más de los militares, de lo que pasó y lo que vi, y me hacen firmar un documento. Cada tanto venían cuatro o cinco personas, 
oficiales, y me hacian firmar documentos. Yo no sabía leer ni escribir, no sé lo que firmaba. Me dijeron que me iban a hacer desaparecer, o que me iban a cagar matando. Ellos me decían que mi familia creía que estaba muerto. Ellos me daban por muerto, y de repente yo aparezco vivo, ahí.

Me dan la baja, vino un sargento de Paso de los Libres y me entregan la libreta. Luego de una semana, yo digo que me quería ir a ver a mi familia. Me hacen un chequeo médico y me dan un boleto para ir a Chaco. Cuando llego a Chaco, a la localidad de Las Breñas, me estaban esperando dos personas que según ellos eran de la SIDE, y que supuestamente los había mandado Menéndez, que yo podía visitar a mi familia pero no hablar nada de lo que pasó. Me dijeron que siempre iba a haber gente cerca de mi y que no podía estar más de dos días. Visité a mi familia, no les conté nada, les dije que me iba a ir a trabajar a Buenos Aires. Me dijeron que si hablaba me iban a hacer desaparecer. (Testimonio NA)

A la fecha, el expediente 1.777/07 en trámite ante el Juzgado Federal de Río Grande, Tierra del Fuego, Antártida e Islas del Atlántico Sur cuenta con 125 denuncias. En forma constante se incorporan nuevos testimonios que, tal vez motivados por los avances de la causa, logran vencer las imposiciones de silencio.

Soldados conscriptos, de diversas unidades militares, que fueron sometidos a torturas por agentes del Estado, fueron blanco de estas tecnologías de la impunidad. Para mayor ilustración, se acompaña la siguiente tabla con una selección de extractos de otros 20 testimonios tomados del expediente 1.777/07:

\begin{tabular}{|l|l|}
\hline Testimonio EA & $\begin{array}{l}\text { "Cuando regresé de la de la guerra, pesaba } 52 \text { kilos, siendo } \\
\text { una persona de } 70 \text { kilos en época normal, fui internado en el } \\
\text { Hospital de Campo de Mayo" / Mientras estaba en el hospital } \\
\text { internado nos censuraban, no nos dejaban hablar con la } \\
\text { prensa, nos obligaban a que no habláramos con ningún civil, } \\
\text { que no contáramos la verdad" / "Hoy denuncia porque antes } \\
\text { habia mucho temor y por cuidar a mi familia no queríamos } \\
\text { hablar, aunque creo que ya hoy es demasiado tarde". }\end{array}$ \\
\hline Testimonio EB & $\begin{array}{l}\text { "Pregunta S.S. [Jueza Federal Lilian Herráez] si cuando } \\
\text { regresó a Argentina, algún funcionario le hizo firmar un acta o } \\
\text { le manifestó alguna circunstancia, responde que en la Escuela } \\
\text { Sargento Cabral, "un militar nos dijo que no podiamos hablar } \\
\text { durante siete años de los vimos, que a nuestras familias le } \\
\text { teniamos que decir que la pasamos muy bien, todo muy lindo en } \\
\text { Malvinas". }\end{array}$ \\
\hline Testimonio ED & $\begin{array}{l}\text { "Alli declaré y manifesté lo sucedido a WT, quien habia } \\
\text { resultado muerto a causa del accionar de Cabrera, pero no nón } \\
\text { recuerdo si firmé alguna declaración o algún papel, sólo } \\
\text { recuerdo que nos dijeron que no podiamos hablar con ningún }\end{array}$ \\
\hline
\end{tabular}




\begin{tabular}{|c|c|}
\hline & $\begin{array}{l}\text { periodista, ni que ande comentando todo lo que habia vivido en } \\
\text { la guerra" " "yo fui el último que declaré ante el Comandante } \\
\text { Cardenal, y él me dijo primero lo del consejo de guerra, y } \\
\text { cuando empecé a contar los de cabrera me dijo que cómo yo } \\
\text { iba a contar eso si todos los demás, anteriores no habian } \\
\text { contado nada de eso, yo le dije que confirmaba lo que estaba } \\
\text { diciendo que había sido Cabrera quien lo había matado. Ahí me } \\
\text { dice que yo no podía ir a juicio con un personal de cuadro (de } \\
\text { jerarquia) que tenía que ir al consejo de guerra y quedarme } \\
\text { cuatro o cinco años más en el regimiento. Yo le contesté que no } \\
\text { quería irme a juicio. Recuerdo que no se cuantos días, cuatro o } \\
\text { cinco días, vienen nuevamente los jefes con máquinas de } \\
\text { escribir, llevaron ya un papel llenado, escrito a mano y lo } \\
\text { pasaron a máquina, me llamaron y me leen la declaración, la } \\
\text { mía, y me dicen que tenía que firmar, yo le digo que no, que no } \\
\text { iba a firmar esa declaración, porque no había declarado así, } \\
\text { ahi estaba todo a favor de Cabrera" }\end{array}$ \\
\hline Testimonio EE & $\begin{array}{l}\text { "Pregunta S.S. [Jueza Federal Lilian Herráez] si en alguna } \\
\text { oportunidad pudo declarar sobre este hecho, responde que no } \\
\text { declaró nunca sobre este hecho, no los dejaban hablar, "nos } \\
\text { amenazaban con que si hablábamos sobre lo sucedido en } \\
\text { Malvinas (respecto a todo el conflicto y no sólo a este hecho } \\
\text { puntual) corríamos el riesgo de ser sometidos a consejo de } \\
\text { guerra y permanecer años encerrados". }\end{array}$ \\
\hline Testimonio EF & $\begin{array}{l}\text { "otro suceso que quiero declarar es que al volver nos llevaron } \\
\text { a la ESMA, alli nos hicieron firmar un pacto de silencio, era } \\
\text { una carpeta, nos decian que no debíamos comentar a nadie lo } \\
\text { que habia pasado en la guerra, que si comentábamos a algún } \\
\text { civil lo ocurrido ibamos a ser sometidos a un consejo de guerra. } \\
\text { Yo creo que muchos soldados terminaron suicidándose porque } \\
\text { no sabian a quien recurrir y donde contar lo sucedido, Yo } \\
\text { querría saber si puede ser recuperada esa carpeta y asi conocer } \\
\text { su contenido" }\end{array}$ \\
\hline Testimonio EG & $\begin{array}{l}\text { "Preguntado S.S. [Jueza Federal Lilian Herráez] qué sucedió } \\
\text { cuando volvieron de la guerra, responde "cuando volvimos al } \\
\text { BIM 5, ingresamos al polideportivo, se formaron boxes y se } \\
\text { sentaba un militar que comenzaba a interrogar sobre lo } \\
\text { sucedido en la guerra. Se trataba de un interrogatorio realizado } \\
\text { por el servicio de inteligencia. Primero nos decían que } \\
\text { tengamos cuidado con lo que declarábamos porque podíamos } \\
\text { ser sometidos a un consejo de guerra o algo así, por eso cuando } \\
\text { nos sentábamos a declarar no queríamos decir nada, sólo } \\
\text { queríamos irnos de allí y regresar con nuestras familias. Nos } \\
\text { hacían firmar un acta con nuestro testimonio y luego de una } \\
\text { semana nos dieron la baja y pudimos regresar" }\end{array}$ \\
\hline Testimonio de EH & $\begin{array}{l}\text { "antes de salir de baja, estaba el teniente lro. Mejías, nos } \\
\text { reunió a todos y nos dijo "bueno miren ustedes van a volver a } \\
\text { la vida civil, no tienen porqué comentar lo que pasó en } \\
\text { Malvinas, allá no hubo hambre, no hubo sufrimiento, no hubo } \\
\text { maltrato". "Hubo algunos Oficiales que se portaron así, yo no } \\
\text { estoy en contra de la institución, otros se portaron mejor, } \\
\text { tuvieron heroísmo y patriotismo". }\end{array}$ \\
\hline Testimonio de EI & $\begin{array}{l}\text { "en dos buques nos llevaron hacia Campo de Mayo. } \\
\text { Físicamente estaba destruido, no me podía calzar porque } \\
\text { padecía "pie de trinchera", ahi estuve poco tiempo, una } \\
\text { semana. Llegamos el } 13 \text { de junio y el } 20 \text { de junio partimos a } \\
\text { Mercedes. Me tuve que quedar ahí haciendo la conscripción de } \\
\text { dicho regimiento hasta el } 24 \text { de septiembre, cuando me dieron } \\
\text { la baja. Estuve internado dos dias en el hospital del regimiento, } \\
\text { por la desnutrición el problema en el pie. Luego de esos dos } \\
\text { días me dieron la licencia, hasta que llegó la baja el } 24 \text { de } \\
\text { septiembre, donde recién me entregaron el documento. } \\
\text { Pregunta S.S. [Jueza Federal Lilian Herráez] si antes de salir } \\
\text { de campo de mayo fue interrogado por el servicio de } \\
\text { inteligencia, responde "nos dijeron si queríamos declarar o } \\
\text { denunciar algo de lo que había pasado, pero como teníamos } \\
\text { miedo no declaré nada, creo que llegué a firmar un papel que } \\
\text { decía que estaba todo bien" }\end{array}$ \\
\hline
\end{tabular}




\begin{tabular}{|c|c|}
\hline Testimonio de EJ & $\begin{array}{l}\text { "Al llegar al regimiento de Mercedes, nos juntó a todos los } \\
\text { soldados el Teniente Coronel Piaggi y nos dijo "lo que teniamos } \\
\text { que decir o hablar lo teníamos que hacer por escrito ahi en ese } \\
\text { momento, en el pueblo no tenían que decir nada, nunca contarle, } \\
\text { a los civiles, porque ellos no tenían porqué enterarse" } \\
\text { lógicamente nadie firmo nada, por temor y porque no } \\
\text { confiábamos en sus palabras tampoco. Los que teníamos un } \\
\text { poco más de criterio sabíamos que estábamos dentro de una } \\
\text { dictadura militar y por lo tanto ninguna garantía de que esa } \\
\text { declaración llegue a buenas manos." }\end{array}$ \\
\hline Testimonio EK & $\begin{array}{l}\text { "yo estaba internado en Campo de Mayo y recuerdo que me } \\
\text { interrogaron si estaba conforme con el trato que habia recibido } \\
\text { por parte del personal del ejército, aunque no me dieron la } \\
\text { opción de contestar ni opinar y me hicieron firmar un acta de } \\
\text { que estaba todo de acuerdo. No sé quienes eran los que me } \\
\text { tomaron esa declaración" }\end{array}$ \\
\hline Testimonio de EL & $\begin{array}{l}\text { "fui en el Uganda, luego en el bahía paraíso, llegué a Santa } \\
\text { Cruz y luego a campo de mayo. Fui internado alli, me visitó } \\
\text { personal militar, quienes me hicieron firmar un acta donde yo } \\
\text { detallaba todos los hechos y me comprometieron a guardar } \\
\text { confidencialidad sobre lo sucedido. Nos ocultaban, cuando } \\
\text { llegamos al palomar, nos llevaban a todos escondidos en micros } \\
\text { todos pintados de negro los vidrios". }\end{array}$ \\
\hline Testimonio de EM & $\begin{array}{l}\text { "Y nosotros creo que estuvimos una semana más ahi y nos } \\
\text { dieron la baja si nos decían que no andemos comentando nada } \\
\text { de lo que habiamos pasado, agi adentro ellos creo que nos } \\
\text { dijeron cuando nos dieron la licencia ahí nos habían dicho que } \\
\text { no andemos hablando nada porque podíamos perder la baja } \\
\text { algo así creo que era" }\end{array}$ \\
\hline Testimonio de EN & $\begin{array}{l}\text { "Llegamos el } 21 \text { creo que fue, en Puerto Madryn, bajamos y } \\
\text { nos subieron a los colectivos. No nos dejaban tener contacto } \\
\text { con nadie, nos habian prohibido hablar, nos habian traido a la } \\
\text { base" }\end{array}$ \\
\hline Testimonio de EO & $\begin{array}{l}\text { "Cuando salió de la internación, a los pocos días le dieron la } \\
\text { baja. Pero cuando le van a dar la baja el Teniente Primero } \\
\text { Moran le avisa que tenía un sumario de guerra y que para } \\
\text { conseguir su baja tenía que declarar delante de él lo siguiente: } \\
\text { Que habia visto las conductas impropias del soldado FB en } \\
\text { combate. En una oportunidad, en el transcurso de la guerra, el } \\
\text { soldado FB se había escapado de la primera linea, se habia ido } \\
\text { al campo minado y al día siguiente había vuelto con un tractor. } \\
\text { El Teniente Primero Moran extorsionó al declarante, le exigió } \\
\text { que firmara una declaración en contra de Roche para otorgarle } \\
\text { la baja al declarante. El declarante afirma que fue extorsionado } \\
\text { para hacer esa declaración. Roche luego estuvo preso en } \\
\text { Campo de Mayo } 5 \text { años por ese hecho que fue probado por las } \\
\text { declaraciones de demás soldados, realizadas bajo extorsión de } \\
\text { sus superiores" }\end{array}$ \\
\hline Testimonio EP & $\begin{array}{l}\text { "desde alli, nuevamente en micros, a Campo de Mayo. UNa vez } \\
\text { arribados a Campo de Mayo, los hicieron bañar, les entregaron } \\
\text { un nuevo equipamiento, y los arengaron para que "olvidaran } \\
\text { todo lo vivido en Malvinas" }\end{array}$ \\
\hline Testimonio EQ & $\begin{array}{l}\text { "Al regreso de Malvinas, estuvo unos días en la Escuela de } \\
\text { Suboficiales Sargento Cabral, donde les dieron mucha comida. } \\
\text { Ya no podia comer porque tenía diarrea y un malestar } \\
\text { permanente. Le hicieron firmar una declaración jurada por la } \\
\text { cual se les permitia solamente hablar sobre la geografia de } \\
\text { Malvinas y de ningún otro aspecto. En una formación el } \\
\text { Teniente Primero César Augusto Buraschi dijo que si se } \\
\text { enteraban que los soldados manifestaban cuestiones de } \\
\text { Malvinas, iban a ser detenidos" }\end{array}$ \\
\hline Testimonio ER & $\begin{array}{l}\text { "El declarante deja constancia que el enemigo era interno, eran } \\
\text { sus superiores. Manifiesta que cuando volvió de la guerra, su } \\
\text { ropa habia sido robada del regimiento y tuvo que volver a su } \\
\text { casa con el uniforme. Agrega que antes de pasar por el }\end{array}$ \\
\hline
\end{tabular}




\begin{tabular}{|l|l|}
\hline & $\begin{array}{l}\text { regimiento, al regreso, estuvieron dos o tres dias en la Escuela } \\
\text { de Suboficiales Sargento Cabral, donde le hicieron firmar un } \\
\text { documento en el cual lo obligaban a comprometerse a no decir } \\
\text { nada sobre lo que ocurrió en el conflicto, bajo apercibimiento } \\
\text { de ser sancionado con el Código Militar" }\end{array}$ \\
\hline Testimonio ES & $\begin{array}{l}\text { "Aclaro, que cuando se me da la baja, personal militar y de } \\
\text { inteligencia nos hicieron firmar una planilla o documento } \\
\text { donde nos prohibieron todo tipo de comentario y/o referencia } \\
\text { y/o relato del conflicto, y los sucesos vividos durante el mismo } \\
\text { a periodistas y familiares" }\end{array}$ \\
\hline Testimonio ET & $\begin{array}{l}\text { "Aclaro, que estando en Campo de Mayo, personal militar de } \\
\text { inteligencia nos hicieron firmar una planilla o documento } \\
\text { donde nos prohibieron todo tipo de comentario y/o referencia } \\
\text { y/o relato del conflicto" }\end{array}$ \\
\hline Testimonio EU & $\begin{array}{l}\text { "antiguamente no podiamos hablar de esto } \text { [refiere a los hechos } \\
\text { de tortura], porque si hablábamos ellos nos hán pelota } \\
\text { [refiere a los militares], teniamos esa amenaza y hoy tengo esa } \\
\text { libertad de expresar lo que dice mi corazón" }\end{array}$ \\
\hline
\end{tabular}

\section{Nota de campo 7: “Cecimito”, un soldado estaqueado en la Corte Suprema}

Martes 23 de mayo de 2017. 10 de la mañana. Lanzamos la campaña "Justicia por Malvinas”, a 10 años de iniciada la causa. ¿Dónde? En las escalinatas de Talcahuano 550, sede de la Corte Suprema de Justicia de la Nación.

En otras oportunidades habíamos estado en ese lugar. En 2013 y en 2015 ya nos habíamos manifestado allí. La primera vez, para denunciar el retardo de justicia del recurso extraordinario federal, luego de que hubiera dictaminado el Procurador subrogante, González Warcalde. La segunda, en ocasión de solicitar una revocatoria y aclaratoria, luego de que conociéramos la resolución de la Corte del 19 de febrero de 2015. Aquella vez, tras aquella presentación, en mayo del mismo año, el Tribunal Supremo decidió aclarar los alcances de su resolución, siempre, por supuesto, manifestando en forma expresa que no es tradición de ese noble cuerpo el expedirse sobre decisiones previas. No sé. 1 a 0 . Fue tanto el revuelo que debieron hacerlo, aún cuando, claro está, no es tradición y blablabla...

Martes 23 de mayo de 2017. Una vez más ante la Corte. Ahora acompañados, como en otras oportunidades, por representantes de la Comisión Provincial por la Memoria (CPM), Taty Almeida en representación de Madres de Plaza de Mayo Línea Fundadora, representantes de H.I.J.O.S, del Centro de Militares para la Democracia Argentina (CEMIDA), de la CONADEP, Edgardo Esteban, entre otros. Además, contamos con la presencia de "Cecimito", el soldado estaqueado. 
Se trata de una representación de un soldado estaqueado que es utilizada para graficar las torturas que padecieron cientos de exsoldados conscriptos combatientes en Malvinas.

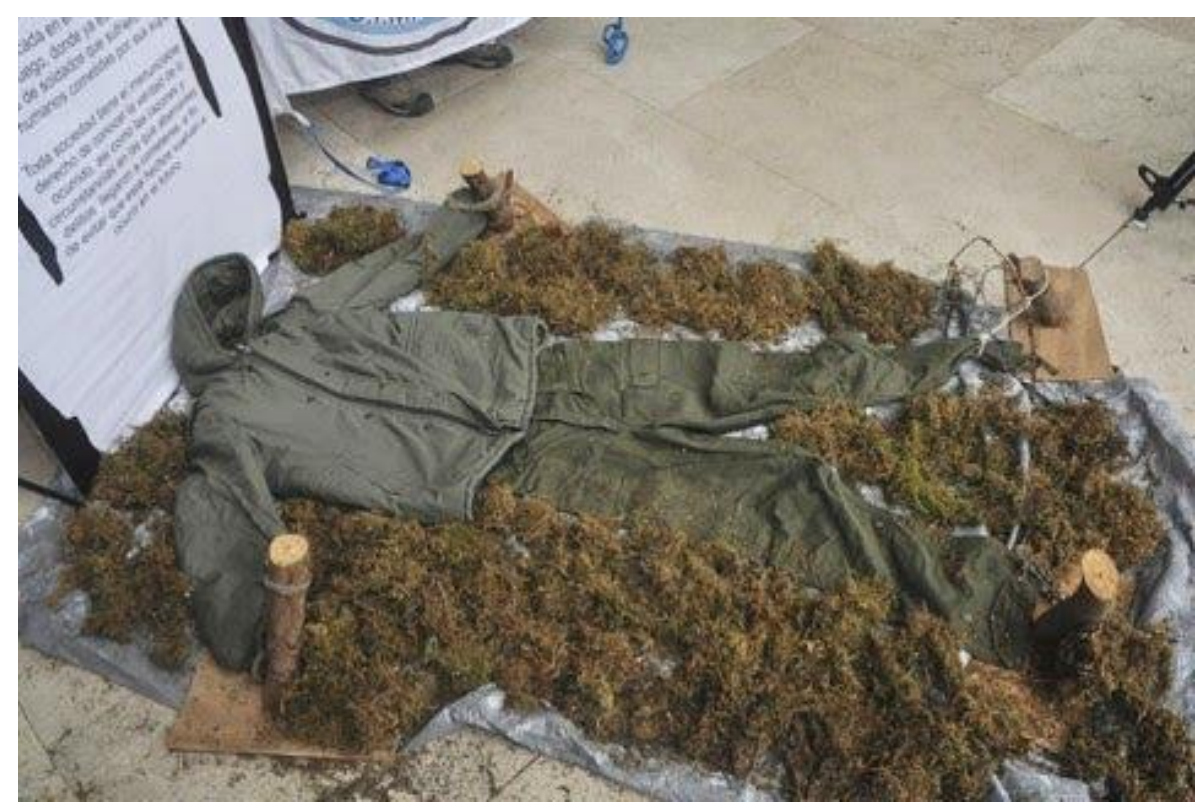

Como en aquellas oportunidades, montamos la intervención en las escalinatas de la Corte. Junto a Laurentina Alonso fuimos hasta la mesa de entrada, y presentamos un escrito en el que solicitamos se provea de recursos y personal al Juzgado Federal de Río Grande, a fin de poder abordar en forma específica una causa cuya magnitud así lo amerita (la 1.777/07). Si no recuerdo mal, nos contestaron dos o tres meses más tarde, diciendo, como es costumbre de las y los Supremos, que esa no era la vía para plantear ni, mucho menos, resolver, cuestiones tan sensibles. Es increíble cómo la solemnidad es utilizada como un escudo, un pararrayos frente a demandas populares. Las y los cortesanos no se embarran. No hablan. No dan explicaciones. No rinden cuentas. Hay, en el edificio, un halo medieval, resabios de lógicas dinásticas.

Valga esta digresión. En 2019 tuvimos que asistir a Talcahuano 550 junto a Laurentina por otra presentación relacionada con el CECIM. Era una medida cautelar autónoma contra un Decreto del Poder Ejecutivo Nacional, de Mauricio Macri, que habilitaba los vuelos San Pablo - Malvinas. Por cuestiones geopolíticas y, básicamente, amparándonos en los efectos del estoppel (o doctrina de los actos propios -algo así como que ningún Estado puede alegar su propia torpeza y retrotraer situaciones fácticas y/o jurídicas surgidas de su propia voluntad soberana, cuando ellas benefician a terceros, es 
decir, otros Estados-) decidimos impedir que se produjera el primer vuelo pautado, con sumo cinismo, para el 20 de noviembre de 2019. Sí, para el Día de la Soberanía Nacional. En dicha oportunidad, mientras recorríamos los pasillos intentando dar con una oficina, se me ocurrió tomar una fotografía con mi teléfono celular.

En menos de cinco segundos, tenía a mis espaldas a una persona de traje expresándome que, por orden expresa de los Ministros, no se podía tomar fotografías. Aclaro, para lectores o lectoras distraídos, que no estaba frente a documentos clasificados de Estado. Simplemente quise tomar una fotografía de un vitral. Se ve que a las y los Ministros les molesta que la "vulgata" sepa que al interior del acorazado castillo hay vitrales. En fin...

Vuelvo al 23 de mayo de 2017. Cuando regresamos de realizar la presentación con Laurentina, la escena estaba montada. Los/as distintos/as participantes se habían colocado en las escalinatas, y llevaban en sus manos unos carteles que expresan: "Justicia por Malvinas. Memoria, Verdad, Justicia y Soberanía”. A los pies de quienes se encontraban en los escalones más cercanos a la vereda, estaba "Cecimito", el soldado estaqueado. Con un megáfono, las autoridades del CECIM y otros/as participantes, como Taty Almeida, se dirigieron a los medios de comunicación. Al terminar la intervención, dimos algunas entrevistas. Luego regresamos a La Plata. Pasaron más de 2 años para que se tomaran las primeras 4 declaraciones indagatorias a los denunciados (diciembre de 2019).

\section{9.- Las primeras 4 indagatorias. Los primeros 4 procesamientos. El reconocimiento de las tecnologías de la impunidad por parte del Estado}

Una de las características de la presente investigación es su realización en caliente. Las experiencias que se relevaron, los testimonios, la desclasificación de los archivos, el curso judicial, van configurando una trama viva.

De esta forma, mientras seleccionaba piezas para dotar de sustento a la hipótesis que guía el trabajo, conocí el fallo judicial por el que la Jueza Federal de Río Grande, Tierra del Fuego, Antártida e Islas del Atlántico Sur, decidió procesar a 4 militares acusados de haber torturado soldados conscriptos durante la guerra de Malvinas (el mismo salió a la luz en febrero de 2020).

Dichos militares fueron, previamente, indagados en diciembre de 2019. En aquella oportunidad, como abogado de la querella del Centro de Ex Combatientes Islas Malvinas 
La Plata, viajé para presenciar el mentado acontecimiento. Si bien no pudimos participar de las audiencias, por las limitaciones que la normativa procesal estipula a los querellantes en dicha etapa del proceso, pudimos presenciar los sucesos.

Los militares Miguel Ángel Garde, Belisario Gustavo Affranchino Rumi, Eduardo Luis Gassino, y Gustavo Adolfo Calderini se convirtieron en los 4 primeros militares procesados por los delitos de imposición de tormentos, hechos calificados como delitos de lesa humanidad. También aparecen en el fallo otros delitos, en concurso ideal, como amenazas, amenazas agravadas, y abuso de armas.

Uno de los puntos salientes, en relación con la autoría, es que la Jueza Federal de Río Grande comprendió que, amén de la responsabilidad por la imposición de tormentos, existió también autoría mediata, dada principalmente por las posiciones de sujeto dentro de la estructura jerárquica:

De esta manera, se crearía una categoría que puede definirse como autores mediatos intermedios, que solo resulta posible en estructuras verticales y jerárquica.

La proliferación, dentro de un mismo Regimiento, del mismo tipo de sanciones aplicadas ante la supuesta comisión de una misma clase de faltas disciplinarias por parte de los soldados, permiten suponer la existencia de un plan o acuerdo respecto de la manera en que se llevaría adelante la administración de dichos castigos durante el tiempo que durara el conflicto bélico.

Esta circunstancia se evidencia en los relatos de las víctimas y testigos, quienes describen prácticas inhumanas para sancionar a los soldados acusados de robar comida, consistentes en los estaqueos, enterramientos y sometimiento al frío y al hambre en diversas modalidades, así como una indistinta participación en la aplicación de los mismos por parte de los oficiales y suboficiales de las distintas unidades.

La imposición de tormentos por parte de oficiales y suboficiales incluso a soldados que no se encontraban operativamente bajo a su mando directo, es un claro indicio de la naturalización e internalización de este particular sistema de castigos por parte de todos los miembros de la organización militar que se encontraba apostada en el territorio de Malvinas.

Es en orden a ello que, tomando en consideración la ubicación de los imputados dentro del organigrama del Regimiento de Infantería 
$N^{o} 5$, se les ha atribuido esta particular modalidad de autoría, vinculada a sus posibilidades de conocer, dominar, ejecutar y/o hacer cesar las conductas que son objeto de investigación en las presentes actuaciones (Juzgado Federal de Río Grande, 2020: 63)

Si bien esta tesis se centra, en forma específica, en el accionar estatal desplegado una vez finalizada la guerra (14 de junio de 1982), es importante remarcar que la comisión de los hechos que se pretendieron silenciar, eran en sí mismos graves violaciones a los derechos humanos, caracterización que sitúa el énfasis en la calidad de agentes del Estado de los autores penalmente responsables, y en cómo la estructura orgánica facilitó la comisión de los mismos.

En lo que atañe al objeto de la investigación, la Magistrada ponderó la supresión de garantías que imperaba, y que profundizó el padecimiento de las víctimas, quienes se vieron privadas de resortes/mecanismos para poder denunciar los hechos. Al respecto, sostuvo:

Al respecto, si bien alguien podría considerar que los hechos narrados por las victimas en los presentes actuados, en principio, no darían cuenta de un plan sistemático como el que se desarrollaba por esos momentos en nuestro país, no puede negarse que los imputados actuaron en conocimiento y bajo el amparo de un sistema que había suprimido las garantías de los ciudadanos en general y que impedia toda posibilidad de reclamar contra las acciones ilegitimas de los miembros de las Fuerzas Armadas.

Manifiesto de esto es la documentación de las operaciones de inteligencia en las cuales consta el instructivo relacionado a la directiva del Comandante en Jefe del Ejército $N^{\circ} 316 / 82$ sobre medidas de seguridad de contrainteligencia.

Mediante dicho instructivo se brindaron directivas de restringir toda la información que afectara el prestigio de las Fuerzas Armadas, tales como las vinculadas a personal que se hubiera provocado lesiones de forma voluntaria, falencias en el apoyo logístico, actitud del personal de cuadros, etc., así como la solicitud de limitación de las declaraciones de soldados y suboficiales en relación a las condiciones en las que se desarrollaron las Operaciones que pudieran dañar la imagen de la institución militar. (Juzgado Federal de Río Grande, 2020: 23) 
Como puede apreciarse, el Poder Judicial también ha situado la lupa sobre la vertebración de lo que aquí he llamado tecnologías del ocultamiento (o tecnologías de impunidad).

\subsection{0.- Artículos periodísticos y amedrentamiento. La urdimbre de la impunidad}

Parte del montaje de las tecnologías de la impunidad tuvo que ver con la instauración de un discurso. Como hemos visto, el diseño de mecanismos de acción psicológica e inteligencia, incluyó directrices para con las líneas editoriales de los medios de comunicación.

En los últimos años, esos discursos se cristalizaron en artículos publicados en medios de comunicación de relevancia (por su alcance en términos de índices de consumo), en los que se busca desacreditar los avances producidos en la causa judicial. Principalmente, se afincan en datos inexistentes, forzados en términos de lógica proposicional, o bien en falacias ad hominem, construidas en base a ataques directos sobre quienes llevan adelante la querella.

Aquí se puntualizan algunas editoriales, una de La Nación, del 30 de junio de 2018; una misiva dirigida al Centro de Ex Combatientes Islas Malvinas La Plata el 10 de julio de 2018, firmada por Julio Saguier, Presidente de S.A. La Nación, en respuesta a una solicitud de derecho a réplica efectuada por el organismo querellante; otra editorial publicada en Infobae, el 25 de julio de 2018; una editorial de La Nación, de fecha 23 de diciembre de 2018; una nota de opinión en Perfil, firmada por José D’Angelo, el 5 de julio de 2019 (en réplica a una nota firmada por mí unos días antes, y sobre la que ejercí derecho a réplica en una nota posterior); y; por último, una editorial de La Nación, del 12 de marzo de 2020.

La primera, publicada en La Nación con el título "Malvinas: absurda persecución" (La Nación, 2018), expresa:

El teniente primero (R.) Taranto, junto con otros oficiales y

suboficiales, han sido destinatarios de una seguidilla

ininterrumpida e interminable de demandas dirigidas a demostrar 
la supuesta comisión de delitos de lesa humanidad durante la Guerra del Atlántico Sur, de 1982. Los responsables de tales persecuciones han sido identificados. Sus móviles tendrían connotaciones no solo económicas, sino también ideológicas y políticas.

Los perversos manejos en torno de las acusaciones descriptas tienen muchas similitudes con los episodios ocurridos alrededor del caso Maldonado.

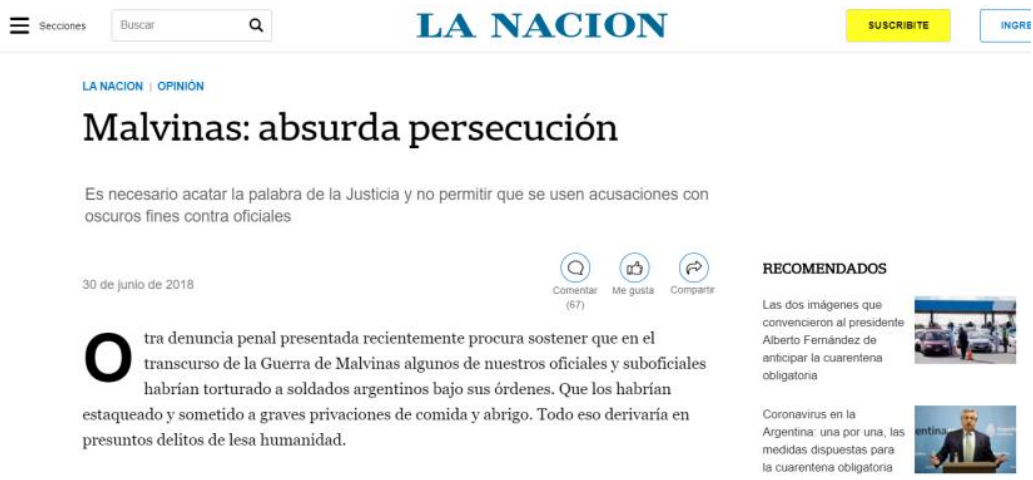

Frente a la editorial mencionada, el Centro de Ex Combatientes Islas Malvinas La Plata solicitó derecho a réplica. El mismo fue negado por el entonces Presidente de S.A. La Nación, Julio Saguier, en una misiva dirigida al organismo querellante en fecha 10 de julio de 2018. La misma nunca fue publicada, por lo que constituye una pieza documental inédita.

La afirmación de que los ex soldados conscriptos sostienen el llamado proceso de "Memoria, Verdad y Justicia" desde hace 36 años, quedan desmentidas al verificar que las primeras denuncias sobre el tema datan del año 2007, 25 años después de la GIM, 24 años después de la restauración democrática y que sólo el CECIM se ha presentado como querellante en las causas citadas en nuestra editorial.

Respecto de la existencia de un cuidadoso plan de inteligencias militar orientado a DLH en la GM, no hemos encontrado pruebas que acrediten tal planificación, por lo que los instamos a que nos las aporten. 
Negamos rotundamente que nuestra editorial constituya un aporte a la impunidad en materia de DLH. Si pretende en cambio contribuir para terminar con la impunidad con la que algunas organizaciones de DDHH actúan desde hace quince años en la Argentina.

La referencia a la similitud con escandalosos casos recientes como el de Santiago Maldonado no es más que una obviedad: el armado de un caso a la postre fracasado.

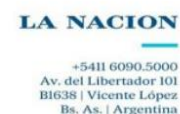

Buenos Aires, 10 de julio de 2018

Señores

Centro de Ex Combatientes Islas Malvinas -La Plata

At.: Sres. Hugo Robert y Ernesto Alonso

PRESENTE

De nuestra mayor consideración:

Nos dirigimos a Ud. en respuesta a su correo del 2 de julio pasado referido a nuestro editorial "Malvinas, absurda persecución" de fecha 30 de junio.

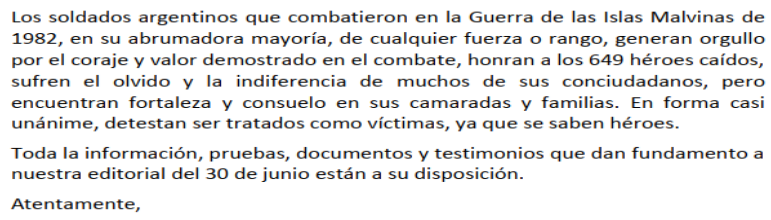

Islas Malvinas de sufren el olvido y la indiferencia de muchos de sus conciudadanos, pero

Atentamente,

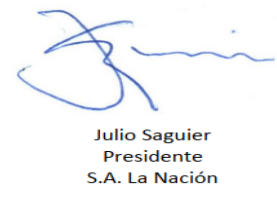

Otra de las editoriales a las que se hace referencia, fue publicada en Infobae, se titula "Los caranchos de nuestros muertos y heridos de Malvinas", y está firmada por Horacio Sánchez Mariño (2018). En ella, el autor afirma: 
En los últimos años asistimos al decadente espectáculo de los caranchos trabajando sobre la carne de nuestros muertos y heridos de la guerra de las Malvinas.

Todo se inició con la persecución ideológica de las fuerzas armadas utilizando los derechos humanos y los delitos de lesa humanidad en forma indiscriminada. La aplicación de estos conceptos sublimes, nacidos para defender la dignidad humana por el solo hecho de nacer, se aplicó en Argentina de manera tergiversada, al punto de generar una conspiración que traicionó a los combatientes de Malvinas y puso en cuestión una gesta nacional. La traición es aviesa porque hiere profundamente el honor y el prestigio de los denunciados.

Y continúa:

Desde el año 2007, las organizaciones de derechos humanos trabajan para convertir una gesta heroica y cargada de sufrimientos para todos los protagonistas en un relato infame sobre torturas a los soldados. La Secretaría de Derechos Humanos de la provincia de Corrientes, conjuntamente con el CECIM de la Plata, una organización que gozó de privilegios y prebendas durante el kirchnerismo, reclutó a soldados veteranos para que denunciaran a los oficiales y suboficiales por provocar hambre y torturas. A cambio, les ofrecieron recompensas económicas.

\section{infolbae}

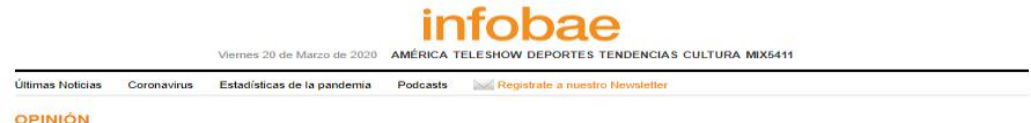

\section{Los caranchos de nuestros muertos y heridos de} Malvinas

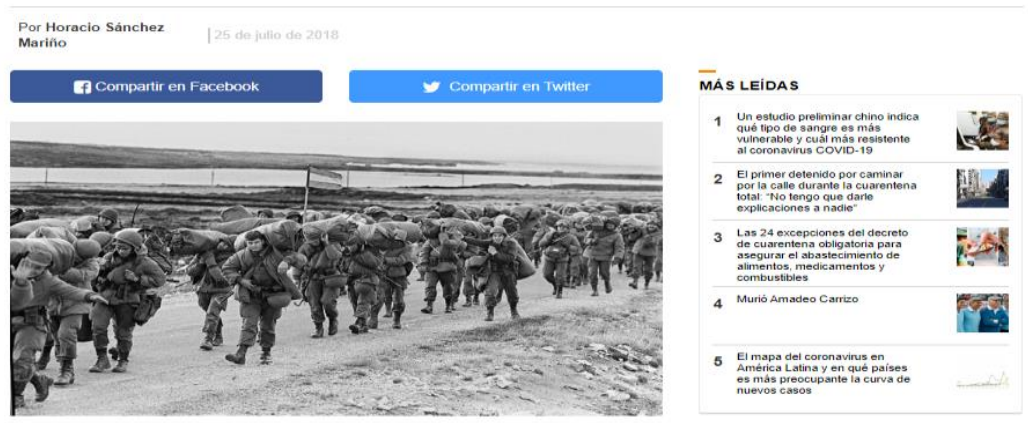


En diciembre del mismo año (2018), se publicó una editorial sin firma en La Nación, titulada "Malvinas: otro uso espurio de los derechos humanos" (La Nación, 2018b):

Más allá del episodio de esta persistente denuncia que la Justicia seguramente desestimará, no es razonable que las acciones de la guerra sean juzgadas por la Justicia Federal con aplicación del Código Penal y no por una Justicia Militar con su propio código. Una fuerte reacción con mucha carga emocional antimilitar que pervive actualmente y que deberíamos revisar a la luz de gruesos errores como los que comentamos, suprimió estos instrumentos y hoy cualquier miembro de las Fuerzas Armadas está injustamente expuesto a que su intervención en una acción militar en cumplimiento de una orden, pueda ser equiparada a un asesinato. Si la Justicia no es ecuánime, deja de ser Justicia.

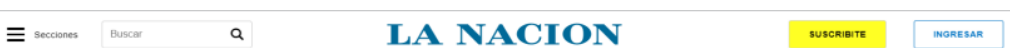

Malvinas: otro uso espurio de los derechos humanos

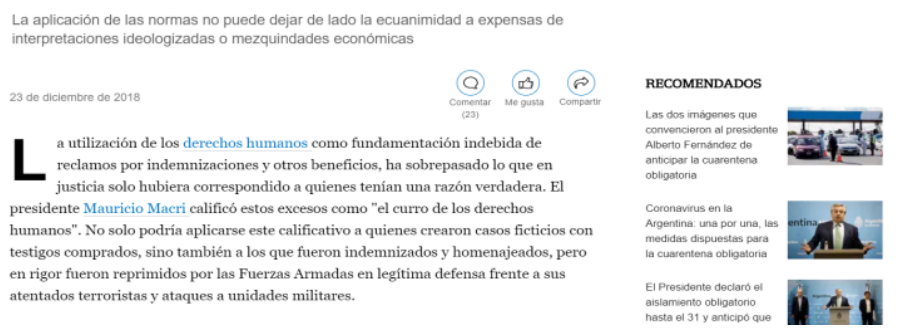

Asimismo, el 5 de julio de 2019, se publicó en Perfil un artículo firmado por José D'Angelo, cuyo título es "Una farsa para convertir a las Islas Malvinas en sucursal del negocio con los Derechos Humanos” (D’Angelo, 2019), en que responde a una nota de opinión firmada por mí, titulada “Torturas en Malvinas: en favor de la Justicia o cómplice de los hechos"38 (Guerrero Iraola, 2019).

${ }^{38}$ Frente a esa nota ejercí el derecho a réplica por medio del artículo "Malvinas: el único negocio para ciertos sectores es la impunidad" (Guerrero Iraola, 2019a) en el que me aboco a rebatir uno a uno los falaces argumentos de D'Angelo. 
En un artículo publicado en este medio, el Dr.Jerónimo Guerrero Iraola relata supuestas torturas y otros crímenes durante la Guerra del Atlántico Sur de 1982. El abogado del Centro de Ex Combatientes Islas Malvinas (CECIM) de La Plata no ahorra mentiras y ataques a personas e instituciones que llegan al sarcasmo cuando se refiere a héroes argentinos caídos en la Isla Gran Malvina, en diversas acciones bélicas localizadas alrededor de la posición argentina del Regimiento de Infantería 5 (RI 5)en Puerto Yapeyú (Puerto Howard).

En una cosa tiene razón el Dr. Jerónimo Guerrero Iraola: hemos llegado a un punto de inflexión, pero no para dirimir un nuevo encuadramiento legal al amparo del Derecho Humanitario Internacional, sino para terminar de una buena vez por todas con este intento de lucrar con esta farsa, intentando vanamente mancillar a nuestros héroes de Malvinas.

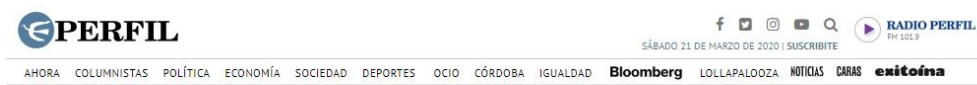

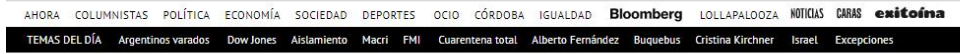

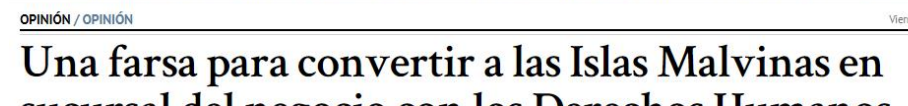
sucursal del negocio con los Derechos Humanos

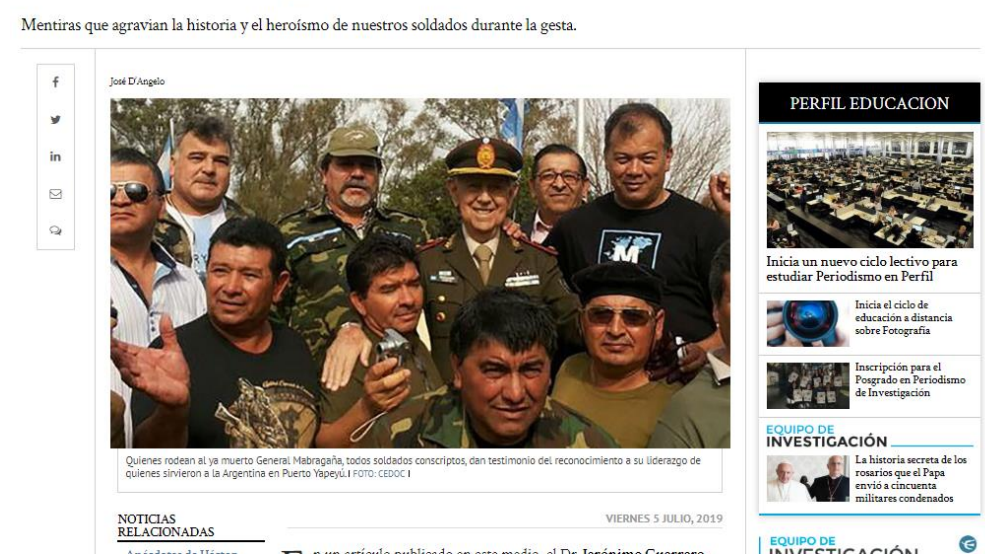

Por último, el 12 de marzo de 2020, luego de que se conocieran los primeros 4 procesamientos a militares acusados de haber torturado soldados durante la guerra de Malvinas, La Nación publicó una editorial titulada "La Guerra de las Malvinas y los derechos humanos" (La Nación, 2020), cuya bajada habla de La apertura de causas contra las Fuerzas Armadas por la comisión de delitos inexistentes es una aberración con fines exclusivamente económicos. 
Entre ellos, quien se destaca por inventar hechos, argumentos y víctimas para luego acechar a sus supuestos victimarios, es el exsoldado Ernesto Alonso, hoy secretario de Derechos Humanos del Centro de Excombatientes de las Islas Malvinas (Cecim), de La Plata. Su actitud queda reflejada en las siguientes palabras: "Para abordar la cuestión Malvinas desde la educación (...) es importante, para la etapa que se viene, deconstruir los estereotipos del 'héroe' fundados en la lógica del patriarcado, dentro de un pacto extremadamente machista". Tanto Alonso como el Cecim han recibido el repudio unánime de miles de excamaradas y de más de 200 centros de veteranos de guerra de Malvinas.

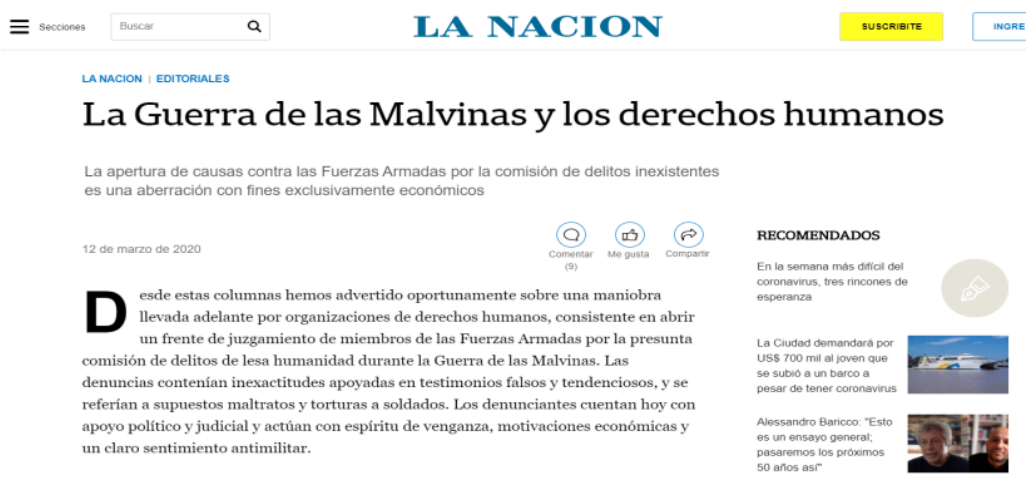

Este tipo de cuestiones han sido constantes desde la finalización de la guerra de Malvinas. Si se anudan con el resto de las disposiciones y lógicas que emplearon las fuerzas armadas, se puede configurar el modo en que fueron vertebradas las tecnologías de la impunidad (o tecnologías de ocultamiento).

\section{Nota de campo 8: Audiencia en Comodoro, el episodio del aeropuerto con Ribas}

Taranto II. Jorge Eduardo Taranto fue la persona denunciada que en, 2015, se vio beneficiada individualmente por la resolución de la Corte Suprema de Justicia de la Nación (2015b). Es la persona por la que, en parte, sostenemos la Petición P 460-15 ante la Comisión Interamericana de Derechos Humanos. Sin embargo, fue denunciado por nuevos casos en la Provincia de Chaco. El eterno retorno y alguna omnipresencia del 
valor justicia nos abrieron una puerta. Hoy Taranto, que creyó estar eximido de dar explicaciones al Poder Judicial por las prácticas de tortura de las que se lo acusa, se encuentra atravesando el proceso penal. Sucede que no hay non bis in idem. No hay identidad de víctimas y, por tanto, el castillo de consolidación de impunidad que había logrado edificar, se desplomó, se desvaneció en el aire.

Taranto ha comandado la ofensiva contra la causa. Trabaja en Infobae, y es muy cercano al CEO del medio (algunos dicen, su "mano derecha"). Administra la Página de Facebook "Malvinas la Verdadera Historia", desde donde dispara críticas al CECIM La Plata y, particularmente, a Ernesto Alonso y a Pablo Vassel. También, cada tanto, ataca deliberadamente al Fiscal de la causa, Marcelo Rapoport.

Una de las cuestiones que más llamó nuestra atención, fue que, la resolución de la Corte que lo benefició, se conoció el 19 de febrero de 2015. Pocos días después, en la apertura del año judicial, pudimos ver una foto del entonces Presidente de la Corte, Ricardo Lorenzetti junto a la Directora de Comunicación Pública, María Bourdin, y el CEO de Infobae, Daniel Hadad. Él es Taranto.
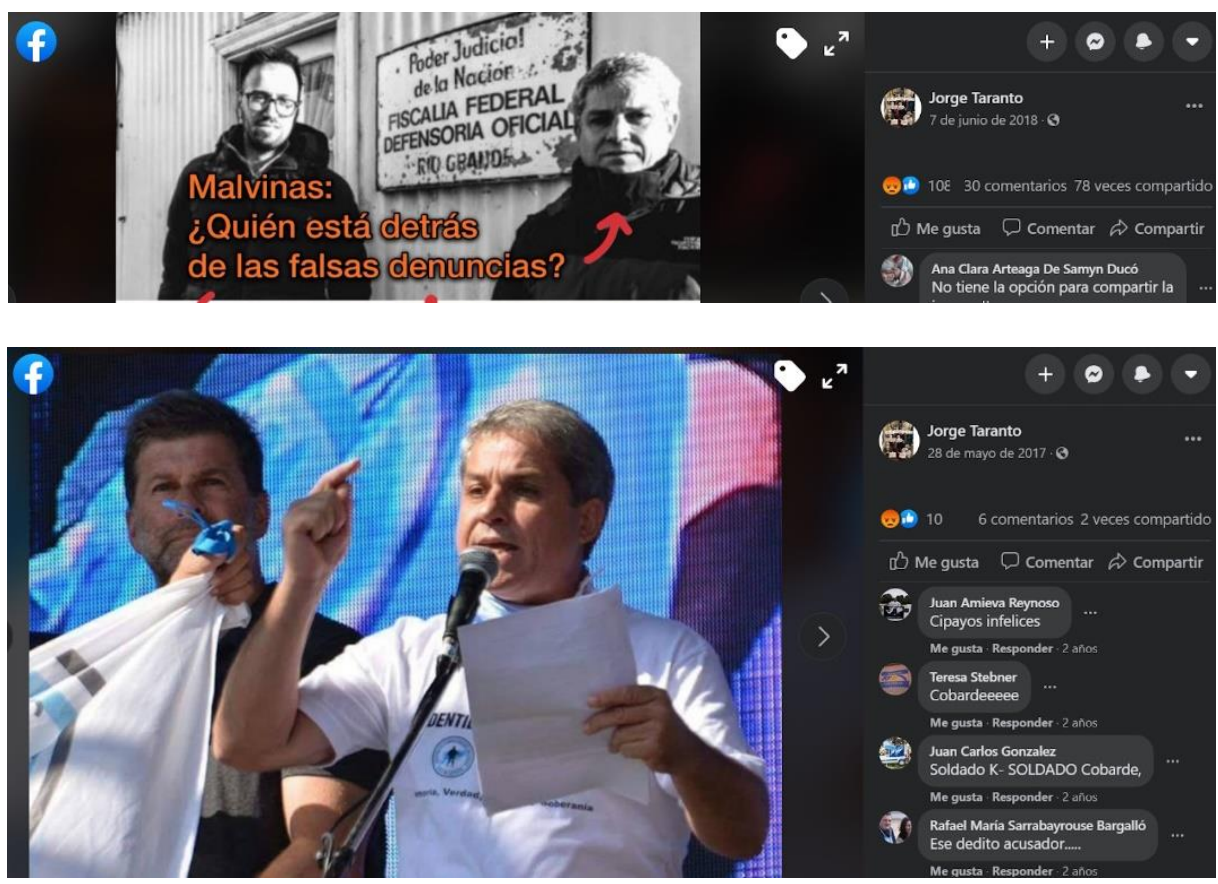

Vuelvo. Taranto II habla de este retorno de Jorge Taranto a la causa. Ahora denunciado por otros hechos de tortura. La novedad es que, en esta oportunidad, para la instancia recursiva optó por un abogado particular (en Taranto I, había sido defendido por 
la defensa oficial). Su patrocinante es, ahora, Roberto Ribas. En estas lógicas de senderos que se bifurcan, es interesante consignar, en estos apuntes de campo, que Ribas es también el abogado patrocinante de Carlos Stornelli en la causa por espionaje que tramita ante el Juzgado Federal de Dolores, cuyo Magistrado es Alejo Ramos Padilla, y quien fue abogado del CECIM hasta meses antes de que yo ingresara al organismo. A su vez, Stornelli estuvo presente el 29 de 2019 en el acto por el Día del Ejército, en el que Claudio Pasqualini, Jefe del Ejército, se refirió a la causa por torturas en Malvinas como "ciertas imputaciones pretenden echar sombra sobre el heroísmo y coraje de nuestros combatientes". No creo en las casualidades. Si en las paradojas de estas temporalidades que se superponen, se yuxtaponen, se entrecruzan.

Taranto, en Taranto II, primero con la defensa oficial, y luego junto a su abogado Ribas, presentaron un planteo judicial. Excepción de falta de acción y prescripción. Asimismo, presentó un planteo impugnando la calidad de querellantes de la Comisión Provincial por la Memoria de la Provincia de Buenos Aires (CPM), de la Secretaría de Derechos Humanos de la Provincia de Buenos Aires, y del CECIM. El mismo fue rechazado por Calvete, Juez Federal de Ushuaia que, durante varios años, subrogó el Juzgado de Río Grande. La causa llegó a la Cámara de Apelaciones de Comodoro Rivadavia. E1 22 de agosto se llevó adelante la audiencia. Participamos, Micaela Guevara y María Agostina Ferraro por la Secretaría de Derechos Humanos de la Provincia de Buenos Aires; Roberto Cipriano García por la CPM, Ernesto Alonso (Beto) y yo. En la misma estuvieron presentes la camarista Hebe Corchuelo de Huberman, y los camaristas Javier Leal de Ibarra y Aldo Suárez.

La audiencia quedó marcada, por una cuestión central. No supimos, hasta celebrada la audiencia, si iba o no a estar presente Jorge Taranto. Había, en la previa, cierta expectativa y adrenalina. Taranto no estuvo. Sí Ribas. Tuve con él, algunos cruces acalorados. Me trató de "abogadito" luego de que le manifestara que carecía de honestidad intelectual. A su vez, esbocé alguna chicana al aducir que hablaba mucho de prescripción, pero no había negado las torturas. Eso lo hizo enojar.

La audiencia terminó. Con Beto y Roberto saludamos a los/a camaristas/a. No a Ribas. Por definición y convicciones no saludamos a los abogados (hasta ahora todos varones) de los militares denunciados. Las abogadas de la Secretaría, Micaela y Agostina, salieron rápido hacia el aeropuerto pues su vuelo salía a las 14:30 (serían las 12:50). Con Roberto y Beto fuimos a comer. Almorzamos una parrillada. Nuestro vuelo salía 16:30. Tras el almuerzo, tomamos un taxi hasta el aeropuerto. Estábamos cansados. Habíamos 
viajado toda la noche (el vuelo con el que arribamos a Comodoro había salido a las $5 \mathrm{am}$, por lo que a las 3 pasó Roberto por mí en un remisse, y de allí buscamos 3:30 a Beto). Llegamos al aeropuerto de Comodoro. Realizamos el check in. La sala de embarque es una planta relativamente pequeña. Se puede ver de un extremo a otro. Allí estaba, Ribas, sentado. Su mirada era penetrante. Estuvimos con esa tensión sobrevolando el ambiente la hora previa a tomar el vuelo.

Volvimos en el mismo avión. Al embarcar, lo perdimos. No volvimos a verlo.

\subsection{1.- Discurso del Jefe del Estado Mayor del Ejército en el marco de la conmemoración del Día del Ejército 2019}

El 29 de mayo de 2019, "Día del Ejército" (oportunidad en que se celebró el 209 aniversario de la creación de la fuerza), el Jefe del Estado Mayor del Ejército, Claudio Pasqualini expresó (Infobae, 2019):

\footnotetext{
A 37 años de la gesta de Malvinas, rendimos un merecido homenaje a nuestros veteranos de guerra: oficiales, suboficiales y soldados. Combatieron todos juntos con gran valor y arrojo compartiendo privaciones y sacrificios. Actualmente, ciertas imputaciones pretenden echar sombra sobre el heroismo y coraje de nuestros combatientes. Todos dieron lo mejor de sí por la defensa de nuestras Islas. Lucharon y defendieron cada posición con bravura. En la Isla Gran Malvina resistieron bajo condiciones de aislamiento extremo. Vaya entonces a nuestros veteranos de Guerra de Malvinas el especial reconocimiento de todo el Ejército.
}

Dos días después del discurso la Jueza decidió suspender las 18 indagatorias que habían sido llamadas inicialmente para ser sustanciadas entre el 27 de junio y el 4 de julio de 2019. En la resolución, la Jueza Federal de Río Grande, Tierra del Fuego, Antártida e Islas del Atlántico Sur adujo limitaciones de personal y falencias edilicias.

Si bien, como se expresa en acápites previos, las indagatorias comenzaron a tener lugar en diciembre de 2019, la mencionada suspensión puso en alerta a las querellas, dado 
que entendieron que la proximidad de la medida con las declaraciones de Pasqualini eran sintomáticas.

Por su parte, en una audiencia celebrada el 31 de mayo en Río Grande, de la que participé como abogado del Centro de Ex Combatientes Islas Malvinas La Plata, le expresamos el temor que nos generaban las afirmaciones del Jefe del Ejército, sobre todo en lo concerniente a la guarda que éste ejercía sobre la documentación desclasificada, que resulta ser prueba indispensable para acreditar los hechos investigados.

\section{Nota de campo 9: Audiencia en Río Grande con la Jueza Mariel Borrutto}

31 de mayo de 2019. Río Grande, Tierra del Fuego, Antártida e Islas del Atlántico Sur. El 24 de mayo de ese año la Jueza, recientemente asumida, había decidido suspender las dieciocho indagatorias a militares, que se iban a dar entre el 27 de junio y el 4 de julio.

El viaje estaba previsto desde antes de la suspensión. Habíamos solicitado una audiencia, como querellantes, para informarnos sobre aspectos relativos a las indagatorias. La suspensión, aquel viernes 24 de mayo había sido un balde de agua fría. La causa llevaba, en ese entonces, 12 años de trámite. Recuerdo que, cuando me notificó (viernes 24 de mayo), estaba por ingresar a la escuela de mi hijo mayor, Simón, para presenciar el acto con motivo del 25 de mayo. Inmediatamente, tras leer la cédula, llamé al Secretario del Juzgado. Discutimos acaloradamente. Todos los planes habían cambiado.

A Río Grande viajamos Ernesto Alonso (Beto) y yo por el CECIM, Yamila Zabala Rodríguez por la Comisión Provincial por la Memoria de la Provincia de Buenos Aires, y María Agostina Ferraro, como abogada de la Secretaría de Derechos Humanos de la Provincia de Buenos Aires. Tomamos el vuelo de la madrugada. Sale de aeroparque alrededor de las 4. La mayoría de los viajes, desde 2011, los hacemos en ese horario. Ello implica para mí, dormir en un sillón, esperando que a las 2 am pase Beto a buscarme.

Llegamos alrededor de las 7 a Tierra del Fuego. Desayunamos en el hotel, dejamos el equipaje, y nos dirigimos al Juzgado. Al llegar, en la puerta había una manifestación de la UOM en apoyo a las querellas. El tema, en todo Tierra del Fuego, suele despertar apoyo local, y un revuelo mediático importante. Había periodistas de varias radios y de prensa gráfica (El Sureño y El Diario del Fin del Mundo suelen dedicar sus tapas a estos 
episodios). Ingresamos al Juzgado. La Oficina de Borruto es pequeña. A la comitiva se sumó Pedro Morales, exsoldado del Batallón de Infantería Marina 5 (BIM5).

La audiencia fue compleja. Acalorada. El 29 de mayo, apenas dos días antes, el Jefe del Ejército se había referido a las denuncias como "ciertas imputaciones pretenden echar sombra sobre el heroísmo y coraje de nuestros combatientes". Le manifesté dos cuestiones. La primera, es que con la decisión de suspender las indagatorias estaba vulnerando derechos fundamentales, y estaba revictimizando a los denunciantes. En segundo lugar, le expresé la preocupación ante las consideraciones de Pasqualini. A esto último respondió que "no se iba a meter en política". Allí la tensión escaló. Le respondí que no se trataba de consideraciones políticas, que el Jefe del Ejército, que se manifestaba en ese sentido, ejercía la superintendencia en la administración de los archivos que, aún hoy, son prueba fundamental en la causa a su cargo, y que por tanto, queríamos que se labrase un acta, en la que dejar asentado que, ante destrucciones, faltantes o menoscabo a dicho fondo documental, ella se haría responsable.

Yamila Zabala Rodríguez también le espetó cuestiones relacionadas con el derecho de las víctimas a que se investigue, y cómo deben actuar los/as Magistrados/as frente a casos como estos. Hablo de debida diligencia. Pedro Morales, a su turno, y con el sentimiento de impotencia impreso en sus palabras, le manifestó que querían justicia, que era una falta de respeto que no se avanzara, a 12 años (en 2019) de comenzada, con las declaraciones de los militares. Relató experiencias personales.

Borruto, quien para el final de la audiencia se encontraba con su Secretario, Juan Vicente, se excusó alegando falta de recursos, una gran cantidad de amparos por salud y que se había encontrado con una situación compleja para la gestión judicial. Allí, interrumpí y busqué en Google la exposición ante la Comisión de Acuerdos del Senado de la Nación de unos meses antes, previo a su designación. Aquí hay que aclarar que, al momento de la suspensión de las indagatorias, Borruto había sido designada unas semanas antes. Sin embargo, se había desempeñado desde los inicios, en distintos roles. Esa trayectoria al interior del Juzgado, fue uno de los puntos que esgrimió ante las y los Senadores para defender su candidatura. Su alocución la había visto en Internet. Saqué a relucir el material. Le manifesté que una persona que argumentaba conocer al dedillo el ámbito, no podía bajo ningún pretexto afirmar que se había encontrado con una situación compleja para la gestión judicial. Además, en 2007, momentos en que la Jueza era Lilian Herráez, ella se desempeñaba como Secretaria del Juzgado, y tomó en persona algunas 
denuncias. Ello se lo refrescamos rebatiendo la idea de "sorpresa" frente a la envergadura de la causa que intentó esbozar.

Finalmente, Beto le manifestó el punto de vista del CECIM. Le expresó que queríamos respuestas y que necesitábamos que se fijaran a la mayor brevedad posible las indagatorias.

Yo, para ese entonces, salí del despacho de Borruto, y me dirigí al de Vicente. Él redactó el acta. Pedí que consignara expresamente que consignara que se estaban vulnerando derechos, que hacíamos responsable a la Jueza ante cualquier menoscabo al fondo documental que se encontraba (se encuentra) en manos del Ejército, y que pedíamos la fijación de fecha en forma urgente. Salimos con un sabor amargo.

\section{3.- Análisis}

"Un día yo grité que por qué no podía hablar y al día siguiente me llevaron a un pabellón solo, una habitación con una división, había una pared, y ahi me apretaron, me ordenaron que no hable de nadie, me dijeron que sabían que yo sabía mucho, y que no hablara nunca más de los militares, de lo que pasó y lo que vi, y me hacen firmar un documento." (Denuncia NA)

Los hechos, sucesos, documentos e información que se anudan en la presente investigación no son aislados. No constituyen decisiones individuales o motivaciones subjetivas. Obedecen a una planificación, a diversos momentos que implicaron vulneración de derechos, en concreto, una exteriorización de conducta por parte del Estado.

Las víctimas, muchas de ellas denunciantes en el marco de un expediente judicial, debieron atravesar un duro proceso subjetivo, romper una imposición, una estructura forjada para garantizar el silencio y la impunidad. Es por ello que para la presente investigación, que recoge en su seno documentación inédita, recientemente desclasificada, fue necesario acuñar un concepto, al menos en lo que concierne a la aplicación específica para comprender el proceso de la guerra de Malvinas. 
Por ello, basándome en la idea de caja de herramientas (Foucault, 2000:10), en las tensiones dialécticas entre el fenómeno investigado y la teoría, en ese sistema de relevos (Foucault, 2000: 8); fue imprescindible labrar la noción de tecnologías del ocultamiento, o tecnologías de la impunidad. En efecto, ellas permiten anudar los diversos momentos que permiten comprender los sucesos como crímenes de Estado.

Así, el objeto de la tesis se limita a abordar cómo las Fuerzas Armadas configuraron un dispositivo para silenciar a los soldados conscriptos que habían sufrido torturas y otras graves violaciones a los derechos humanos. Es importante detenerse en ello, pues la reconstrucción de este segundo momento de vulneraciones, engrana sobre otras dos: las torturas propiamente dichas, cometidas por agentes del Estado, y la dificultad u obstáculos para acceder a la justicia (no es menor que a 38 años de finalizada la guerra, recién se hayan dictado los primeros 4 procesamientos sobre un total de 95 militares denunciados).

¿Por qué, entonces, se ha seguido el orden que antecede en torno a la presentación de la información? Pues las tecnologías de ocultamiento o impunidad requieren comprender diversos fotogramas que, dispuestos en orden en el cinematógrafo, arrojan una dimensión real y contundente de los sucesivos y consecutivos actos victimizantes que han sufrido los soldados conscriptos.

El contexto constituye el primer hilo de esta madeja. Una Dictadura cívico/militar, formada en la Doctrina de la Seguridad Nacional. Desapariciones, torturas, robo de bebés, vuelos de la muerte, todas cuestiones que han quedado debidamente acreditadas, desde en el Nunca Más (2016), hasta en la causa 13/84 y las posteriores sentencias que se han dado en los diversos juicios por los crímenes del Estado argentino durante el período 1976-1983. Ese estado criminal, que instrumentó un Plan Sistemático de Exterminio de personas (causa 13/84), fue el que tomó la decisión de llevar adelante una guerra contra el Reino Unido.

Es imprescindible remarcar que regía la supresión del orden constitucional. El Congreso, Poder estatal entre cuyas atribuciones se encontraba la de autorizar al Ejecutivo a iniciar acciones bélicas (artículo 67 Constitución 1853/60, previa a la reforma de 1994), se encontraba cerrado. Además, no era materialmente posible reclamar a las autoridades sin poner en riesgo la vida e integridad personal. 
Galtieri remató aquella conversación con algunas recomendaciones: le pidió que no formara un equipo de colaboradores muy grande porque, al fin de cuentas "gobernar Malvinas es una pavada", le reiteró que debía guardar el mayor de los secretos y sólo estaría autorizado para tomar contacto con el grupo de tareas que preparaba el desembarco cuando recibiera una orden explícita en tal sentido. Una vez en las islas, agregó Galtieri, cualquier problema debía reportarlo a través del general García, titular del V Cuerpo del Ejército con asiento en Bahía Blanca.

Cuando concluyó la conversación con Galtieri, Menéndez se relajó. Si todo se desarrollaba como lo pintaba el comandante, aquello no sería una guerra. Sería un paseo. (Cardoso; Kirschbaum; Van Der Kooy, 1992: 74)

Por su parte, esas Fuerzas Armadas habían sido instruidas en la Doctrina de la Seguridad Nacional. En dicho sentido, a nivel regional se instrumentó un mecanismo de persecución y represión de lo que desde las usinas de pensamiento se había caracterizado como "el enemigo interno". En concreto, la Dictadura argentina estaba formada en la represión y el exterminio de personas. Este punto no es menor, si atendemos a dos cuestiones nodales que se han puntualizado en la presente investigación: a) los soldados conscriptos fueron torturados en modo salvaje y, b) el Informe Rattenbach (junto con otros textos de investigación, como Malvinas: la trama secreta (1992)) dan cuenta de la carencia total de preparación para llevar adelante las acciones bélicas.

Aquí resulta necesario realizar una aclaración. La perspectiva desde la que parto para el desarrollo de esta tesis es la pedagogía y cosmovisión de Paz. Es decir, entiendo que resulta imposible tender al desarrollo y a la plena vigencia de los derechos humanos en un contexto de guerra. No obstante, debo puntualizar la impericia de las Fuerzas Armadas al momento del diseño de la estrategia y el despliegue táctico, dado que ello permite reconstruir las finalidades trazadas por la Doctrina de la Seguridad Nacional.

Dicho esto, llegamos a un punto central. El 2 de abril de 1982 se produjo el desembarco en Malvinas. Las Fuerzas Armadas decidieron llevar a la guerra a jóvenes de distintos puntos del país que no habían optado por la carrera militar, que se encontraban obligados, compelidos por una norma a realizar el servicio militar obligatorio. A ello debe añadirse que, merced a las falencias estratégico/tácticas, parte de los soldados arrastrados 
a la guerra habían sido dados de baja (clase 1962), y los de la clase 1963 no habían completado la instrucción militar.

A ese cóctel debe adicionarse el paupérrimo equipamiento. Vestimenta inadecuada (desde el camuflaje hasta el abrigo), armamento obsoleto y no idóneo, entre otras de las cuestiones que emergen de los sucesivos relatos a los que he estado expuesto en casi una década de trabajo con el colectivo de excombatientes (conscriptos), como también de la documentación oficial (vg. Informe Rattenbach). En ese marco se dieron las torturas. Quedará para futuras investigaciones la pregunta en torno a si no constituye en sí mismo una práctica tortuosa el disponer de la vida de personas en dichas condiciones.

Lo concreto es que los soldados fueron torturados. Dichas violaciones a los derechos humanos se dieron, básicamente, como respuesta a dos cuestiones: frente a algún reclamo por padecimiento de frío, hambre o cansancio extenuante; o bien como represalia por procurar alimento. En algunos casos, estas torturas obedecieron a cuestiones religiosas (testimonio BA). Nótese la amplificación de las prácticas abominables. Se "castigó" (el término es torturó) a personas famélicas, a jóvenes que padecían frío (la época elegida por la Dictadura habla en sí misma de la impericia de la Comandancia). Es extraño y hasta contraintuitivo pensar en unas Fuerzas Armadas que procedan así durante el desarrollo de una guerra, que menoscaben a sus propios combatientes sometiéndolos a tortura. Pero ello sucedió. 120 testimonios obran en el Poder Judicial (Justicia Federal) y dan cuenta de ello. En las tres Armas, en diversas unidades militares, a lo largo y ancho del Teatro de Operaciones del Atlántico Sur (TOAS).

La naturaleza jurídico-internacional de los delitos es también, un terreno prolífico para la continuidad y/o emergencia de nuevas investigaciones (amén de las que ya están sucediendo en el plano judicial). Lo cierto es que se trató de torturas: estaqueamientos; enterramientos de soldados desnudos hasta el cuello; obligación a soldados a sumergirse desnudos en agua helada; obligación a introducir miembros superiores -manos- o inferiores -pies- en agua helada; aplicación de picana con teléfonos de campaña; golpizas y prácticas de tormentos; amenazas con armas de fuego (abuso de armas, incluso en algunos casos con disparos incluidos); entre otras.

Si se dispusieran las violaciones a los derechos humanos en una línea de tiempo, aquí se producen las primeras, los hechos germinales que, a su vez, como si se tratase de un juego de muñecas rusas, darían lugar a nuevas y sucesivas vulneraciones. Los agentes 
de un Estado criminal, en medio de una guerra ilegítima (declarada por un gobierno de facto), llevaron adelante las prácticas de tortura.

Con posterioridad, y a partir de los relatos que emergieron durante y, sobre todo, una vez finalizadas las acciones bélicas, fue el mismo Estado el que montó las tecnologías del ocultamiento (o tecnologías de la impunidad). ¿Cómo lo hizo? Para caracterizarla es importante echar mano a la documentación a la que he accedido merced a la desclasificación de archivos oficiales relativos al conflicto bélico del Atlántico Sur. A su vez, resulta importante el entrecruzamiento con los testimonios de las víctimas, muchos de ellos obrantes en el expediente judicial (causa 1.777/07 en trámite ante el Juzgado Federal de Río Grande, Tierra del Fuego, Antártida e Islas del Atlántico Sur).

Lo primero que debe ser puntualizado es aquello que sobrevuela la presente investigación. Como vimos, el Informe Rattenbach, desclasificado en 2012, da cuenta de la falta de capacitación y adiestramiento "para sostener un conflicto bélico de la magnitud y características del que se llevó a cabo". Quedan en claro, tres puntos nodales, que sirven como plafón interpretativo: a) las Fuerzas Armadas argentinas estaban formadas para la represión de lo que regionalmente se había caracterizado como enemigo interno; b) el descrédito social e internacional respecto de la Dictadura que, para 1982 se había instalado, llevó a tomar la decisión de la guerra, con la finalidad de generar la hipótesis del enemigo externo (D’Andrea Mohr, 1998); c) la vocación de Leopoldo Fortunato Galtieri de generar un hecho que permitiera "blanquear" su imagen y eventualmente presentarse a elecciones en una suerte de "transición democrática" (Cardoso; Kirschbaum; Van Der Kooy, 1992).

Retomo estas tres líneas, pues son importantes para comprender, en parte, cómo las Fuerzas Armadas intentaron, con Malvinas, resignificar su imagen. La emergencia de relatos de tortura a los soldados conscriptos, ponía (y pone hoy -en las pujas semióticas) en jaque dicha vocación. Aquí se produce el primer giro importante en la hermenéutica cultural. La Dictadura también fue Malvinas, o bien, Malvinas también fue la Dictadura. El relato de la gesta heroica, veremos, fue un mecanismo, un dispositivo pensado. El ocultamiento de los hechos de tortura no cuadraba con el mismo. Sin embargo, si vamos a la lógica más elemental, resulta un contrasentido siquiera imaginar que hasta las 23:59 del $1^{\circ}$ de abril de 1982 regía un gobierno genocida, y desde las 00:00 del 2 de abril, un gobierno heroico, patriota y probo. Esta tesis pretende deconstruir ese doble estándar que es, también, parte de la lógica de sojuzgamiento a las víctimas. 
¿Sabían las Fuerzas Armadas que en Malvinas se había torturado a soldados? Sí. En primer término, como se ha dicho, las torturas fueron cometidas por Oficiales y Suboficiales, y en pleno conocimiento/anuencia/aliento de la cadena de mando. A su vez, los soldados, al regreso de Malvinas, dejaron plasmadas estas experiencias en las actas de recepción. Estos documentos, hoy desclasificados, permiten ver cómo los soldados relataron los hechos que habían padecido. Ya el hecho de haber centralizado el regreso permite ver una organización tendiente a controlar todas las instancias de información, y uniformar el relato. Frente a ello, las tecnologías del olvido (o impunidad) se instrumentaron de dos formas.

Desde antes de finalizada la guerra (1982), se dispusieron dispositivos sobre el relato. En el desarrollo de la presente se puede ver el "Acta disponiendo el control de la información por razones de seguridad nacional", firmada por el Estado Mayor Conjunto y que, como se puntualizó, estaba orientada a ordenar la comunicación externa y hasta disponía sanciones para los medios de comunicación. A su vez, se configuraron mecanismos para con los soldados, como el "Informe de experiencias" del 8 de junio de 1982, en el que se establecen "actividades de acción sicológica". En este último documento se daba cuenta del "mal trato recibido" y de "los castigos corporales".

Por su parte, los documentos no sólo se quedaron en el diagnóstico. En el documento analizado se diseña y ordena la implementación de una campaña de Acción Sicológica preventiva a nivel individual sobre los internados a fin de evitar el efecto "bola de nieve" que trae como consecuencia los comentarios por ellos realizados. También se ordena la puesta en conocimiento a los Comandantes o Jefes de los comentarios o declaraciones hechas por sus subordinados. De esto se desprenden tres aspectos: a) el conocimiento y consecuente responsabilidad de la cadena de mando; b) el diseño de una tecnología (técnica y lógica) tendiente a evitar la proliferación de relatos $\mathrm{y}$; c) la dimensión subjetiva, al constatar en los testimonios cómo los soldados fueron obligados a guardar silencio ("me hicieron firmar" es tal vez la expresión más recurrente, la aludida saturación de la muestra).

En la misma línea debe leerse la Orden Especial N 22/82 del Comando Cuerpo del Ejército (medidas de contrainteligencia) que prohíbe al personal efectuar declaraciones o presentarse a reportajes. El Poder de ese Estado criminal ordenando el silencio. O la Orden Especial N ${ }^{\circ}$ 4/82 del Jefe del V Cuerpo Comando del Ejército, en cuyo Apéndice 1 se ordena (bajo la idea perversa de "la PATRIA requiere otro esfuerzo") no proporcionar 
información; no ser imprudente en juicios y apreciaciones; no dejarse llevar por rumores; y perpetuar la forma heroica como [los] soldados dieron su vida por la soberanía nacional.

La potencia del relato es aquí patente. Si todos son héroes, el costo de ir contra dicho mandato es altísimo. No sólo existió una imposición individual. También la hubo con la lógica de “cuerpo". Hablar era traicionar a ese grupo. El héroe, inmortalizado en el bronce, no siente, no llora, no sufre. Los relatos sobrevinientes de la gesta heroica, son parte de las tecnologías del olvido y la impunidad. Hay allí un juego perverso entre la subjetividad y la trama, una apuesta a recrear un estado de situación en que cobre potencia la mirada del grupo social, una estrategia de control multipolar sobre los discursos circulantes y las personas. En dicha concepción, considerarse víctima implica dinamitar ese constructo de heroicidad premoldeado. Lo más complejo, es que al hacerlo se deja al desnudo a los demás. ¿Hubo torturas para todos? Si uno fue víctima y sufrió... ¿Todos lo fueron y padecieron?

En virtud de esta línea argumentativa, es importante retomar la lectura de la ya citada "Cartilla de recomendaciones de contrainteligencia", ahora con resaltados propios (en negrita):

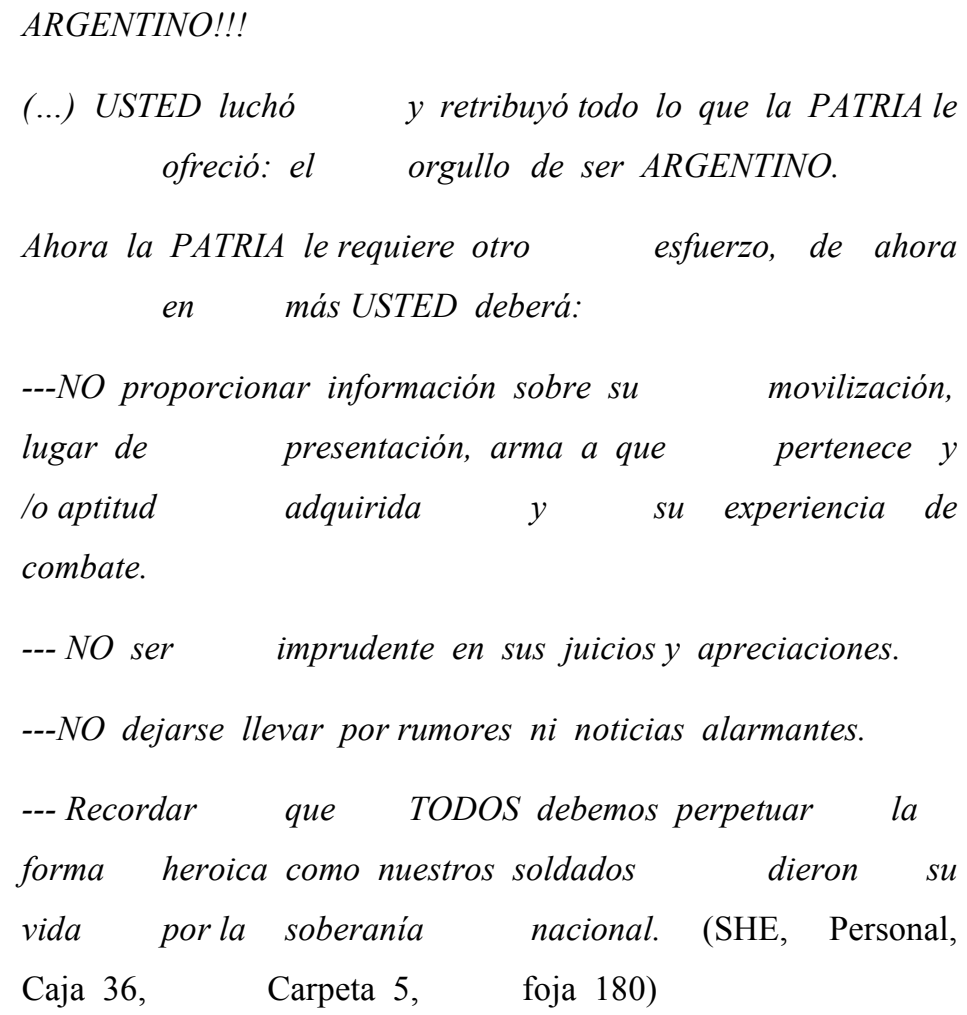


A ello debe añadirse, en una lectura contextualizada de todas las fuentes, la orden firmada el 30 de diciembre de 1982 por el entonces Jefe del Ejército, Cristino Nicolaides. Allí, en conocimiento de las torturas, que en el documento se denominan infracciones, indica dar tratamiento a las mismas dentro del ámbito disciplinario. Sí, equipara quedarse dormido en una imaginaria ${ }^{39}$, a haber estaqueado soldados a quienes, estando en dicha situación, los mató una munición de mortero (testimonio de NA, incorporado al expediente 1.777/07). A su vez, Nicolaides llama a moverse con mesura y a guardar la adecuada reserva.

Es importante, dicho esto, retomar la lectura de la pieza procesal por la que la Magistrada Borruto (Juzgado Federal de Río Grande, 2020) procesó a los 4 primeros militares por el delito de tortura (imposición de tormento, amenazas y abuso de armas):

no puede negarse que los imputados actuaron en conocimiento y bajo el amparo de un sistema que había suprimido las garantías de los ciudadanos en general y que impedía toda posibilidad de reclamar contra las acciones ilegítimas de los miembros de las Fuerzas Armadas. (Juzgado Federal de Río Grande, 2020: 23)

El aludido sistema es, en parte, lo que en la presente investigación se denomina tecnologías del ocultamiento (o tecnologías de la impunidad). En su cuarta acepción, la Real Academia Española define el vocablo tecnología como el "Conjunto de los instrumentos y procedimientos industriales de un determinado sector o producto". Tomaré lo relativo a los instrumentos y procedimientos utilizados por la dictadura para lograr un producto: la impunidad.

Foucault explica que el individuo es el resultado de algo que le es anterior: el mecanismo, todos los procedimientos que fijan el poder político al cuerpo (Foucault, 2008: 78). Existe aquí, como se ha visto, un mecanismo, que he llamado tecnología, un conjunto de lógicas y prácticas tendientes a gestar un sujeto emergente.

\footnotetext{
${ }^{39}$ Guardia o vigilancia que varios soldados realizan por turnos en el lugar donde duermen sus compañeros.
} 
El poder disciplinario es individualizante porque ajusta la función sujeto a la singularidad somática por intermedio de un sistema de vigilancia y escritura o un sistema de panoptismo pangráfico que proyecta por detrás de la singularidad somática, como su prolongación o su comienzo, un núcleo de virtualidades, una psique (Foucault, 2008: 77)

Los procedimientos aludidos, como he afirmado, apuntaron a crear un sistema multipolar. Supresión de garantías, edificación de mecanismos burocráticos para dar curso a las denuncias, centros de recepción de combatientes, actas y documentos (protocolización e instrumentación de dicha tecnología, la escritura a la que alude Foucault (2008)), acción psicológica, acciones de inteligencia y contrainteligencia, disposiciones respecto a los discursos, control sobre el colectivo de combatientes, estrategias de vigilancia sobre noticias e información en los medios de comunicación. Todas estas dimensiones han sido abordadas y respaldadas por fuentes: testimonios, documentos oficiales, publicaciones, declaraciones públicas.

En lo que atañe al control sobre el colectivo de excombatientes, resulta interesante remarcar los hallazgos en torno al seguimiento que se realizó sobre el Centro de Ex Combatientes Islas Malvinas La Plata.

Como ejemplo de esta actividad de inteligencia sobre las organizaciones de ex combatientes existe un informe elaborado por la Comisión Especial Malvinas del 21 de diciembre de 1989 ante la publicación del libro "informe Rattenbach, el drama de Malvinas", patrocinado por el Centro de Ex Combatientes de La Plata (CECIM). En el Anexo 2 consta un informe de inteligencia sobre dicha organización, se registra la constitución para 1982 y la finalidad: de nuclear los ex combatientes y brindarles apoyo sicológico, laboral y jurídico. La tendencia ideológica es definida como "izquierdista, y en tanto cuenta con el apoyo de partidos de izquierda, organizaciones de solidaridad y entidades de derechos humanos". Hay además un análisis de los antecedentes de cada uno de los integrantes del Consejo Directivo como también de las diferentes actividades que realizaron. SHE, CEM, Caja 3, Carpeta 13) 
Por otro lado, en un informe firmado por el cnl (R) Miguel Raúl GENTIL de la Comisión Especial Malvinas, del 9 de septiembre de 1992, se comunica al Subjefe del EMGE sobre los antecedentes de denuncias por fusilamientos de soldados argentinos en las Islas Malvinas ante la publicación del libro "Viaje al infierno" de Vincent Bramley. EN el documento se informa que el CECIM "está integrado en su mayoría por ex combatientes enrolados en las filas del PC y del MAS, los que publicaron una versión tergiversada del informe RATTENBACH (...). El mencionado centro no desperdicia oportunidad de denostar al EA y en especial a sus superiores". Más adelante, se citan las declaraciones hechas por ex conscriptos de diferentes unidades de las Fuerzas Armadas. Por último, en el Anexo 7 del informe están los antecedentes del CECIM, donde se informaba quienes eran su presidente, su vicepresidente, las actividades que desarrollaban y de las que participaban. También hay copias de los sus relatos testimoniales compartidos por ellos en el XII Festival Mundial de la Juventud y los Estudiantes, realizado en Moscú en julio de 1985. (SHE, CEM, Caja 2, Carpeta 10) (Equipo de Relevamiento y Análisis de los Archivos del Ejército, 2016a: 13-14)

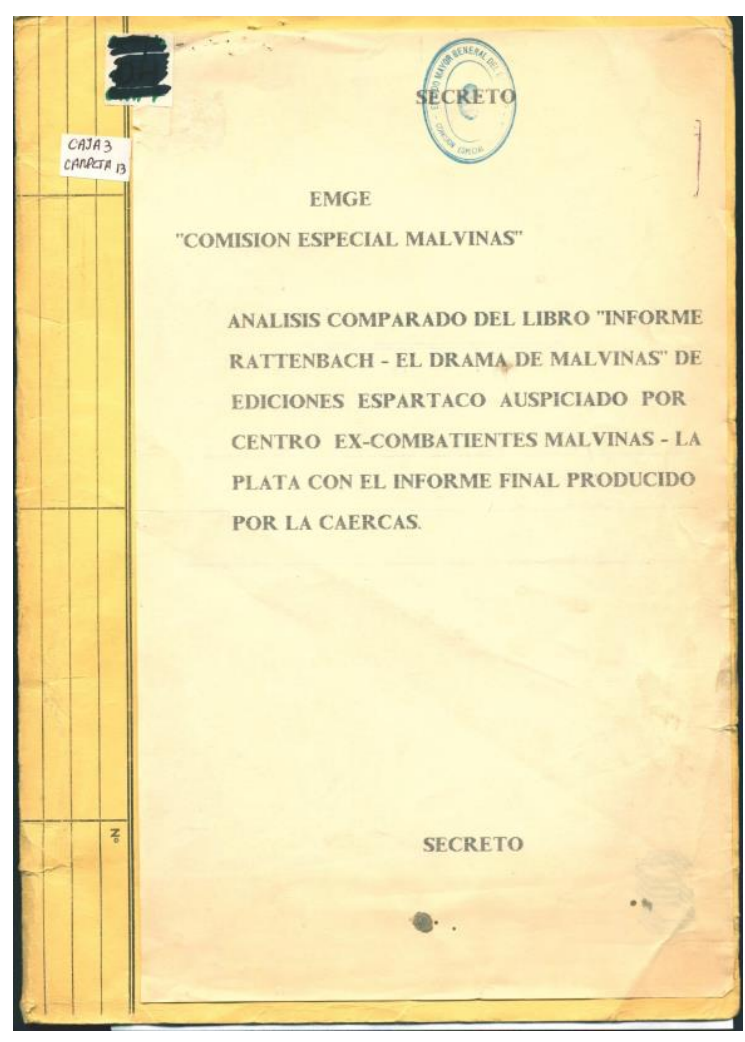




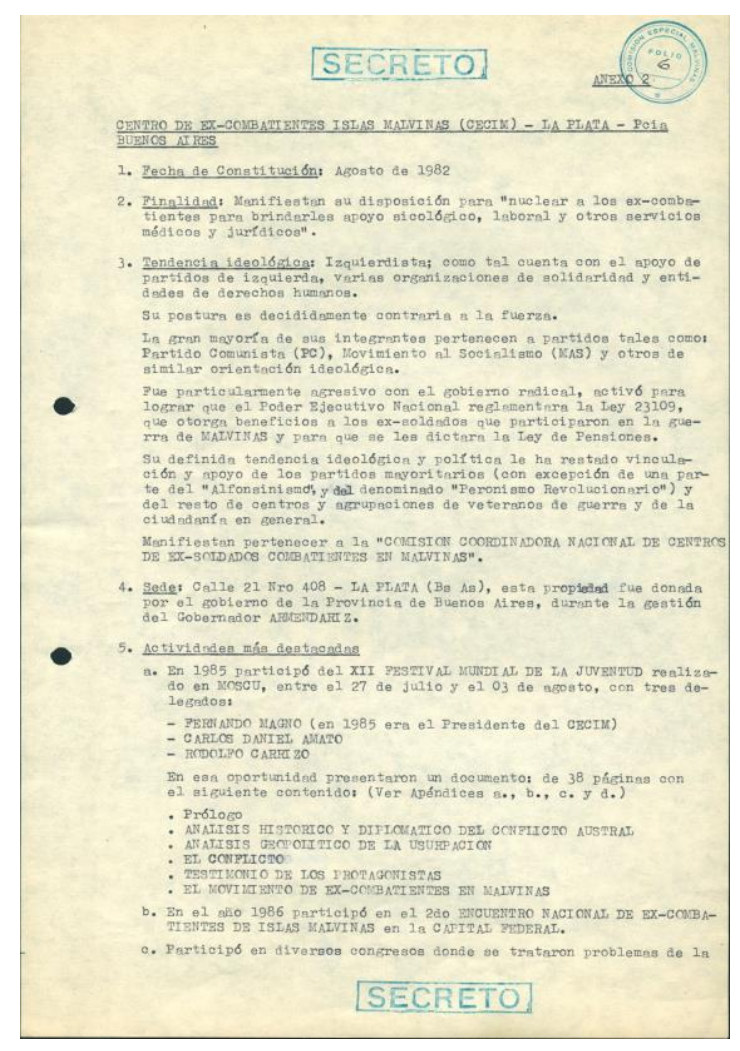

Por su parte, amén del tratamiento mediático de la guerra de Malvinas, del "Estamos ganando" de Revista Gente, u otros artículos periodísticos, cuestión sobre la que se ha escrito mucho y que, en términos documentales, ha quedado bien plasmado en "Decíamos Ayer. La prensa argentina bajo el Proceso" de Eduardo Blaustein y Martín Zubieta (1998), es importante apreciar cómo determinados medios de comunicación continúan con líneas editoriales análogas a las trazadas por la Dictadura.

Así, los artículos periodísticos citados en esta investigación, dialogan a la perfección con las declaraciones del Jefe del Ejército, Claudio Pasqualini. Por ello forman parte del corpus a analizar. La potencia de las tecnologías del ocultamiento (o tecnologías de la impunidad) persiste hasta nuestros días. Veamos. Hasta 2007 fue casi imposible concebir el desarrollo de una causa penal. Es cierto, en la República Argentina rigieron, hasta $2003^{40}$ las leyes de punto final (Ley 23.492, promulgada el 24 de diciembre de 1986), y de obediencia debida (Ley 23.521, promulgada el 8 de junio de 1987). Sin embargo, Malvinas y las violaciones a los derechos humanos que allí se cometieron no

\footnotetext{
${ }^{40}$ El 21 de agosto de agosto de 2003 se sancionó la Ley 25.779 que declaró insanablemente nulas las Leyes 23.492 y 23.521. La mentada norma fue promulgada el 2 de septiembre de 2003.

Posteriormente, en 2005, La Corte Suprema de Justicia de la Nación, en el fallo "Simón, Julio Héctor", declaró inconstitucionales las leyes de punto final y obediencia debida (23.492 y 23.521 respectivamente) y declaró la validez de la Ley 25.779 .
} 
fueron incorporadas a los Juicios por la $V_{e r d a d}^{41}$, ni se incluyeron inicialmente en las agendas reivindicativas. En gran parte, ello se debió a las dificultades que experimentaron las víctimas para hablar de lo que había sucedido.

A su vez, la causa lleva 13 años de vida. A la fecha, sólo se han dictado 4 procesamientos, y hay aún 20 llamados a prestar declaración indagatoria sobre los que resta fijar fecha. Recordemos, en este punto, que son 95 los militares denunciados por 105 casos. Ello sin contar que, al momento de esbozar estas líneas analíticas está pendiente el trámite de la Petición P-465 ante la Comisión Interamericana de Derechos Humanos por privación de los derechos/garantías de acceso a la Justicia, contemplada en los artículos 8 y 25, ambos en relación con el artículo $1^{\circ}$ de la Convención Americana de Derechos Humanos.

Estas acciones, la penal, en el ámbito de la Justicia Federal argentina, y el fuero internacional, constituyen arietes tendientes a desguazar las tecnologías de olvido (impunidad) trazadas por la dictadura. Al igual que la presente investigación que, en la reconstrucción de los dispositivos aludidos, pretende despejar cualquier duda respecto a los crímenes de Estado cometidos por la dictadura, cuyas víctimas resultaron ser los excombatientes. Ojalá algún día, los elementos aquí presentados puedan servir en eventuales alegatos y/o fundamentos de sentencias.

\section{1.- Sinopsis: Diagrama de logística probatoria basada en evidencia para la hipótesis original}

\footnotetext{
41 “La sanción de las leyes de obediencia debida y punto final provocó que un gran número de las causas penales que se habían abierto con el fin de investigar los hechos cometidos durante la última dictadura militar quedaran paralizados, hasta que, en cumplimiento de las recomendaciones de la Comisión Interamericana de Derechos Humanos para que el Estado argentino garantizara los reclamos de verdad (Informe 28/92), se realizaron los procesos conocidos como juicios de la verdad.

Así transcurrió una primera etapa, en la que se consideró suficiente el mero "esclarecimiento" de los hechos como forma de cumplimiento de los deberes (y las facultades) del Estado argentino en esa dirección." Cita disponible en https://www.cij.gov.ar/lesa-humanidad.html [Acceso 26/3/2020].

En el Informe $\mathrm{N}^{\circ}$ 28/92 de la Comisión Interamericana de Derechos Humanos (2 de octubre de 1992), relativo a los casos 10.147, 10.181, 10.240, 10.262, 10.309 y 10.311, el organismo recomendó al Estado argentino: "la adopción de medidas necesarias para esclarecer los hechos e individualizar a los responsables de las violaciones de derechos humanos ocurridas durante la pasada dictadura militar." Punto 3 de las recomendaciones, informe 28/92 de la CIDH.
} 


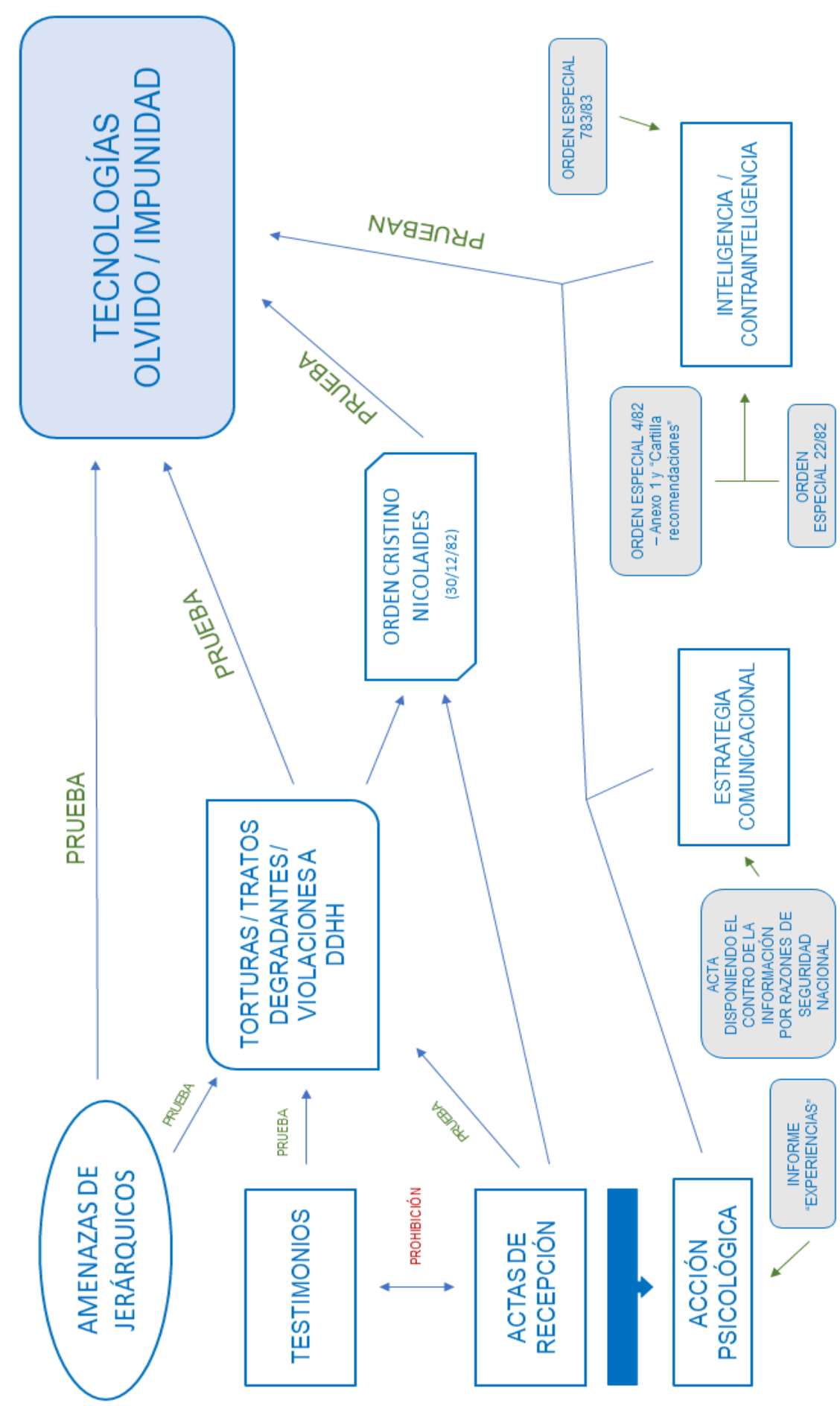




\section{Nota de campo 10: denuncia $N A$}

16 de mayo de 2019. 10:30. 21 y 40. Sede del CECIM La Plata. Laurentina, Ernesto (Beto) y yo. Esperábamos a NA. Llegó. Unos días antes había hablado varias horas con Beto contándole lo que había vivido en Malvinas. Charlamos un poco. Se había animado a hablar luego de ver los llamados a indagatorias. Eso lo había alentado. Quería interiorizarse sobre posibles consecuencias jurídicas. Con Laurentina le explicamos algunas cuestiones. Quería denunciar. Tomé mi computadora. Mientras la preparaba, Ernesto hizo un mate y trajo un vaso de agua. Abrí un archivo de texto en blanco. NA comenzó a hablar. En estos apuntes, a vuelapluma se intercalan fragmentos de su testimonio.

"Que en la posición que ocupé en Malvinas tenía como jefes, a un Sargento, cuyo nombre no recuerdo; al cabo Colombera y el cabo Romano. Había otros, pero los nombres no recuerdo. Como Oficial responsable del grupo, estaba el Subteniente Menéndez.

Aproximadamente a los 15 días de haber arribado a Puerto Yapeyú comenzaron las torturas. Te apuntaban con el FAL, con la pistola en la boca, que nos decían "tenés hambre, abrí la boca" y nos apuntaban; también nos daban patadas.

Que había una casilla, en la que colocaron una carpa, que había fuego adentro, estaba calefaccionada. Yo me acerqué, les dije que había fuego, que por qué no teníamos...

El subteniente Menéndez me respondió "tenés frío", y me puso los pies al costado del fuego, con los borceguíes y las medias y me ordenaron no moverme. Me tuvieron un día entero con el fuego. Que salí de ahí sin poder caminar, que el fuego me hizo ampollas en los costados de los dos dedos grandes por las quemaduras.

Unos días después de lo que sucedió con el fuego, el cabo Romano me apuntó con el arma, yo estaba sentado en mi posición, y me disparó en la pierna porque no podía caminar. El disparo me pegó en la pierna izquierda. Que tengo la cicatriz en mi muslo.”

Luego, nos refirió que había visto morir a dos compañeros a quienes, estando estaqueados, les había caído una bomba. Eso le valió que lo llevaran a hacer una guardia. Bajo ese pretexto pretendieron dejarlo abandonado. Las heridas en los pies le impidieron volver. Fue rescatado por miembros de las Fuerzas Armadas británicas En numerosas oportunidades pretendieron hacerlo callar. Le impusieron el silencio. Queda claro cuando habla. Sin embargo, contra los deseos de aquellos artífices del horror, 
ha roto la espiral de silencio. Está denunciando. Las palabras brotan de su boca. Cada tanto llora. Toma agua. Pide disculpas. Le repetimos, una y otra vez, que no tiene que disculparse. Que se tome el tiempo necesario para recordar. Y allí retoma. Los detalles, cuando agentes de la SIDE (Secretaría de Inteligencia del Estado) lo esperan en Chaco, en la localidad de Las Breñas (NA había ido a visitar a su familia luego de la guerra), y le dicen que sólo puede estar dos días y que no debía contar nada de lo sucedido.

Con Laurentina y Ernesto nos mirábamos. Nuestras gargantas, anudadas. No se pierde la capacidad de asombro, la impotencia y la bronca ante el horror. Menos, cuando el sufrimiento humano se manifiesta ante los ojos, en carne viva. Los padecientes hablan más allá de sus palabras. Sus gestos, su mirada, los silencios y suspiros. Uno tipeando, convirtiendo ese sufrimiento en un documento judicial o judicializable. Adaptando lo inadaptable a las lógicas del campo. A los requerimientos formales. "Formula denuncia", "V.S.". Se hace difícil encontrar sentido a esas lógicas cuando lo abominable cobra corporeidad con cada significante. Las torturas, como abstracción jurídica son estaqueamientos, el quemar los pies de una persona que dice padecer frío, el ver a sus compañeros morir por una bomba encontrándose estaqueados, o que te pongan un FAL en la boca al requerir algo tan básico como alimentos.

NA estaba hablando. La historia estaba hablando. Unas condiciones sociales, culturales que hacían que él hubiese decidido hablar primero con su familia, buscar un teléfono de contacto con el CECIM, hablar largas horas con Beto, contarle a él, poner en palabras sus vivencias, viajar a La Plata (vive en otra localidad), hablar con Laurentina, con Jerónimo, dos desconocidos, dos abogados de un organismo en que depositó la confianza, romper el cerco, romper la imposición, hablar. Llorar y hablar. Sacar afuera. Volver a pasar por el corazón. Poner el cuerpo. Ir contra los dispositivos de control. Entregarse con arrojo a la incertidumbre de si, aquellos torturadores, volverían por él en cumplimiento de sus promesas.

NA estaba ahí. Yo estaba ahí. Laurentina y Beto estaban ahí. Esa comunión de personas. Nuestras historias a cuestas. La historia de la causa a cuestas. Nuestras obsesiones, nuestras frustraciones. Nuestros comienzos (estamos siempre partiendo, nunca llegando). Nuestros triunfos y derrotas. NA depositando en nosotros la confianza. La responsabilidad de luchar y dar respuesta. Creo que nunca nada ha sido tan fuerte. Un mandato implícito de alcanzar justicia. Por él. Por lo que padeció, y porque nos eligió para canalizar su reparación. Que es también nuestra. Que es ahora nuestra. 
Imprimimos el escrito. Lo ensobramos. Lo enviamos por correo. Hoy hay procesados por las torturas a NA. Y por las torturas a otros exsoldados combatientes de Malvinas. Hubo que destruir la tecnología del olvido. Al menos, alguno de sus engranajes. La lucha sigue...

\section{4.- Conclusiones}

Para el desarrollo de la presente investigación se partió de la siguiente hipótesis:

Las Fuerzas Armadas instrumentaron, durante y después del hecho bélico que protagonizó la República Argentina con el Reino Unido, un dispositivo político/burocrático $^{42}$ que garantizara dejar impunes las graves violaciones a los derechos humanos cometidas en perjuicio de los soldados conscriptos, y construir ante la opinión pública el relato de la guerra en tanto "gesta heroica".

Estos mecanismos serán nombrados en forma indistinta como tecnologías de la impunidad o tecnologías del ocultamiento.

Dicha hipótesis, a modo de recorte sobre el objeto de estudio, excluyó dos dimensiones que se abordan tangencialmente. La primera, la naturaleza jurídica/penalinternacional de los delitos abordados. Como se ha esbozado a lo largo de la investigación, las torturas y otros tratos inhumanos se caracterizan como crímenes de lesa humanidad, pese a que existen algunas posturas que tienden a encuadrarlos como crímenes de guerra ${ }^{43}$. Dicha temática, importante, no se pone en tensión en la tesis. Es, así, insumo para nuevas y futuras investigaciones en el campo del derecho, y del derecho internacional de los derechos humanos.

La segunda, también trascendente, es el interrogante en torno a los porqués de las torturas. Las motivaciones corporativas y/o individuales que puedan haber tenido los artífices de las torturas, sin embargo, no han quedado por fuera del proceso de producción académica. A lo largo del trabajo sostengo que la Dictadura también fue Malvinas. Y la

42 Como se ha manifestado, el término hace referencia a la trama burocrático/administrativa/conductual/corporativa desplegada por las Fuerzas Armadas durante la guerra de Malvinas y, sobre todo, una vez finalizado el conflicto, con el objetivo de silenciar a los soldados conscriptos que habían padecido, en forma consecutiva, las falencias propias de la organización de la "aventura militar" (Informe Rattenbach), y las torturas, vejámenes y malos tratos propinados por sus superiores.

${ }^{43}$ Así lo sostiene, por ejemplo, el Fiscal de Casación Javier De Luca. 
aplicación de torturas es una constante en el proceso histórico abordado. Para caracterizar las posibles motivaciones para la aplicación de tormentos en el contexto específico del momento de desarrollo del conflicto armado, se utilizaron las reflexiones de Maneiro (2005). Además, considero que ha quedado de manifiesto que las Fuerzas Armadas argentinas estaban formadas para la represión de lo que regionalmente se caracterizó como el "enemigo interno". Respecto de este punto, considero que lo que torna más incomprensible el uso de estas prácticas durante el conflicto es lo inconcebible del debilitamiento de la "tropa propia", que claramente estaba en inferioridad de condiciones materiales y subjetivas.

Estas aclaraciones son centrales para situar el foco en corazón de la tesis. A su vez, como se ha mencionado en algún pasaje, existe un deseo concomitante, tendiente a que el presente trabajo académico pueda servir de prueba en el proceso penal. De allí, que las necesidades concretas que han surgido en el desempeño de la abogacía, a partir de la pericia incorporada luego de haber atravesado las cursadas de la Maestría en Derechos Humanos de la Facultad de Ciencias Jurídicas y Sociales de la Universidad Nacional de La Plata, tornaron indispensable reparar en el accionar estatal de todo lo que concierne al ocultamiento.

¿Por qué hablar de las torturas en Malvinas como crímenes de Estado? ¿De dónde surge la responsabilidad estatal? ¿Por qué ha costado tanto lograr avances en el campo del derecho penal? Esos interrogantes guiaron, durante muchos años, el quehacer jurídico. Sin embargo, necesitaban una respuesta. Unas herramientas (Foucault, 2000:10) idóneas para hilvanar sucesos, para dar un marco global de sentido a los hechos aislados, a esas torturas que devinieron en ordenes de silencio, en la redacción de actas. Un sintagma, una expresión que nos permitiera contener todo el Nilo en la palabra "Nilo" (Borges, 1964)

\author{
Gradualmente se vio (como nosotros) \\ aprisionado en esta red sonora \\ de Antes, Después, Ayer, Mientras, Ahora, \\ Derecha, Izquierda, Yo, Tú, Aquellos, Otros. \\ (Borges, 1964)
}


Dicha red sonora, tecnologías de ocultamiento, tecnologías de impunidad, ahora se colman de significado. Permiten apreciar la corporeidad de las actas, la redacción de las órdenes, las amenazas cursadas a los exsoldados combatientes de Malvinas. A instancias de la documentación, testimonios, artículos periodísticos y declaraciones públicas aquí recogidas y presentadas, se comprueban, uno a uno, los supuestos que guiaron la producción académica.

Los soldados conscriptos constituyeron la última víctima colectiva de la Dictadura del "Proceso". El mismo Estado que los torturó, fue el que los obligó a callar. Para ello, se valió de unos dispositivos multipolares. Se libraron órdenes y disposiciones por las que, en forma consecutiva, se instrumentaron sitios destinados a la recepción de los soldados, directrices de acción psicológica y contrainteligencia, un relato monolítico destinado a narrar Malvinas como una gesta heroica, que se vio plasmado en lógica hacia (para con) el colectivo, y en los medios de comunicación, entre otras.

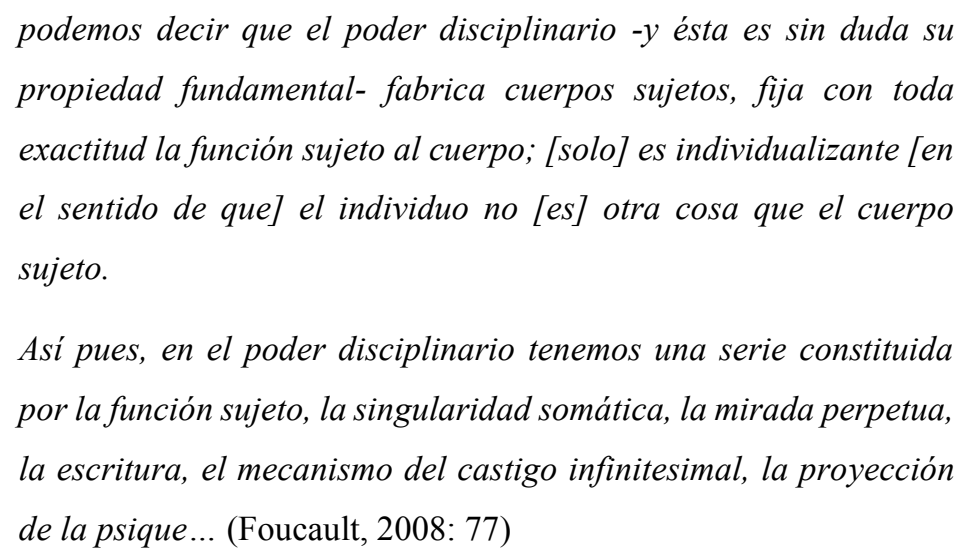

El producto que buscaron las Fuerzas Armadas fue el "Rambo". Un héroe granítico, inmortalizado en el bronce de sus veintitantos años, orgulloso de la milicia, chauvinista. Una persona alienada, producida en serie en los laboratorios de los Centros de Recuperación de Ex Prisioneros de Guerra (CREPG), o de los Centros de Apoyo a la Recuperación Integral (CARI) y de los Centros de Recuperación del Personal de la Fuerza (CRPF).

Habría, por decirlo así, una especie de tenaza jurídico-disciplinaria de individualismo. Tenemos al individuo jurídico tal como aparece 
en esas teorías filosóficas o jurídicas: el individuo como sujeto abstracto, definido por derechos individuales, al que ningún poder puede limitar salvo si [él] lo acepta por contrato. Y por debajo de ello, junto a ello, tenemos el desarrollo de toda una tecnología disciplinaria que puso de manifiesto al individuo como realidad histórica, como elemento de las fuerzas productivas, como elemento, también, de las fuerzas políticas; y ese individuo es un cuerpo sujeto, atrapado en un sistema de vigilancia y sometido a procesos de normalización. (Foucault, 2008: 79)

el individuo disciplinado es un individuo alienado, sojuzgado, un individuo que carece de autenticidad; raspadlo o, mejor, devolvedle la plenitud de sus derechos, y encontraréis, como su forma originaria viviente y vivaz, un individuo que es el individuo filosófico-jurídico. (Foucault, 2008: 80)

No quedan dudas acerca de su planificación y diseño. Tampoco de cómo las diversas piezas del rompecabezas hacen sentido cuando son dispuestas en forma sistemática. Menos de sus resultados concretos. A 38 años de finalizada la guerra de Malvinas, y 13 de iniciada la causa por torturas cometidas por miembros de las Fuerzas Armadas argentinas en perjuicio de los exsoldados combatientes de Malvinas la regla es la impunidad. Una impunidad lacerante. Impunidad sin sentido ni sustento. Hay pruebas de todo tipo: documentos oficiales, testimonios de los protagonistas, análisis contextuales. Sin embargo, hay algo, que paulatinamente comienza a resquebrajarse, pero que aún hoy representa un obstáculo: las tecnologías de la impunidad o tecnologías del ocultamiento. 


\section{5.- Referencias}

Ahmed, J. (2010). Documentary Research Method: New Dimensions. https://www.researchgate.net/publication/227441751_Documentary_Research_Me thod_New_Dimensions (Acceso 11 de abril de 2020)

Alberdi, J. B. (2007). El crimen de la guerra. Terramar.

Arias, A. C., \& López, M. D. (2016). Indisciplinas. Reflexiones sobre prácticas metodológicas en Ciencias Sociales (A. C. Arias \& M. D. López (Eds.)). Club Hem Editores e Instituto de Investigaciones en Comunicación (IICOM-UNLP).

Bauer, T. (2005). Iluminados por el fuego.

Bebilaqua, G. (2010). Del levantamiento al golpe... (y viceversa): el "Operativo Cóndor Azul". Actas de las V Jornadas de Trabajo sobre Historia Reciente. https://www.academia.edu/39161955/Del_levantamiento_al_golpe..._y_viceversa_ el_Operativo_Cóndor_Azul_(Acceso 11 de abril de 2020)

Bertaccini, R. (2012). Malvinas: descolonización, paz y soberanía. Ediciones CTERA.

Blanco, C. (2010). La vigilancia epistemológica en Ciencias Sociales: un compromiso ineludible. Reflexiones desde la sociología del conocimiento de Pierre Bourdieu (Primer Simposio Internacional Interdisciplinario Aduanas Del Conocimiento).

Blaustein, E., \& Zubieta, M. (1998). Decíamos ayer. La prensa argentina bajo el Proceso. Ediciones Colihue S.R.L.

Bogdan, R., \& Biklen, S. (1992). Qualitative research for education: An introduction to theory and methods. Allyn \& Bacon.

Borges, J. L. (1964). El golem. In El otro, el mismo. https://www.poeticous.com/borges/el-golem?locale=es (Acceso 11 de abril de 2020)

Bravo, N. (2003). El discurso de la dictadura militar argentina (1976-1983): Definición del opositor político y confinamiento-"valorización" del papel de la mujer en el espacio privado. Utopía y Praxis Latinoamericana, 107-123. https://ri.conicet.gov.ar/bitstream/handle/11336/95862/CONICET_Digital_B.pdf?s equence $=5 \&$ isAllowed $=\mathrm{y}($ Acceso 11 de abril de 2020) 
Calveiro, P. (2012). Violencias de Estado y la guerra antiterrorista y la guerra contra el crimen como medios de control global. Siglo XXI.

Cámara de Apelaciones de Comodoro Rivadavia. (2009). Fallo Expediente 24.661. "PIERRE Pedro Valentín y otro s/inc.competencia y prescripción" FUNDAMENTOS- JF. R. Grande.- 5.

Cámara Nacional de Apelaciones en lo Criminal y Correccional Federal de la Capital $\begin{array}{llll}\text { Federal. } & \text { (1985). Sentencia }\end{array}$ https://www.mpf.gob.ar/lesa/jurisprudencia/sentencia-del-juicio-a-loscomandantes-causa-1384/ (Acceso 11 de abril de 2020)

Cámara Nacional de Casación Penal - Sala I. (2009). Fallo "PIERRE Pedro Valentín y otro s/inc.competencia y prescripción."

Cardoso, O. R., Kirschbaum, R., \& Van Der Kooy, E. (1992). Malvinas La Trama Secreta. Planeta.

Centro de Ex Combatientes Islas Malvinas La Plata. (2011). Recurso Extraordinario Federal.

Centro de Ex Combatientes Islas Malvinas La Plata. (2015). Petición P 460-15 CENTRO EX COMBATIENTES ISLAS MALVINAS LA PLATA.

Centro de Ex Soldados Combatientes en Malvinas de Corrientes. (n.d.). Listas de muertos y desaparecidos en acción. https://www.cescem.org.ar/excombatientes/listas/muertos/introduccion.html (Acceso 11 de abril de 2020)

CIDH. (1992). Informe $28 / 92$. http://www.cidh.oas.org/annualrep/92span/Argentina10.147.htm (Acceso 11 de abril de 2020)

CIDH. (2014). Derecho a la Verdad en América. http://www.oas.org/es/cidh/informes/pdfs/Derecho-Verdad-es.pdf (Acceso 11 de abril de 2020)

CIJ. (n.d.). Descripción general de los juicios en la Argentina. Retrieved April 3, 2020, from https://www.cij.gov.ar/lesa-humanidad.html (Acceso 11 de abril de 2020) 
Comisión de Análisis y Evaluación de las Responsabilidades Políticas y Estratégico Militares en el Conflicto del Atlántico Sur. (1983). Informe Final ("Rattenbach”). https://www.casarosada.gob.ar/pdf/InformeRattenbach/01-InformeFinal.pdf

(Acceso 11 de abril de 2020)

Comisión de Evaluación de las Operaciones en las Islas Malvinas. (1982). Informe Calvi. http://archivos.memoriaabierta.org.ar/index.php/informes-de-la-comisi-n-calvi (Acceso 11 de abril de 2020)

Conferencia Interamericana para el Mantenimiento de la Paz y la Seguridad del Continente. (1947). Tratado Interamericano de Asistencia Recíproca (TIAR). https://www.oas.org/juridico/spanish/tratados/b-29.html (Acceso $11 \mathrm{de}$ abril de 2020)

Cortázar, J. (1979). Un tal Lucas. Proyecto Espartaco. https://ddooss.org/libros/Lucas_Julio_Cortazar.pdf (Acceso 11 de abril de 2020)

Corte Suprema de Justicia de la Nación. (2007). Acordada 4/2007. https://www.economia.gob.ar/concursos/biblio/ACORDADA 4-07 RECURSO EXTRAORDINARIO.pdf (Acceso 11 de abril de 2020)

Corte Suprema de Justicia de la Nación. (2015a). Resolución aclaratoria CSJ 101/2012 (48-T) / CS1 RECURSO DE HECHO Taranto, Jorge Eduardo s/ causa 14.969.

Corte Suprema de Justicia de la Nación. (2015b). Resolución CSJ 101/2012 (48-T) RECURSO DE HECHO Taranto, Jorge Eduardo s/ causa 14.969 del 19 de febrero de 2015.

D’Andrea Mohr, J. L. (1998). El escuadrón perdido. Planeta.

D’Angelo, J. (2019). Una farsa para convertir a las Islas Malvinas en sucursal del negocio con los Derechos Humanos. Perfil. https://www.perfil.com/noticias/opinion/unafarsa-para-convertir-a-las-islas-malvinas-en-sucursal-del-negocio-con-losderechos-humanos.phtml (Acceso 11 de abril de 2020)

De la Torre, R. (1997). La comunicación intersubjetiva como fundamento de objetivación etnográfica. Comunicación y Sociedad, 149-173.

Decreto 200/12. (2012). http://servicios.infoleg.gob.ar/infolegInternet/anexos/195000199999/195440/norma.htm (Acceso 11 de abril de 2020) 
Decreto 503/15. (2015). http://servicios.infoleg.gob.ar/infolegInternet/anexos/245000249999/245527/norma.htm (Acceso 11 de abril de 2020)

Decreto 700/82. (1982). http://servicios.infoleg.gob.ar/infolegInternet/anexos/320000324999/322770/norma.htm (Acceso 11 de abril de 2020)

Despouy, L. (2014). La contribución de la República Argentina a la prohibición de la tortura en el sistema universal. Reflexiones desde la experiencia personal. In "Prevenir y Sancionar la Tortura en Argentina a 200 años de su prohibición". Congreso Internacional sobre Tortura y Otros Tratos o Penas Crueles, Inhumanos o Degradantes, Ciudad Autónoma de Buenos Aires: Defensoría General de la Nación.

Díaz Ledesma, L. G., Giordano, C. J., Migliorati, M. A., Otrocki, L., Palazzolo, F., Souza, M. S., Vestfrid, P., \& Vidarte Asorey, V. (2013). Hacia la tesis. Itinerarios conceptuales y metodológicos para la investigación en comunicación. Instituto de Investigaciones en Comunicación (IICOM).

Equipo de Relevamiento y Análisis de los Archivos del Ejército. (2016a). Malvinas II.

Equipo de Relevamiento y Análisis de los Archivos del Ejército. (2016b). Relevamiento Ejército.

Esteban, E. (1993). Iluminados por el fuego. Sudamericana.

Fair, H. (2014). Las reformas pro-mercado en la Argentina. Un análisis socio-hitórico de las políticas económicas del período 1976-1983. Desenvolvimento Regional Em Debate, 132-164. https://dialnet.unirioja.es/descarga/articulo/5443953.pdf (Acceso 11 de abril de 2020)

Feinmann, J. P. (2005). De la vanguardia a la prehistoria. Página/12. https://www.pagina12.com.ar/diario/contratapa/13-45810-2005-01-08.html (Acceso 11 de abril de 2020)

Feinmann, J. P. (2006). La sangre derramada. Booklet.

Ferrarotti, F. (1981). Vite di periferia. Mondatori.

Foucault, M. (2000). Un diálogo sobre el poder y otras conversaciones. Alianza Editorial S.A. 
Foucault, M. (2008). El poder psiquiátrico. Fondo de Cultura Económica.

Foucault, M. (2014a). El poder, una bestia magnífica: Sobre el poder, la prisión y la vida. Siglo Veintiuno Editores.

Foucault, M. (2014b). Vigilar y castigar: Nacimiento de la Prisión. Siglo Veintiuno Editores.

Gamarnik, C., \& Guembre, M. L. (2018). El regreso de los soldados de las islas Malvinas: la trama del ocultamiento.

Giordano, C. J. (2017). Malvinas y Atlántico Sur: estudios sobre soberanía. La UNLP sobre la guerra y la posguerra de Malvinas (C. J. Giordano (Ed.)). Instituto Malvinas y Universidad Nacional de La Plata (UNLP).

Giordano, C. J., Guerrero Iraola, J., \& Alonso, E. (2018). Malvinas en clave de Derechos Humanos: experiencias, desafíos y tensiones. Editorial de la Cámara de Diputados de la Provincia de Buenos Aires (C. J. Giordano, J. Guerrero Iraola, \& E. Alonso (Eds.)). Facultad de Ingeniería UNLP.

Giordano, C. J., Lino, S., Gratti, A. L., Castaño, M. M., \& Guidone, C. (2012). Narrar y escuchar Malvinas. 30 años de posguerra. Editorial de la Universidad Nacional de La Plata (EDULP).

Giordano, C. J., Mendoza Padilla, M., \& Otrocki, L. (2011). Cuestiones sobre identidad y memoria. Ediciones de Periodismo y Comunicación (EPC).

González Warcalde, L. S. (2012). Dictamen S.C. T.101 L. XLVIII.

Guerrero Iraola, J. (2019a). Malvinas: el único negocio para ciertos sectores es la impunidad. Perfil. https://www.perfil.com/noticias/opinion/opinion-jeronimoguerrero-iraola-malvinas-el-unico-negocio-para-ciertos-sectores-es-laimpunidad.phtml (Acceso 11 de abril de 2020)

Guerrero Iraola, J. (2019b). Torturas en Malvinas: en favor de la Justicia o cómplice de los hechos. Perfil. https://www.perfil.com/noticias/opinion/opinion-jeronimoguerrero-iraola-torturas-en-malvinas-en-favor-de-la-justicia-o-complice-de-loshechos.phtml (Acceso 11 de abril de 2020)

Guerrero Iraola, J., \& Giordano, C. J. (2016). Progresividad o regresividad en materia de 
derechos económicos, sociales y culturales. Claves para pensar Nuestramérica (2015-2019). Questión, 90-97.

Hammersley, M., \& Atkinson, P. (1995). Ethnography: Principles in Practice.

Infobae. (2019). Sentido homenaje a los veteranos de Malvinas en el acto por el Día del Ejército. https://www.infobae.com/politica/2019/05/29/sentido-homenaje-a-losveteranos-de-malvinas-en-el-acto-por-el-dia-del-ejercito/ (Acceso 11 de abril de 2020)

Junta Militar. (1980). Documentos básicos y bases políticas de las Fuerzas Armadas para el Proceso de Reorganización Nacional. http://www.bnm.me.gov.ar/giga1/documentos/EL000162.pdf (Acceso 11 de abril de 2020)

Juzgado Federal de Río Grande. (2009). Fallo "Pierre Pedro Valentín s/ Delito de acción pública."

Juzgado Federal de Río Grande. (2020). Procesamientos Miguel Ángel Garde, Belisario Gustavo Affranchino Rumi, Eduardo Luis Gassino, y Gustavo Adolfo Calderini.

Kohan, M. (2014). El país de la guerra. Eterna cadencia editora.

La Nación. (2018a). Malvinas: absurda persecución. https://www.lanacion.com.ar/opinion/obras-que-corrigen-remoras-delpasadomalvinas-absurda-persecucion-nid2148843 (Acceso 11 de abril de 2020)

La Nación. (2018b). Malvinas: otro uso espurio de los derechos humanos. https://www.lanacion.com.ar/editoriales/malvinas-otro-uso-espurio-de-losderechos-humanos-nid2205083 (Acceso 11 de abril de 2020)

La Nación. (2020). La Guerra de las Malvinas y los derechos humanos. https://www.lanacion.com.ar/editoriales/la-guerra-de-las-malvinas-y-los-derechoshumanos-nid2342338 (Acceso 11 de abril de 2020)

Ley 17.531. (n.d.). http://servicios.infoleg.gob.ar/infolegInternet/anexos/1500019999/16537/norma.htm (Acceso 11 de abril de 2020)

Ley 23.492. (n.d.). http://servicios.infoleg.gob.ar/infolegInternet/anexos/2000024999/21864/norma.htm (Acceso 11 de abril de 2020) 
Ley 23.521. (n.d.). http://servicios.infoleg.gob.ar/infolegInternet/anexos/2000024999/21746/norma.htm (Acceso 11 de abril de 2020)

Ley 24.429. (n.d.). http://servicios.infoleg.gob.ar/infolegInternet/anexos/04999/802/norma.htm (Acceso 11 de abril de 2020)

Ley 25.779. (n.d.). http://servicios.infoleg.gob.ar/infolegInternet/anexos/8500089999/88140/norma.htm (Acceso 11 de abril de 2020)

Leyes, R. (2007). Represión a la izquierda en la provincia argentina de Entre Ríos durante la Revolución de Junio, 1943-1945. Izquierdas (Santiago). https://scielo.conicyt.cl/scielo.php?script=sci_arttext\&pid=S071850492017000100132\#fn18 (Acceso 11 de abril de 2020)

López Noguero, F. (2002). El análisis de contenido como método de investigación. Revista de Educación, 167-179. http://rabida.uhu.es/dspace/bitstream/handle/10272/1912/b15150434.pdf;El (Acceso 11 de abril de 2020)

Lvovich, D. (2009). Sistema político y actitudes sociales en la legitimación de la dictadura militar argentina (1976-1983). Ayer, 275-299. www.jstor.org/stable/41326034 (Acceso 11 de abril de 2020)

Maneiro, M. (2005). Como el árbol talado. Memorias del genocidio en La Plata, Berisso y Ensenada. Ediciones Al Margen.

Marshall, C., \& Rossman, G. (1995). Designing Qualitative Research. Sage.

Memoria Abierta. (n.d.). Reseña y documentos históricos. Retrieved March 29, 2020, from http://www.memoriaabierta.org.ar/materiales/documentos_historicos.html (Acceso 11 de abril de 2020)

Miles, M., \& Huberman, A. (1994). Qualitative Data Analysis. Sage.

Ministerio de Defensa de la República Argentina. (n.d.). Informe del Ministerio de Defensa. https://www.argentina.gob.ar/sites/default/files/informe_malvinas.pdf (Acceso 11 de abril de 2020)

Mitoma, G. (2010). Malik and human rights: Notes on a biography. Biography, 222-441. OEA. (1948). Carta de la Organización de Estados Americanos. 
http://www.oas.org/dil/esp/afrodescendientes_manual_formacion_lideres_anexos.p df (Acceso 11 de abril de 2020)

Pejlatowicz, P. (2013). Justificaciones argentinas en los albores del enfrentamiento por las islas Malvinas. In E. Buis \& L. Giosa (Eds.), Derecho internacional y conflictos armados: aportes para una comprensión histórica, normativa y práctica. (pp. 307314). Universidad Nacional del Centro de la Provincia de Buenos Aires.

Perren, J. (2012). Enfoque biográfico: aproximaciones teóricas, herramientas metodológicas y potencialidad en los estudios regionales. Revista Argentina de Humanidades y Ciencias Sociales, 1-29.

Pestanha, F. J. (n.d.). Las disputas por Malvinas. http://www.fundacionmalvinas.org/media/attachments/texto-malvinero-defrancisco-pestanha_1011_1.doc (Acceso 11 de abril de 2020)

Punch, K. (1998). Introduction to Social Research: Quantitative and Qualitative Approaches. Sage.

Raffin, M. (2018). La imbricación vida-poder en el pensamiento de Michel Foucault y Giorgio Agamben. Cuestiones De Filosofía, 117-137. https://revistas.uptc.edu.co/index.php/cuestiones_filosofia/article/view/8309 (Acceso 11 de abril de 2020)

Ramos Padilla, A. (2011). Crímenes de Lesa Humanidad en la Argentina. De la cultura de la impunidad a la inexorabilidad del juicio y castigo. FDJ Editores.

Rattenbach, A. B. (2014). Informe Rattenbach. In A. Romero (Ed.), Malvinas. Un anacronismo colonial (pp. 179-194). Honorable Cámara de Diputados de la Nación.

Romero, A. (Ed.). (2014). Malvinas. Un anacronismo colonial. Honorable Cámara de Diputados de la Nación.

Rouquié, A. (2017). El Siglo de Perón. Edhasa.

Saltalamacchia, H. (1992). La historia de vida. Ediciones Cijup.

Salvioli, F. (1996). Relaciones internacionales, derechos humanos y educación para la paz. En: "Direitos Humanos, a promessa do século XXI. Universidade Portucalense.

Sánchez Mariño, H. (2018). Los caranchos de nuestros muertos y heridos de Malvinas. 
Infobae. https:/www.infobae.com/opinion/2018/07/25/los-caranchos-de-nuestrosmuertos-y-heridos-de-malvinas/ (Acceso 11 de abril de 2020)

Sapriza, G. (1998). Identidades populares. La historia de un pueblo obrero (1890-1913). CIDS - Institut Français d'études Andines. IFEA - Anthropos, 43-64.

Sarabia, B. (1986). Documentos personales: Historias de vida (M. García, J. Ibáñez, \& F. Alvira (Eds.); El análisi). Alianza Universitaria.

Scott, J. (1900). A Matter of Record: Documentary Sources in Social Research. Polity Press.

Seoane, D. (2015). Malvinas: Una cuestión imprescriptible. Los vejámenes contra soldados a la luz del derecho penal internacional. http://justicialegitima.org/noticias/malvinas-una-cuestion-imprescriptible-pordalila-seoane-633.html (Acceso 11 de abril de 2020)

Szczepanski, J. J. (1979). El método biográfico. Revista de Sociología, 231-256.

Tesch, R. (1990). Qualitative research: Analysis types and software tools. Falmer.

Tondini, B. (2007). Malvinas. Historia, aspectos jurídicos y económicos. Eumed.net. http://www.eumed.net/libros-gratis/2007b/278/47.htm (Acceso 11 de abril de 2020)

Vassel, P. (2007). Corrientes en Malvinas. Ediciones Al Margen.

Verbitsky, H. (1988). Medio siglo de proclamas militares. Colección "Presente. Editora/12.

Walsh, R. (1977). Carta abierta de Rodolfo Walsh a la Junta Militar. https://www.cels.org.ar/common/documentos/CARTAABIERTARODOLFOWAL SH.pdf (Acceso 11 de abril de 2020)

Zabala, M. E. (2012). Hacer estudios etnográficos en archivos sobre hechos sociales del pasado. La reconstrucción de la trayectoria académica y religiosa de Monseñor Pablo Cabrera a través de los archivos de la ciudad de Córdoba. Tabula Rasa, 265-282. 